Notre Dame Law School

NDLScholarship

Journal Articles

Publications

1997

\title{
The Secret Lives of the Four Horsemen
}

Barry Cushman

Notre Dame Law School, bcushman@nd.edu

Follow this and additional works at: https://scholarship.law.nd.edu/law_faculty_scholarship

Part of the Constitutional Law Commons, Courts Commons, and the Property Law and Real Estate Commons

\section{Recommended Citation}

Barry Cushman, The Secret Lives of the Four Horsemen, 83 Va. L. Rev. 559 (1997).

Available at: https://scholarship.law.nd.edu/law_faculty_scholarship/294

This Article is brought to you for free and open access by the Publications at NDLScholarship. It has been accepted for inclusion in Journal Articles by an authorized administrator of NDLScholarship. For more information, please contact lawdr@nd.edu. 


\title{
ESSAY
}

\section{THE SECRET LIVES OF THE FOUR HORSEMEN}

\author{
Barry Cushman*
}

Difficile est saturam non scribere.

- Juvenal, Saturae, I, 30.

“ utlined against red velvet drapery on the first Monday of October, the Four Horsemen rode again. In dramatic lore they are known as Famine, Pestilence, Destruction, and Death. These are only aliases. Their real names are Van Devanter, McReynolds, Sutherland, and Butler. They formed the crest of the reactionary cyclone before which yet another progressive statute was swept over the precipice yesterday morning as a packed courtroom of spectators peered up at the bewildering panorama spread across the mahogany bench above."

Or so Grantland Rice might have written, had he been a legal realist. For more than two generations scholars have seen the Four Horsemen as far right, reactionary, staunchly conservative apostles of laissez-faire and Social Darwinism. ${ }^{2}$ And with good reason. One need only read opinions such as those in Adkins $v$. Children's Hospital and Morehead v. Tipaldo ${ }^{4}$ Railroad Retirement Board v. Alton Railroad ${ }^{5}$ and Ribnik v. McBride, ${ }^{6}$ Hammer v. Dagenhart, and Carter Coal, ${ }^{8}$ and the dissents in such cases as Nebbia, ${ }^{9}$ Blaisdell, ${ }^{10}$ the Gold Clause Cases, ${ }^{11}$ and the Wagner Act Cases $^{12}$ to understand why. One can hardly avoid coming away from these and other decisions with the impression that these were men fanatically devoted to property rights and callously indifferent to the commonweal.

* Associate Professor of Law, St. Louis University School of Law. B.A., Amherst College; M.A., J.D., Ph.D., University of Virginia. Thanks to Michal Belknap, Patrice Cushman, Jack Goldsmith, John Harrison, Mike Klarman, Bill Nelson, and Ted White for enduring earlier drafts, and to Todd Ammerman, Heather Hart, and Andrew Krueger for helpful research assistance. An earlier and abbreviated version of this essay was presented at the 1996 Annual Meeting of the Pacific Coast Branch of the American Historical Society. 
Here and there one finds shreds of biographical evidence suggesting that something like the milk of human kindness may have flowed in parsimonious quantities through their veins. We discover that Sutherland's legislative career saw him support the eight-hour day, the Employers' Liability Act, the Pure Food and Drugs Act, the Hepburn Rate Bill, the Children's Bureau, the Seaman's Act of 1915, Postal Savings Banks, free coinage of silver, and the 1896 presidential candidacy of the populist William Jennings Bryan. ${ }^{13}$ We even find Sutherland in the vanguard of the struggle for women's suffrage ${ }^{14}$ and a system of workmen's compensation for the employees of interstate carriers. ${ }^{15}$ We read of Butler's leadership in the fight for workmen's compensation in his home state of Minnesota ${ }^{16}$ of his efforts on behalf of the federal government in prosecuting Swift, Armour, and other large meatpackers for violations of the Sherman Antitrust Act; of his special prosecution of Midwest millers for selling flour bleached with nitrogen peroxide in violation of the Pure Food and Drugs Act; ${ }^{17}$ and of his success in saving the Canadian government "huge sums of money in valuation proceedings against some of the western railroads." ${ }^{\prime \prime 18} \mathrm{We}$ are told of McReynolds' role as an avid trustbuster for Presidents Taft and Wilson, of his environmentalism, and of his generosity toward charitable causes. ${ }^{19}$ We learn of Van Devanter's reputed sensitivity to the plight of the Native American ${ }^{20}$ But such paltry gestures of concern for the underdog have been far from sufficient to rebut Fred Rodell's charge that their jurisprudence was driven by "their basic and bone-deep Hamiltonian empathy with the wellto-do ...."21

When one dips a bit deeper into the U.S. Reports, however, one discovers some startling data. One finds the Four Horsemen actually supporting liberal case outcomes. At first one is inclined to dismiss these cases as mere aberrations, attributable perhaps to the dull Horsemen's inability to recognize when the liberals were pulling the wool over their eyes. But the cases continue to mount until the sheer volume is so immense as to point irrefragably to only one conclusion: The Four Horsemen were themselves closet liberals. It appears that they struck a reactionary pose in celebrated cases in order to retain the good graces of the conservative sponsors to whom they owed their 
positions and whose social amenities they continued to enjoy, while in legions of low-profile cases they quietly struck blows for their own left-liberal agendas. In this way, it seems, the Horsemen could continue to enjoy access to the corridors of power and influence and the hospitality of the most fashionable Washington salons, while at the same time working surreptitiously to undermine the very causes that their conservative patrons held most dear. Theirs, then, is not a simple story of handmaidens of the industrial and financial elite. It is instead a tale of luxury and deceit.

\section{I.}

If there's anything a good conservative can't stand, it's a taxand-spend liberal. One immediately becomes suspicious of the sincerity of the Four Horsemen's devotion to the conservative cause when one recognizes the extent of their complicity in a veritable orgy of revenue enhancement. Throughout their tenures on the high bench, the Four Horsemen repeatedly sustained the power of big government to take other people's money. ${ }^{22}$ In case after case they turned back assaults on the hated federal income tax. ${ }^{23}$ They upheld scores of taxes on business in the face of every conceivable manner of constitutional challenge. ${ }^{24}$ As traitors to their class they also cheerfully acquiesced in numerous confiscations of inherited wealth, voting to uphold imposition of various state and federal estate, gift, inheritance and succession taxes. ${ }^{25}$ The most important of these decisions was the 1927 case of Florida $v$. Mellon, ${ }^{26}$ in which the state challenged a section of the federal estate tax granting a credit for state inheritance taxes paid. The death-tax free state of Florida, the emergent mecca for snowbirds fleeing the severe winters and steep inheritance taxes of the northern states, charged that the section in question constituted "an invasion of the sovereign rights of the state and a direct effort on the part of Congress to coerce the state into imposing an inheritance tax and to penalize it and its property and citizens for the failure to do so."27 Each of his fellow Horsemen joined Sutherland's opinion rebuffing Florida's attack. "If the act interferes with the exercise by the state of its full powers of taxation or has the effect of removing property from its reach which otherwise would be 
within it," remarked Sutherland, "that is a contingency which affords no ground for judicial relief. The act is a law of the United States made in pursuance of the Constitution and, therefore, the supreme law of the land, the constitution or laws of the states to the contrary notwithstanding. Whenever the constitutional powers of the federal government and those of the state come into conflict, the latter must yield."2s

Six years later Paul and Elizabeth Brandeis Raushenbush, authors of the Wisconsin state unemployment statute, were visiting Justice Brandeis at his summer cottage in Chatham, Massachusetts. During a typically lighthearted Brandeis family chat, Paul groused that concerns over placing their own businesses at a competitive disadvantage had kept other states from following Wisconsin's lead. Brandeis' reply was instantaneous. "Have you considered the case of Florida v. Mellon?"29 he asked. What Brandeis was suggesting, as he later made explicit in his behindthe-scenes campaign for enactment of the Wagner-Lewis social security bill, was that the federal government could use its taxing power to prod the states into enacting unemployment compensation programs in precisely the way that the provision upheld in Florida v. Mellon had encouraged states to enact state inheritance taxes. Congress could simply impose a uniform national payroll tax on all employers, the proceeds to be paid into a federal unemployment insurance fund. Employers would be allowed a credit against the federal tax for any amount paid into a comparable insurance plan established by their own states. The states would presumably respond as they had to the enactment of the federal estate tax credit at issue in Florida $v$. Mellon-by enacting their own unemployment compensation plans. The race to the bottom would thus be avoided through a scheme of cooperative federalism. Working from the constitutional blueprint suggested by Brandeis, Paul Raushenbush and Tom Eliot prepared a draft which formed the basis of what became the unemployment insurance provisions of the Social Security Act of $1935 .{ }^{30}$ Both the bill's principal Senate sponsor and government counsel defended its constitutionality on the authority of Florida v. Mellon, ${ }^{31}$ and Sutherland's handiwork was central to Justice Cardozo's opinion upholding the Act in Steward Machine Co. v. Davis. ${ }^{32}$ 
Sutherland and Van Devanter could not afford to be seen supporting so liberal a result in such a high profile case. They had already pushed the envelope by silently acquiescing in Cardozo's opinion upholding the old-age pension provisions of the Act. ${ }^{33}$ They had to appear in the opposing column in the newspaper reports, even though they could be sure that few would actually read what they recorded in dissent. Accordingly, Sutherland fashioned an opinion in which he weakly objected to sections of the Act requiring the states to pay the proceeds from their payroll taxes into the federal treasury, to be withdrawn only by state agencies approved by the federal board. The imposition wrought by these easily revisable and relatively unimportant administrative provisions, he lamely maintained, did not "comport with the dignity of a quasi-sovereign state." 34 But one could tell that his heart was not in the effort, for even as he nitpicked at the Act's periphery he swallowed whole its core. "With most of what is said in the opinion just handed down, I concur," he confessed. ${ }^{35}$

I agree that the payroll tax levied is an excise within the power of Congress; that the devotion of not more than $90 \%$ of it to the credit of employers in states which require the payment of a similar tax under so-called unemployment-tax laws is not an unconstitutional use of the proceeds of the federal tax; that the provision making the adoption by the state of an unemployment law of a specified character a condition precedent to the credit of the tax does not render the law invalid. I agree that the states are not coerced by the federal legislation into adopting unemployment legislation. The provisions of the federal law may operate to induce the state to pass an unemployment law if it regards such action to be in its interest. ${ }^{36}$

"But that," he wrote, echoing his opinion of a decade earlier, "is not coercion." At the end of his career Sutherland could no longer bring himself to the heights of duplicity manifest in McReynolds' and Butler's Tenth Amendment rants against the whole idea of federal social security ${ }^{38}$ His paternity was undeniable. It is for his opinion in Florida $v$. Mellon and all that it spawned that Sutherland is known to this day among the conservative cognoscenti as "the tax collector for the welfare state." 
Of course, if you're going to have a welfare state you have to be able to spend the money you collect. Here again Sutherland and company laid the constitutional foundation for the Great Society. Massachusetts v. Mellon and Frothingham v. Mellon ${ }^{39}$ involved constitutional challenges to the Sheppard-Towner Maternity Aid Act of 1921, which established a federal grant-in-aid program for the reduction of maternal and infant mortality. Under the statute, Congress appropriated funds to be disbursed to states that established qualifying programs for the promotion of maternal and infant health. The Commonwealth of Massachusetts attacked the statute on several grounds, alleging that the appropriations in support of the program were for local rather than national purposes and therefore beyond the powers of Congress; that they were an attempt to induce the states to yield a portion of their reserved sovereign rights upon pain of losing the share of the appropriation to which they would otherwise be entitled, and therefore an invasion of the powers of local self-government reserved to the states under the Tenth Amendment; and that the burden of the appropriations fell unequally upon the several states, and rested largely upon such industrial states as Massachusetts. Frothingham, a citizen of Massachusetts, complained that the appropriations would increase the burden of future federal taxation and thereby, under the guise of taxation, take her property without due process of law.

Sutherland, flanked by each of his fellow equestrians, made short work of each of these contentions. First, Massachusetts had presented the Court with no justiciable controversy. The state could not, as parens patriae, institute judicial proceedings to protect citizens of the United States from the operation of federal statutes. ${ }^{40}$ Nor could the state sue to enjoin the statute's execution on its own behalf, for such a suit presented a question "political and not judicial in character, and therefore not a matter which admits of the exercise of the judicial power." though he dispatched Massachusetts' complaints on justiciability grounds, he could not entirely conceal his contempt for the state's whiny effort to thwart the program with the Tenth Amendment. "[T]he powers of the State are not invaded," he insisted, "since the statute imposes no obligation but simply ex- 
tends an option which the State is free to accept or reject." ${ }^{92}$ "[N]othing has been done and nothing is to be done without [the States'] consent." ${ }^{\prime 3}$ The statute did not "require the States to do or to yield anything. If Congress enacted it with the ulterior purpose of tempting them to yield, that purpose may be effectively frustrated by the simple expedient of not yielding." Sutherland dispatched Ms. Frothingham's complaint with equal alacrity ${ }^{45}$ Her interest in the moneys of the federal treasury, shared with millions of others, was so "minute and indeterminable" as to deny her standing to challenge the appropriation. ${ }^{45}$

"In the Maternity Act cases," Benjamin Wright later observed, "the Court had refused to review the constitutionality of national expenditures for a purpose that was clearly within the domain of the powers reserved to the states. ${ }^{947}$ These decisions, remarked Carl Swisher, "indicated that, whether or not Congress had the constitutional power to make grants-in-aid of the types being made, there was no manner of bringing about a judicial determination that the acts were unconstitutional." "Neither a state nor an individual taxpayer could challenge the validity of such a use of moneys in the courts. ${ }^{.49}$ Henceforth, observed the always insightful Edward Corwin, "so long as Congress has the prudence to lay and collect taxes without specifying the purposes to which the proceeds from any particular tax are to be devoted, it may continue to appropriate the national funds without judicial let or hindrance."so "Thus," wrote Wright, "the spending of billions of dollars in civilian relief, and in the building of public works was beyond the range of constitutional litigation." ${ }^{11}$ Indeed, "the principal way in which the Court sustained the New Deal measures was by refusing to pass upon the validity of the spending power." 52

Perhaps you will say that Sutherland's opinion in Frothingham merely reflects his genuine concern for the foundational principles of separation of powers. ${ }^{53}$ Perhaps the liberation of the spending power wrought by his hands was merely incidental, an unintended consequence of his fidelity to axioms of governmental structure. Perhaps. But somehow its seems more likely that he and his fellow Horsemen anticipated, perhaps only unconsciously (for they were unconscious for a good bit of the decade), that this opinion would lay the foundation for the luxu- 
riation of a hegemonic class of social welfare bureaucrats. ${ }^{54}$ This is undoubtedly why observers in the courtroom that day witnessed Van Devanter giggling uncontrollably as Sutherland read his opinion from the bench. ${ }^{5 s}$

\section{II.}

Economic royalists have long railed against wasteful regulation of business, maintaining that government meddling is a tremendous drag on economic expansion. But if vibrant growth required getting government off the backs of the people, the Four Horsemen were repeatedly guilty of piling on instead. They upheld a simply enormous array of state police power regulations..$^{56}$ They sustained extensive state supervision of the business operations $s^{57}$ and of the rates charged ${ }^{38}$ by enterprises impressed with a public interest. They had turned back dozens of obscure Contracts Clause challenges before their celebrated dissents in Blaisdell. ${ }^{59}$ Williamson v. Lee Optical Co. ${ }^{60}{ }^{\text {generally }}$ thought to represent the modern Court at its most deferential, involved an Oklahoma statute making it unlawful for anyone other than a licensed optometrist or ophthalmologist to fit lenses to a face, or to duplicate or replace lenses without a written prescription from a licensed optometrist or ophthalmologist. Oklahoma opticians cried foul, but the Justices rejected their due process and equal protection claims. The principal authority on which the Williamson Court relied was Roschen $v$. Ward ${ }^{61}$ in which all Four Horsemen had joined the Court's opinion upholding a New York statute making it unlawful to sell eyeglasses at retail in any store unless a duly licensed physician or optometrist was in charge and in personal attendance. "Of course we cannot suppose the Act to have been passed for sinister motives," wrote Justice Holmes for a unanimous Court. "We cannot say, as the complainants would have us say, that the supposed benefits [of the Act] are a cloak for establishing a monopoly and a pretence." ${ }^{962}$ The Horsemen's repute as guardians of economic liberty dims further when one notes the myriad schemes for occupational licensing in which they acquiesced.$^{63} \mathrm{In}$ fact, less than two years before depriving New York theatergoers of the benefit of a statute regulating resale ticket prices, ${ }^{64}$ McReynolds and company had ducked the price regulation is- 
sue raised by the statute in order to sustain its provisions requiring scalpers to secure licenses. ${ }^{65}$ Perhaps the Horsemen did strike down two regulations of employment agencies for every one they upheld. ${ }^{66}$ But they sustained twice as many statutes regulating bread weight as they invalidated, ${ }^{67}$ leaving Spencerians with at best half a loaf.

The Horsemen were equally headless in their solicitude for the federal leviathan. ${ }^{68}$ They upheld a vast array of national regulatory incursions, including (but not limited to) the Pure Food and Drugs Act, ${ }^{69}$ the Employers' Liability Act ${ }^{70}$ the Safety Appliance Act, ${ }^{71}$ the Packers and Stockyards Act, ${ }^{72}$ and the Grain Futures Act. ${ }^{73}$ They wrote or joined numerous opinions in which the constitutionality of a wide variety of New Deal initiatives was either sustained or assumed. ${ }^{74}$ They voted to uphold more Interstate Commerce Commission ("ICC") orders than you can shake a stick at. ${ }^{75}$ They repeatedly supported Federal Trade Commission ("FTC") efforts to curb unfair trade practices. ${ }^{76}$ They sided with the government or private plaintiffs in dozens of antitrust cases involving all kinds of business, ${ }^{7}$ including railroads ${ }^{78}$ trade associations,${ }^{79}$ and such major manufacturing concerns as Standard Oil, American Tobacco, IBM, International Harvester, ALCOA, Borden, Eastman Kodak, and Shell Oil. ${ }^{80}$

In order to maintain a veneer of evenhandedness amidst this spree of trustbusting, however, the Horsemen occasionally found it necessary to use the Sherman Act to knock a few union heads together as well. ${ }^{81}$ Yet the gobbledygook rationale employed in such anti-union decisions in turn served to legitimate their efforts to thwart various other unionbusting campaigns. In United Mine Workers v. Coronado Coal Co. ${ }^{82}$ for example, Van Devanter and McReynolds joined Chief Justice Taft's opinion reversing a Sherman Act judgment against an organization alleged to have preferred to blow up the company's mine rather than see it operated on a non-union basis. "Coal mining is not interstate commerce, and the power of Congress does not extend to its regulation as such," Taft asserted. ${ }^{83}$

"The making of goods and the nining of coal are not commerce, nor does the fact that these things are to be afterwards shipped or used in interstate commerce, make their production 
a part thereof." Obstruction to coal mining is not a direct obstruction to interstate commerce in coal, although it, of course, may affect it by reducing the amount of coal to be carried in that commerce. ${ }^{84}$

In order for a conspiracy to be actionable under the antitrust law, Taft maintained, "the intent to injure, obstruct or restrain interstate commerce must appear as an obvious consequence of what is to be done, or be shown by direct evidence or other circumstances." The record supplied no such proof of intent. This was a "local" strike, beyond the reach of federal law. ${ }^{85}$ In United Leather Workers Int'l Union v. Herkert \& Meisel Trunk Co., ${ }^{86}$ McReynolds and Sutherland joined Taft's opinion holding that a strike for a closed shop, conducted by means of illegal picketing and intimidation, did not violate the Sherman Act. The strike was admittedly designed to prevent the manufacture of goods to be shipped in interstate commerce. Yet there was no evidence that the strikers had sought to interfere with the transport or sale of goods once they had been manufactured. A mere hope that the decline in sales would induce the company to yield was insufficient.

[T] he mere reduction in the supply of an article to be shipped in interstate commerce, by the illegal or tortious prevention of its manufacture, is ordinarily an indirect and remote obstruction to that commerce. It is only when the intent or necessary effect upon such commerce in the article is to enable those preventing the manufacture to monopolize the supply, control its price or discriminate as between its would-be purchasers, that the unlawful interference with its manufacture can be said directly to burden interstate commerce. ${ }^{87}$

In Levering \& Garrigues Co. v. Morrin, ${ }^{88}$ each of his fellow Horsemen joined Sutherland's opinion rebuffing an employer's request to enjoin a strike and boycott for a closed shop. The structural steel fabricated and erected by the company in New York City was transported from other states, and the company asserted that the effect of the union's actions was to destroy the company's interstate traffic in steel. Even assuming that to be the case, Sutherland responded, that did not bring the union's behavior within the ambit of the Sherman Act's prohibitions. "[T] he sole aim of the conspiracy was to halt or suppress local 
building operations as a means of compelling the employment of union labor, not for the purpose of affecting the sale or transit of materials in interstate commerce," he wrote. ${ }^{89}$

Use of the materials was purely a local matter, and the suppression thereof the result of the pursuit of a purely local aim. Restraint of interstate commerce was not an object of the conspiracy. Prevention of the local use was in no sense a means adopted to effect such a restraint. It is this exclusively local aim, and not the fortuitous and incidental effect on interstate commerce, which gives character to the conspiracy. If thereby the shipment of steel in interstate commerce was curtailed, that result was incidental, indirect and remote....90

Yet when a member of the Seaman's Union of America complained that he had been unlawfully deprived of employment opportunity by a combination of merchant shipowners, each of his fellow Horsemen joined Sutherland's opinion distinguishing these cases. The shipowners' scheme to control the employment of all seamen on the Pacific Coast ran afoul of the Sherman Act because

the combination and the acts complained of did not spend their intended and direct force upon a local situation. On the contrary, they related to the employment of seamen for service on ships, both of them instrumentalities of, and intended to be used in, interstate and foreign commerce; and the immediate force of the combination, both in purpose and execution, was directed toward affecting such commerce. The interference with commerce, therefore, was direct and primary, and not, as in the cases cited, incidental, indirect and secondary. ${ }^{91}$

By contrast, when union glass blowers and an association of window glass manufacturers entered into an agreement to fix wages and seasonally rotate the labor force between two sets of factories, all Four Horsemen joined the opinion rejecting the government's Sherman Act challenge. ${ }^{92}$

The ingenue will undoubtedly interject, "But Bruce, aren't you being unduly cynical? I mean, gee whiz, it seems like maybe the notion that the internal affairs of local enterprises engaged in production were beyond the reach of the Sherman Act unless intended to restrain interstate commerce might reconcile not only the labor cases, but the business antitrust cases as well. ${ }^{93}$ 
The idea that productive activity was generally beyond the reach of federal regulatory authority might explain why, for example, the NIRA, ${ }^{94}$ the $\mathrm{AAA}^{95}$ and the Guffey Coal $\mathrm{Act}^{96}$ fell, while all of those state business taxes survived dormant commerce clause challenges. ${ }^{97}$ The distinction between production and transportation might also help account for the fact that the Horsemen voted to uphold the labor provisions of the Transportation Act of $1920,{ }^{98}$ the Railway Labor Act ${ }^{99}$ and its 1934 Amendments, ${ }^{100}$ and the Wagner Act when applied to businesses engaged in interstate transportation or communication, ${ }^{101}$ yet voted to invalidate the NLRA as applied to local manufacturing concerns. ${ }^{102}$ Maybe it even helps to explain why Van Devanter voted to uphold Illinois' Child Labor Act ${ }^{103}$ while voting to invalidate federal child labor laws." ${ }^{104}$

To this I have two responses. First, stop calling me Bruce. Second, perhaps you didn't get the word, grasshopper, but we are all realists now. Arthur Schlesinger taught us long ago that federalism is simply the manipulable rallying cry of embittered political losers. ${ }^{105}$ But let us indulge your flatulent hypothesis. How would you explain, for starters, McReynolds and Butler's subsequent concurrence in decisions applying the Wagner Act to entities engaged in local production? ${ }^{106}$ Stare decisis? Come now. ${ }^{107}$ Surely Lochner ${ }^{108}$ supplied adequate precedent to justify striking down all of those working hours statutes they voted to uphold? ${ }^{109}$ And isn't it interesting that they voted to strike down the minimum wage, ${ }^{110}$ so vigorously opposed by Sutherland's pals in the feminist camp, ${ }^{11}$ while voting to uphold every other variety of wage payment statute designed to protect workers from overreaching employers? 112 $^{12}$

Moreover, how does your federalism thesis explain the Horsemen's pro-worker stance in a legion of Federal Employers' Liability Act and Federal Safety Appliance Act cases ${ }^{113}$ in which they often strained to find that the injured plaintiff was engaged in interstate commerce? ${ }^{114}$ Here the contrast between two particular cases is instructive. The plaintiff in the 1919 case of Philadelphia, Baltimore \& Washington R.R. v. Smith ${ }^{15}$ was a cook assigned to a "camp car," whose duty it was to prepare meals for a crew of bridge carpenters who lived on the car and repaired railroad bridges for the company. The cook, injured 
while whipping up cuisine for the carpenters, sought recovery under the FELA. Van Devanter and McReynolds joined the Court's opinion upholding judgment for the plaintiff. The bridge carpenters were engaged in interstate commerce because they were maintaining instrumentalities of such commerce, and the cook, by virtue of the assistance he rendered to the carpenters, was similarly engaged in such commerce. A quarter century later, however, the "Roosevelt Court" would hold that a cook who prepared and served meals to maintenance-of-way employees of an interstate railroad pursuant to a contract between his employer and the railroad company was not "engaged in commerce" within the meaning of the Fair Labor Standards Act." ${ }^{116}$ This application of the "too many cooks" principle opened new frontiers in the domain of gastronomic jurisprudence.

I suppose that the Horsemen might have been able to pass off their votes to sustain workmen's compensation statutes as probusiness efforts to control and regularize the cost of industrial accidents. ${ }^{117}$ But the diligent auditor would not be so easily hoodwinked. For this would not explain why they so often supported injured workers in contested workmen's compensation cases. ${ }^{118}$ Nor would it account for their many pro-plaintiff decisions in tort litigation involving injured employees, ${ }^{119}$ in which they routinely upheld statutes abrogating the unholy trinity of common law defenses: contributory negligence, assumption of risk, and the fellow servant rule. ${ }^{120}$ Add to this their bleedingheart record in tort litigation generally, ${ }^{121}$ and it is little wonder that the Horsemen were the secret darlings of the trial lawyers.

III.

Sometimes the Four Horsemen liked to relax. One of their favorite ways to unwind was to turn loose convicted criminals on the basis of technicalities. And since Prohibition had deprived them of the right to blow off a little steam over a cocktail, they particularly relished liberating liquor's freedom fighters. Of course, Prohibition wasn't all bad. It had created entrepreneurial opportunities for ethnic minorities who experienced widespread discrimination in such middle-class professions as law, medicine, accounting and teaching. ${ }^{12}$ But if southern and east- 
ern European immigrants were to be economically empowered by the Noble Experiment, convictions would have to be overturned where defendants with names like Gambino ${ }^{123}$ and Lefkowitz ${ }^{124}$ were involved.

Van Devanter and McReynolds had evidenced a predisposition to intervene in such cases as early as 1915. In Rossi $v$. $P_{\text {Pennsylvania }}{ }^{125}$ an Ohio liquor dealer had been convicted of selling liquor in the adjoining Pennsylvania county without a Pennsylvania liquor license. Both Justices joined the Court's opinion reversing the conviction on the ground that the statute, as applied to a sale in interstate commerce, ran afoul of the dormant Commerce Clause. ${ }^{126}$ But it was during the Prohibition era that the Horsemen really hit their stride. Consider, for example, Sgro $v$. United States, ${ }^{127}$ in which a federal officer had obtained a warrant to search the premises of the accused for booze in early July. Under the National Prohibition Act such warrants expired ten days after their issuance. The officer did not get around to searching the premises until late July, but before doing so he returned to the magistrate and had the warrant redated and reissued based upon the original affidavit. The accused was convicted based on evidence obtained during the subsequent search, and on appeal all Four Horsemen voted to overturn the conviction. Over the dissents of Stone and Cardozo, the Court held that the warrant had been invalid-once the original warrant had expired, a new warrant had to be issued based on a new affidavit stating probable cause at that time. If you think this seems picky, consider Grau v. United States. ${ }^{128}$ There a federal officer obtained a warrant to search a private dwelling for evidence of violation of the liquor laws based on an affidavit stating that he had seen people hauling cans commonly used in handling whiskey and what appeared to be corn sugar into the house, and had smelled the odor of cooking mash coming from the place. A search turned up a still and 350 gallons of whiskey, which were placed in evidence at trial. With all Four Horsemen joining the opinion, the Court, again over the dissents of Stone and Cardozo, reversed the convictions. The pertinent provision of the Prohibition Act permitted issuance of warrants to search private dwellings only if there was probable cause to believe that the dwelling was being used for the unlaw- 
ful sale of liquor. Here the affidavit stated facts alleging unlawful manufacture, but not unlawful sale. Accordingly the warrant was void, and the evidence inadmissible. ${ }^{129}$

McReynolds and Butler continued to wage this fight to the end, even after the Eighteenth Amendment had been repealed. Butler's dissent in Olmstead $v$. United States ${ }^{130}$ would be vindicated in 1937, when the Court overturned a conviction in an alcohol smuggling case. In Nordane $v$. United States, ${ }^{131}$ Butler joined the majority opinion holding that evidence introduced at the defendants' trial had been acquired in violation of the Communications Act of 1934. (In 1939 McReynolds, then the sole remaining Horseman, joined the Court's opinion following Nordane and overturning convictions for conspiracy to use the mails to defraud, which were obtained on the basis of evidence acquired through wiretaps in violation of the Communications Act. This came as a great relief to named defendants Alfred and Joseph Weiss, as well as to their co-defendants, Messrs. Berger, Spitz, Messman, Goldstein, and Krupp. $\cdot{ }^{132}$ )

The Horsemen managed to make this subversive assault on temperance somewhat more palatable by at least occasionally voting to extend its benefits to rum runners of Northern European heritage as well. In Carroll v. United States ${ }^{133}$ Van Devanter and Butler joined Chief Justice Taft's opinion upholding the warrantless search of the defendant's car, while only McReynolds and Sutherland dissented. "The damnable character of the 'bootlegger's' business should not close our eyes to the mischief which will surely follow any attempt to destroy it by unwarranted methods," McReynolds thundered with Warrenesque righteousness. ${ }^{134}$ The common law authorized arrests for misdemeanors only where the crime had been committed in the officer's presence, and here the federal agents had arrested the defendants upon "mere suspicion." 135 As the arrest had been invalid, the search incident thereto was similarly invalid, and the evidence thereby produced ought to have been suppressed. "If an officer, upon mere suspicion of a misdemeanor, may stop one on the public highway, take articles away from him and thereafter use them as evidence to convict him of crime," McReynolds queried, "what becomes of the Fourth and Fifth Amendments?" ${ }^{1.36}$ In Sorrells v. United States ${ }^{137}$ Van Devanter, Suther- 
land, and Butler joined the majority opinion reversing a conviction on the grounds that the Prohibition Act had not been intended to apply where an otherwise innocent defendant had been lured into a sale of liquor at the instigation of a Prohibition agent, and evidence of entrapment had not been permitted to go to the jury. Each of his fellow Horsemen joined Brother McReynolds' opinion in Nathanson v. United States ${ }^{138}$ invalidating a warrant to search a private dwelling for booze on the grounds that it had been issued based on mere belief and suspicion rather than upon probable cause. And in United States $v$. Chambers ${ }^{139}$ all Four Horsemen joined the Court's opinion holding that all prosecutions for violations of the Prohibition Act pending at the time the Twenty-First Amendment had been ratified had to be dropped..$^{140}$

In light of this sustained use of nit-picking technicalities in their campaign to subvert Prohibition, it probably comes as no surprise that the Horsemen embraced a similar strategy in their efforts to undermine our War on Drugs. In the 1916 case of United States v. Jin Fuey Moy, ${ }^{141}$ for example, both Van Devanter and McReynolds voted to affirm the quashing of an indictment for conspiracy to possess opium and morphine for a nonmedicinal purpose without paying the tax prescribed by the Harrison Narcotics Act, on the ground that the possession conspired for did not fall within the Act's prohibitions. ${ }^{142}$ This was merely a warm-up, however, for the full frontal assault they were to launch against the Act in United States v. Doremus..$^{43}$ There both McReynolds and Van Devanter joined Chief Justice White's dissenting opinion denouncing the Act as an unconstitutional violation of-get this-the Tenth Amendment. The Act was "beyond the constitutional power of Congress to enact," they agreed, reveling in the deployment of the old federalism ruse, because it was "a mere attempt by Congress to exert a power not delegated, that is, the reserved police power of the States." ${ }^{144}$ McReynolds would momentarily vindicate this dissent in Linder $v$. United States ${ }^{145}$ where, joined by each of his fellow Horsemen, he wrote the opinion reversing the conviction of a physician for prescribing morphine and cocaine for a known addict. Referring to the "unfortunate condition" of such addicts, who were "diseased and proper subjects" for the administration 
of drugs in order to relieve conditions incident to addiction, McReynolds opined that regulation of medical practice was a matter reserved to the states and accordingly beyond the power of Congress. ${ }^{146}$ The victory proved to be Pyrrhic, however, and Sutherland, Butler, and McReynolds, again banging the drum of federalism, found themselves in dissent three years later when the Court sustained the Act's constitutionality and affirmed the conviction of Frank Nigro for unlawful sale of an ounce of morphine. ${ }^{147}$ McReynolds and Butler would rail in vain and upon multiple grounds against the conviction for unlawful possession of morphine in Casey v. United States. ${ }^{148}$ McReynolds, joined by Butler, contended that one possessing an unstamped package of morphine could not be presumed to have purchased it unlawfully. ${ }^{149}$ Butler, joining Brandeis, contended that Casey's conviction should have been overturned because the government had entrapped him. ${ }^{\text {150 }}$ And Butler, dissenting alone, opined that the federal government had no power to make mere purchase or possession of morphine a crime. ${ }^{151}$

Though they would lose their war on the War on Drugs, the Horsemen would continue to engage in guerrilla skirmishing with the authorities, taking what few small victories they could. In United States v. Daugherty ${ }^{152}$ each of his fellow Horsemen joined McReynolds' opinion criticizing a fifteen year sentence for three separate sales of cocaine as "extremely harsh" and unjustified by the circumstances disclosed by the record, and remanding the case for reconsideration of the appropriate punishment. ${ }^{153}$ In 1925 they would intervene on behalf of Frank Agnello, who had been convicted of conspiring to sell cocaine in violation of the Act. Agnello had been arrested several blocks from his home and, while he was held in custody elsewhere, the police had conducted a warrantless search of his residence. The search had turned up a can of cocaine, which had been placed in evidence at Agnello's trial. Butler, joined by each of his fellow Horsemen, penned the opinion reversing the conviction on the grounds that "one's house cannot lawfully be searched without a search warrant, except as an incident to a lawful arrest therein." "Belief, however well founded, that an article sought is concealed in a dwelling house," wrote Butler, "furnishes no justification for a search of that place without a warrant." ${ }^{\text {is }}$ The 
Horsemen fired their parting shots at a drug-free America in the 1939 case of Lanzetta v. New Jersey, ${ }^{155}$ where McReynolds joined Butler's opinion striking down on vagueness grounds a statute criminalizing gang membership.

The Horsemen's taste for husbanding the culture of decadence ran to the prurient as well. Though Van Devanter would vote to uphold the Mann White Slave Act against constitutional challenge, ${ }^{156}$ all Four Horsemen would join an opinion reversing the conviction of a man and woman for conspiracy to violate the Act. The couple had admittedly taken an interstate journey whose itinerary included frequent stops for fornication. Yet the Court held that the transported woman was capable neither of committing nor of conspiring to commit any offense under the Act. As the man had conspired with no one else for the forbidden transportation, his conspiracy conviction had to be vacated as well. ${ }^{157}$ Similarly, the bachelor McReynolds would file a lone dissent in United States v. Limehouse, ${ }^{158}$ in which the Court upheld the conviction of a man for mailing "filthy" letters containing language Justice Brandeis described as "coarse, vulgar, disgusting, indecent" and "foul."1s9

Much of the groundwork for this riot of punition-free turpitude had been laid by Van Devanter's quiet acquiescence in the promulgation of the exclusionary rule in Weeks $v$. United States. ${ }^{160}$ But this only begins to tell the story of their softness on crime. The Horsemen took an equally hard line in cases involving the privilege against self-incrimination. In Kercheval $v$. United States, ${ }^{161}$ each of his fellow Horsemen joined Butler's opinion holding that a plea of guilty, withdrawn with leave of the court, was inadmissible at the subsequent trial. In Brown $v$. Mississippi ${ }^{162}$ all Four Horsemen joined in overturning convictions for murder secured on the basis of confessions obtained through police torture. ${ }^{163}$ They similarly joined opinions reversing federal ${ }^{164}$ and state ${ }^{165}$ murder convictions obtained on the basis of confessions elicited under coercive circumstances. And in the 1939 case of Bruno v. United States, ${ }^{166}$ McReynolds voted to overturn a narcotics conviction where the trial court had refused to admonish the jury that the accused's failure to testify in his own defense gave rise to no negative inference. ${ }^{167}$ 
The Horsemen defended the Sixth Amendment rights of confrontation and counsel with equal vigor. Cooke v. United States $^{188}$ involved charges of contempt of court committed by a lawyer outside the courtroom. All Four Horsemen joined the Court's opinion upholding the alleged contemnor's rights to be advised of the charges against him, and to be afforded the opportunity to defend or explain his actions, with the assistance of counsel if he so desired. ${ }^{169}$ Sutherland, and Butler joined the dissenting opinion contending for the right of the accused to be present at a jury viewing of the scene of the crime in Snyder $v$. Massachusetts. ${ }^{170}$ All Four Horsemen joined an opinion strenuously upholding the right of the accused's counsel to attempt to discredit a hostile witness on cross-examination in Alford $v$. United States, ${ }^{171}$ while Van Devanter joined Suthlerland's famous opinion in Powell v. Alabama ${ }^{172}$ holding that the Due Process Clause entitled indigent defendants in a capital case to effective, court-appointed counsel. ${ }^{173}$

The Horsemen were notably vigilant as well in defending the right to trial by an impartial jury of one's peers. In Aldridge $v$. United States, ${ }^{174}$ Van Devanter, Sutherland, and Butler voted to reverse the conviction of a black man charged with the murder of a white policeman on the ground that his attorney had not been permitted to ask potential jurors whether they harbored any racial prejudice that might prevent a fair and impartial verdict. The Horsemen cast numerous votes to overturn convictions of African-Americans where blacks had been systematically excluded from the grand juries that indicted or the petit juries that tried them. ${ }^{175}$ McReynolds, Sutherland, and Butler dissented when the majority abandoned a long-standing precedent that had disqualified federal employees from sitting as jurors in federal trials on the grounds that they were presumptively biased in the government's favor. ${ }^{176}$ Each of his fellow Horsemen joined Sutherland's opinion holding that one prosecuted for reckless driving in the District of Columbia was entithed to be heard by a jury, ${ }^{17}$ and when the Court held that dealing in second-hand property without a license was a petty offense triable without a jury, McReynolds and Butler took exception. ${ }^{178}$ 
The Horsemen also repeatedly intervened when misconduct by the judge, the prosecutor or the community interfered with the defendant's right to a fair trial before an impartial jury. Each of his fellow Horsemen joined Sutherland's opinion in Berger $v$. United States, ${ }^{179}$ holding that the prosecutor's conduct on cross-examination of witnesses and in his argument to the jury had been so egregious as to warrant a new trial. In Moore v. Dempsey, ${ }^{180}$ Van Devanter and Butler joined in reversing an order dismissing a petition for habeas corpus where the defendant's murder trial had been hurried to conviction under the pressure of a mob. ${ }^{181}$ Perhaps the most famous instance of judicial misbehavior occurred at the Espionage Act trial of the noted socialist editor Victor Berger and his associates. Presiding Judge Kenesaw Mountain Landis had made extended remarks impugning the loyalty of German-Americans, including the unforgettable, "If anybody has said anything worse about the Germans than I have I would like to know it so I can use it." On appeal Van Devanter joined the opinion holding that Landis' bias had rendered him unfit to preside over the trial. ${ }^{182}$ But the Horsemen intervened in several lesser-known causes as well. McReynolds dissented in Horning $v$. District of Columbia ${ }^{183}$ which affirmed a criminal conviction in spite of the fact that the trial judge had effectively directed the jury to convict. All Four Horsemen joined the Court's opinion in Quercia v. United States,${ }^{184}$ which overturned a conviction where the jury charge had accused the defendant of prodigious, perjurious prevarication. Each of them also joined the Court's opinion in United States v. Murdock ${ }^{185}$ which, over the dissents of Stone and Cardozo, held that it was reversible error for the trial judge to inform the jury of his view that the accused was guilty beyond a reasonable doubt. In Shields $v$. United States ${ }^{186}$ all Four Horsemen joined in reversing a conviction where the judge had sent written instructions to a deadlocked jury without notice to the accused. All Four Horsemen similarly joined in reversing the conviction for violation of the liquor laws in Tumey $v$. Ohio. ${ }^{187}$ There the state had set up a scheme of compensation for certain judicial officers under which the officer received payment for his services only if the defendant were convicted. This scheme, reminiscent of that established by the Fugitive Slave Act of 
1850 , was held to deny the accused due process of law. ${ }^{188}$ Yet where a trial judge had shortened the sentence a convict had already begun to serve, each of his fellow Horsemen joined Sutherland's opinion upholding the lower court's action against the charge that it usurped the executive's pardoning power ${ }^{189} \mathrm{Com}-$ pare this with Ex parte Grossman, ${ }^{100}$ and it's not difficult to see what's going on. Philip Grossman had flouted an order enjoining violation of the Prohibition Act and had been punished for contempt by a federal district judge. President Harding had commuted Grossman's sentence, and the government contended that permitting presidential pardons for defendants found guilty of criminal contempt unduly impinged upon the independence of the judiciary. All Four Horsemen joined an opinion upholding the President's action..$^{191}$ To top all this off, Butler registered the lone dissent from Cardozo's opinion in Palko v. Connecticut ${ }^{192}$ holding that the prohibition against double jeopardy did not apply to the states.

The behavior of the Four Horsemen in these and other criminal cases ${ }^{133}$ admits of at least two possible interpretations. One interpretation would see these criminal procedure cases as of a piece with some of their decisions in economic substantive due process cases. On this view liberty of contract, the right to be free from unreasonable searches and seizures, and the right against self-incrimination might be seen as manifestations of an integrated vision of "negative" civic liberty. ${ }^{194}$ Perhaps, it might be argued, the Four Horsemen simply did not differentiate economic from noneconomic forms of civil liberty in the way that has come to be seen as obvious and natural in modern liberal thought, and in liberal constitutionalism at least since the Carolene Products footnote. ${ }^{195}$ The more clear-eyed interpretation, however, recognizes (as the Four Horsemen surely did) that this explanation is precisely the kind of ideological pap that bourgeois suckers were likely to swallow hook, line, and sinker. Sutherland had seen clearly the relationship between corporate greed and blue-collar crime in his opinion for the majority in Adkins v. Children's Hospital. ${ }^{196}$ If denial of a living wage might cause women to turn to prostitution, he remarked, it might just as easily turn men to lives of crime. ${ }^{197}$ If they had to invalidate the minimum wage and price regulation in order to retain the 
goodwill of the business elite, the Horsemen could nevertheless help those who turned to crime as a result of capitalist selfishness to do so free of punitive consequences. In this way the necessary costs of their superficially pro-business stance could be quietly and interstitially spread through a permissive posture toward crime. And all of this could be done in the name of liberty.

IV.

While undertaking such vigorous exertions on behalf of the criminals' lobby, the Horsemen apparently thought it best to maintain a low profile in cases in which political and religious mavericks sought the shelter of the First Amendment. Yet even here one detects a concerted if slippery campaign to frustrate the conservative agenda. While Van Devanter and McReynolds had voted to uphold convictions for attempts to obstruct the draft under the Espionage Act, ${ }^{198}$ all Four Horsemen joined the opinion turning back a government attempt to characterize such obstruction as a criminal conspiracy to defraud the United States when the Espionage Act had expired. ${ }^{199}$ In 1925 they joined Justice Sanford's opinion in Gitlow v. California ${ }^{200}$ which, while upholding Gitlow's conviction for criminal anarchism, slyly applied the First Amendment's speech and press guaranties against the states through the Fourteenth Amendment's Due Process Clause, thereby facilitating future intervention on behalf of persecuted dissenters. ${ }^{201}$ This promise was first redeemed in 1927 when, while they voted to uphold Communist Labor Party organizer Anita Whitney's criminal syndicalism conviction, ${ }^{20}$ they joined the very same day an opinion reversing the criminal syndicalism conviction of an organizer for the Industrial Workers of the World. ${ }^{203}$ In 1931 they employed a slightly different diversionary tactic, with McReynolds ${ }^{204}$ and Butler ${ }^{205}$ filing token dissents from the reversal of a conviction for violation of California's law prohibiting the display of red flags, while Van Devanter and Sutherland silently acquiesced in Hughes' opinion for the majority. ${ }^{206}$ While the anti-Semitic McReynolds ${ }^{27}$ and his fellows defended state censorship of a publication devoted to the defamation of Minneapolis Jews in Near $v$. Minnesota ${ }^{208}$ they voted five years later to strike down 
Louisiana's special tax on newspapers of large circulation in Grosjean v. American Press Co. ${ }^{200}$ In 1937 they railed against the reversal of Communist Party organizer Angelo Herndon's conviction for incitement to violent insurrection. ${ }^{210}$ Yet that same term they discreetly voted to overturn the criminal syndicalism conviction of Party member Dirk De Jonge, who had assisted in the conduct of a public meeting held under the auspices of the Party, on the flimsy ground that the troublemaker had advocated no unlawful action at that particular meeting. ${ }^{211}$ While McReynolds, when the sole remaining Horseman, would vote to uphold the flag salute requirement challenged in Minersville School District v. Gobitis, ${ }^{212}$ he would during the same term vote to overturn the conviction of a Jehovah's Witness for breach of the peace and soliciting contributions without a license. ${ }^{213}$ Two years earlier, when Butler had still ridden at McReynolds' side, the two remaining Horsemen had similarly joined the opinion reversing the conviction of a Jehovah's Witness for distribution of pamphlet literature without a license. ${ }^{214}$

This cagey "Look over there!"/ "Your shoe's untied" strategy for accommodating political and religious diversity was complemented by a similarly stealthy jurisprudence of multiculturalism. McReynolds, perhaps best remembered for his infamously bigoted treatment of his Jewish brethren Brandeis and Cardozo, ${ }^{215}$ was joined by Van Devanter and Butler in making up out of whole cloth a right to receive instruction in modern foreign languages in Meyer v. Nebraska. ${ }^{216}$ In Farrington $v$. Tokushige $e^{217}$ each of his fellow Horsemen joined McReynolds' opinion extending the benefits of that right to aliens in Hawaii attending schools in which the primary language of instruction was Japanese. The Horsemen unanimously repelled the monoculturalist Ku Klux Klan's attack on parochial education in Pierce v. Society of Sisters, ${ }^{218}$ while Van Devanter, joined by Sutherland and Butler, wrote the opinion upholding the power of New York to require the Klan to disclose to the secretary of state its governing documents, officer roster and membership list-a requirement from which the Court would shield the NAACP thirty years later. ${ }^{219}$ Van Devanter rejected the Klan's contention that requiring it to make such disclosure while excusing labor unions and other oath-bound organizations from 
such revelations denied the Klan equal protection. The classification was justified, Van Devanter explained, because the Klan, unlike labor unions, had a tendency "to make the secrecy surrounding its purposes and membership a cloak for acts and conduct inimical to personal rights and public welfare"; because it engaged in acts designed " to strike terror into the minds of the people"'; because "its membership was limited to native born, gentile, Protestant whites" and its members took an oath "to shield and preserve "white supremacy"'; and because "it was conducting a crusade against Catholics, Jews, and Negroes and stimulating hurtful religious and race prejudices."'220

America's turn inward after World War I produced a xenophobic immigration policy, and the Four Horsemen cultivated a correspondingly harsh public posture in the celebrated naturalization cases of the period. ${ }^{21}$ They are perhaps best remembered for joining Butler's opinion upholding the preposterous denial of citizenship to forty-nine year old pacifist Rosika Schwimmer on the ground that she would not swear to take up arms in defense of the United States. ${ }^{22}$ Yet peremptory treatment of such liberal darlings as Schwimmer, MacIntosh, ${ }^{223}$ and Bland ${ }^{224}$ provided cover for their campaign to subvert the nation's renascent nativist agenda. Unnoticed and forgotten are obscure cases in which they intervened on behalf of tired, poor, huddled masses yearning to breathe free. How many recall Gegiow v. Uhl, ${ }^{2 s}$ in which Van Devanter and McReynolds joined the opinion overturning the decision of the Commissioner of Immigration, who had excluded and detained a group of illiterate Russian laborers on the basis of their ignorance, poverty, and the overstocked state of the labor market in the city of their destination? Or White v. Chin Fong, ${ }^{226}$ the 1920 case in which Van Devanter and McReynolds repulsed an effort by the Commissioner of Immigration to deny re-entry to a Chinese merchant whom the government alleged had earlier entered the country by means of fraud? How about Kwock Jan Fat v. White, ${ }^{227}$ decided the same year, in which Van Devanter and McReynolds joined the opinion granting a writ of habeas corpus to a plaintiff claiming unlawful detention under the Chinese exclusion laws, and denouncing the investigation into the plaintiff's claim of native U.S. citizenship as "manifestly unfair"?"22s Or Cheung Sum Shee 
v. Nagle, ${ }^{229}$ in which each of his fellow Horsemen joined McReynolds' opinion denouncing the Secretary of Labor's heartless refusal to admit the alien wives and minor children of resident Chinese merchants lawfully domiciled in the United States? Who remembers that McReynolds and Butler joined the opinion in the 1939 case of Perkins $v$. Elg, ${ }^{230}$ in which the Court stifled attempts to deport as an illegal alien a woman born in the United States to Swedish parents who had removed her to Sweden and renounced their American citizenship during her minority? Or the permissive posture struck by Van Devanter, McReynolds, and Sutherland in Hansen v. Haff, , $^{231}$ in which they frustrated an attempt to deport a Danish woman who returned to the United States with the intention of continuing to engage in illicit sexual relations with a married man, joining the Court's refusal to characterize her entry as one for an "immoral purpose"? ?22 You will perhaps say that this comes as no great surprise, in light of Van Devanter's and McReynolds' performances in United States $v$. Lombardo, ${ }^{233}$ the 1916 case in which they voted to sustain, on jurisdictional grounds, a demurrer to the indictment of a defendant charged with harboring an alien woman in her home for purposes of prostitution. ${ }^{234}$

Similarly, the votes of Butler and Van Devanter to uphold the notorious western Alien Land Laws ${ }^{235}$ have served to eclipse the Four Horsemen's quiet interventions on behalf of aliens to whom various state, local, and territorial governments sought to deny the right to pursue a lawful calling on terms of equality with all others. Some may recall that Van Devanter joined Justice Hughes' opinion in the 1915 case of Truax v. Raich, ${ }^{236}$ invalidating an Arizona statute requiring that eighty percent of an employer's employees be native born citizens or qualified electors. ${ }^{23}$ But how many could recite the facts of Asakura $v$. Seattle, ${ }^{238}$ in which each of his fellow Horsemen joined Butler's opinion invalidating a city ordinance denying a Japanese national a license to engage in the pawnbroking business? Or those of Jordan $v$. Tashiro, ${ }^{239}$ in which all Four Horsemen joined the Court's opinion invalidating California's attempt to prohibit Japanese aliens from leasing land and acquiring a corporate franchise for the purpose of operating a hospital? ${ }^{240}$ Or those of $Y u$ Cong Eng v. Trinidad, ${ }^{241}$ in which all Four Horsemen voted 
to invalidate a law of the Philippine Islands prohibiting merchants from keeping account books in any other than one of three approved languages? The Court held that the burden this law placed on a Chinese businessman who was unable to read, write or understand any of the permitted languages constituted an arbitrary and discriminatory deprivation of liberty and property without due process and a denial of equal protection. ${ }^{242}$ These efforts to establish a beachhead for an alien middle class on American soil are lost to all but the most tenacious of memories.

V.

Seen against the backdrop of their spadework for big government and the welfare state, their softness on crime and drugs, their shifty support of political dissent and their surreptitious solicitude for a multicultural America at the height of national xenophobia, the Horsemen's occasional railings against the encroachments of the modern regulatory state seem to be instances of the Justices protesting too much. Their success in projecting and perpetuating their images as right-wing reactionaries not only throughout their careers, but so long after their deaths, is testimony to their tactical brilliance. They are perhaps the greatest double agents of the interwar period. Their story is a reminder to us, as legal historians, of the need for eternal vigilance. I pray we don't get fooled again. 


\section{ENDNOTES}

${ }^{1}$ See Charles Fountain, Sportswriter: The Life and Times of Grantland Rice 27 (1993).

${ }^{2}$ See, e.g., Richard C. Cortner, The Wagner Act Cases 142-43 (1964); Peter H. Irons, The New Deal Lawyers 13 (1982); Alfred H. Kelly \& Winfred A. Harbison, The American Constitution: Its Origins and Development 736-37 (4th ed. 1970); William E. Leuchtenburg, Franklin D. Roosevelt and the New Deal 143 (1963); Alpheus T. Mason, The Supreme Court from Taft to Burger 52 (1979); Drew Pearson \& Robert S. Allen, The Nine Old Men, 186, 198, 228 (1936); Arthur M. Schlesinger, Jr., The Politics of Upheaval 455-60 (1960); Carl B. Swisher, American Constitutional Development 920 (2d ed. 1954).

${ }^{3} 261$ U.S. 525 (1923).

${ }^{4}$ Morehead v. New York ex rel. Tipaldo, 298 U.S. 587 (1936).

s295 U.S. 330 (1935).

' 277 U.S. 350 (1928).

7247 U.S. 251 (1918).

${ }^{8}$ Carter v. Carter Coal Co., 298 U.S. 238 (1936).

9 Nebbia v. New York, 291 U.S. 502, 539 (1934) (McReynolds, J., dissenting).

${ }^{10}$ Home Bldg. \& Loan Ass'n v. Blaisdell, 290 U.S. 398, 448 (1934) (Sutherland, J., dissenting).

"Perry v. United States, 294 U.S. 330, 361 (1935) (McReynolds, J., dissenting); Nortz v. United States, 294 U.S. 317, 361 (1935) (McReynolds, J., dissenting); Norman v. Baltimore \& O.R.R., 294 U.S. 240, 361 (1935) (McReynolds, J., dissenting).

${ }_{12}$ See Associated Press v. NLRB, 301 U.S. 103, 133 (1937) (Sutherland, J., dissenting); NLRB v. Friedman-Harry Marks Clothing Co., 301 U.S. 58, 76 (1937) (McReynolds, J., dissenting); NLRB v. Fruehauf Trailer Co., 301 U.S. 49, 76 (1937) (McReynolds, J., dissenting); NLRB v. Jones \& Laughlin Steel Corp., 301 U.S. 1, 76 (1937) (McReynolds, J., dissenting).

${ }^{13}$ Joel F. Paschal, Mr. Justice Sutherland: A Man Against the State 36, 56, 63 (1951).

"4 Harold M. Stephens, Mr. Justice Sutherland, 31 A.B.A. J. 446, 446 (1945).

${ }^{15}$ Paschal, supra note 13 , at $63,65-71$. It was in support of workmen's compensation that Sutherland cited with approval "a growing feeling that the individualistic theory has been pushed with too much stress upon the dry logic of its doctrines and too little regard for their practical operation from the humanitarian point of view." Id. at 71, quoting Compulsory Workmen's Compensation Law, Sen. Doc. No. 131, 63d Cong., 1st Sess. 11 (1913). "[A] good many people," he remarked sarcastically, "perversely insist upon being fed and clothed and comforted by the practical rule of thumb rather than by the exact rules of logic." Id.

${ }^{16}$ David J. Danelski, A Supreme Court Justice is Appointed 18 (1964). In a 1908 speech before the Minnesota Bar Association, Butler argued strenuously for enactment of such a program. "Should employees, injured while engaged in hazardous occupations carried on for the benefit of the public, bear the loss, if there be no negligence chargeable to the employer?" Butler asked:

Every well organized business concern makes provision out of earnings for the creation of a fund to cover impairment in value of machinery and plant by rea- 
son of wear, tear and accidental injury or destruction. Would a similar provision for the compensation of men injured while engaged in the service, without wrongdoing on their own part, be imposing more of a burden than industries can bear? Would not the added expense be included in the cost of the service or of the product, contributed to by employees be added to the selling price and paid by the public? Is not the distribution of the loss by any reasonable means in such a way that the public or consumers as a whole shall bear it, preferable to the leaving of the burden upon the unfortunate few who suffer the loss under the present system?

Francis J. Brown, The Social and Economic Philosophy of Pierce Butler 96 n.54 (1945) (quoting Proceedings, Minnesota Bar, 42 (1908)). Butler concluded:

[I]n certain occupations attended by grave and peculiar risks of injury to employees, there should be compensation for injuries, irrespective of the negligence of the master, unless such injury was the result of wrongful conduct on the part of the injured person or occurred by reason of irresistible force or an act of providence; in other words, that in such cases, the industries-or the public-should bear the loss resulting from such hazards and risks.

Id. at $96-97$.

17 See Brown, supra note 16, at 2-3; Danelski, supra note 16, at 11-13.

${ }^{18}$ David Burner, Pierce Butler, in 3 The Justices of the United States Supreme Court, 1789 - 1969: Their Lives and Major Opinions 2183, 2184 (Leon Friedman \& Fred L. Israel eds., 1969).

${ }^{19}$ See James E. Bond, I Dissent: The Legacy of Chief [sic] Justice James Clark McReynolds 4, 9, 29-42, 116-18, 126, 136 (1992); Proceedings of the Bar and Officers of the Supreme Court of the United States: In Memory of James Clark McReynolds $17-18,25-26,54,57,62-63$ (1947).

${ }^{20}$ John E. Semonche, Charting the Future: The Supreme Court Responds to a Changing Society, 1890-1920, at 249 (1978).

${ }^{21}$ Fred Rodell, Nine Men: A Political History of the Supreme Court from 17901955, at 217 (1955). See also Irving Brant, Storm Over the Constitution 240 (1936) (describing Supreme Court opinions as aligned with the interests of the industrial oligarchy).

${ }^{22}$ See, e.g., Colorado Nat'l Bank v. Bedford, 310 U.S. 41 (1940) (upholding state tax on National Bank as not infringing the tax immunity of the federal government, with McReynolds joining opinion); Chesebro v. Los Angeles County Flood Control Dist., 306 U.S. 459 (1939) (McReynolds joins Butler's opinion holding that flood district's denial of hearing to residents before taxing did not violate Due Process Clause); Guaranty Trust Co. v. Virginia, 305 U.S. 19 (1938) (upholding right of state to tax income received from a trust which had already been taxed by another state as not violating the Due Process Clause, with Butler joining McReynolds' opinion); Guaranty Trust Co. v. Commissioner, 303 U.S. 493 (1938) (favoring interpretation of commissioner allowing taxation of decedent's partnership interest, with Butler joining opinion) (McReynolds dissents); United States v. Wurts, 303 U.S. 414 (1938) (holding that the statute of limitations for the government to sue to recover tax refunds erroneously paid to taxpayer did not begin to run until the refund was actually paid, with Butler and McReynolds joining opinion); Atkinson v. State Tax Comm'n, 303 U.S. 20 (1938) (per curiam) (McReynolds and Butler join opinion upholding imposition of state income tax on individuals claiming federal immunity); Sonzinsky v. United States, 300 U.S. 506 (1937) (upholding tax component of National Firearms 
Act and noting that a tax may have a regulatory effect and burden the thing taxed, with all Four Horsemen joining opinion); New York ex rel. Cohn v. Graves, 300 U.S. 308 (1937) (holding that a state may tax income of citizens derived from rents on land situated in another state, with Sutherland and Van Devanter joining opinion) (Butler and McReynolds dissent); Taber v. Indian Terr. Illuminating Oil Co., 300 U.S. 1 (1937) (upholding a state tax on company providing oil and gas to Indian allotments as not infringing on the tax immunity of the federal government, with all Four Horsemen joining opinion); Liggett \& Myers Tobacco Co. v. United States, 299 U.S. 383 (1937) (upholding a federal tax on tobacco products purchased by a state for use in state hospitals, with Butler, Sutherland, and Van Devanter joining McReynolds' opinion); New York ex rel. Whitney v. Graves, 299 U.S. 366 (1937) (expanding state right to tax non-residents by ruling that intangible property may have a "business situs" in state for tax purposes, with all Four Horsemen joining opinion); Wainer v. United States, 299 U.S. 92 (1936) (upholding federal statutes placing tax on the wholesale liquor business, with all Four Horsemen joining opinion); Baltimore Nat'l Bank v. State Tax Comm'n, 297 U.S. 209 (1936) (upholding state tax on national bank shares belonging to the Reconstruction Finance Corporation as not infringing on the tax immunity of federal government, with all Four Horsemen joining opinion); Milwaukee County v. M.E. White Co., 296 U.S. 268 (1935) (holding that state and federal courts can entertain suits to collect tax judgments rendered by the courts of another state, and that such judgments cannot be denied full faith and credit, with Van Devanter and Sutherland joining opinion) (Butler and McReynolds dissent); Nickey v. Mississippi, 292 U.S. 393 (1934) (holding that there was no constitutional requirement that opportunity to contest tax assessment be given before assessment, with all Four Horsemen joining opinion); Roberts v. Richland Irrig. Dist., 289 U.S. 71 (1933) (upholding irrigation tax district assessment on taxpayer whose payments exceeded the value of benefits received, with Butler, Sutherland, and Van Devanter joining McReynolds' opinion); First Nat'l Bank v. Louisiana Tax Comm'n, 289 U.S. 60 (1933) (upholding state tax on certain transactions in national banks against an Equal Protection Clause challenge, with all Four Horsemen joining opinion); Burnet v. Jergins Trust, 288 U.S. 508 (1933) (upholding federal tax on private company leasing lands for oil and gas excavation from state as not violating immunity of state, with all Four Horsemen joining opinion); Guaranty Trust Co. v. Blodgett, 287 U.S. 509 (1933) (accepting a state supreme court construction of state tax, and thus refusing to consider a Contracts Clause violation, with Butler, McReynolds, and Van Devanter joining Sutherland's opinion); Continental Baking Co. v. Woodring, 286 U.S. 352 (1932) (upholding state system of taxation for use of its public highways that created various exceptions as not violating the Fourteenth Amendment, with all Four Horsemen joining opinion); Michigan v. Michigan Trust Co., 286 U.S. 334 (1932) (holding that the Court was bound by a state court decision construing a tax on the privilege of doing business in state as applied to a corporate receiver, with Butler, Sutherland, and Van Devanter joining opinion); Lawrence v. State Tax Comm'n, 286 U.S. 276 (1932) (declaring that a state has the power to tax its own citizens on their net incomes though derived wholly from activities conducted outside of state, with Butler, McReynolds, and Sutherland joining opinion) (Van Devanter dissents in part); Matthews v. Rodgers, 284 U.S. 521 (1932) (restricting the power of federal courts to enjoin the collection of an allegedly unconstitutional state tax where remedy of paying under protest and then suing existed under state law, with all Four Horsemen joining opinion); Graniteville Mfg. Co. v. Query, 283 U.S. 376 (1931) (upholding state stamp tax on promissory notes executed within its borders, with all 
Four Horsemen joining opinion); Storaasli v. Minnesota, 283 U.S. 57 (1931) (upholding a state tax and registration law for motor vehicles as it applied to nonresidents as not violative of the Equal Protection Clause, with McReynolds, Sutherland, and Van Devanter joining opinion) (Butler takes no part); Henrietta Mills v. Rutherford County, 281 U.S. 121 (1930) (disallowing a suit claiming inequality in taxation because an adequate remedy existed at state law, with all Four Horsemen joining opinion); Helson \& Randolph v. Kentucky, 279 U.S. 245 (1929) (striking down state tax on gasoline purchased out of state and used to power an interstate ferry as violating the Commerce Clause); St. Louis \& S.W. Ry. v. Nattin, 277 U.S. 157 (1928) (holding that state law authorizing creation of local taxing district did not require notice to taxpayer to conform with due process, with Butler, Sutherland, and Van Devanter joining McReynolds' opinion); Long v. Rockwood, 277 U.S. 142 (1928) (Sutherland dissents from opinion holding that a state may not tax income received from patents issued by federal government); Fidelity Nat'l Bank \& Trust Co. v. Swope, 274 U.S. 123 (1927) (holding that notice to taxpayers of special tax assessment listed in a newspaper was sufficient to avoid Due Process Clause violation, with all Four Horsemen joining opinion); Mid-Northern Oil Co. v. Montana, 268 U.S. 45 (1925) (holding that state had implied consent to tax instrumentality of federal government, with Butler, McReynolds, and Van Devanter joining Sutherland's opinion); House v. Road lmprovement Dist., 266 U.S. 175 (1924) (holding that state road improvement tax on property not benefited by such improvement did not violate Fourteenth Amendment, with Butler, Sutherland, and Van Devanter joining McReynolds' opinion); Hetrick v. Village of Lindsey, 265 U.S. 384 (1924) (holding that state need not give notice concerning special tax assessment where state courts were open to provide a means to challenge, with all Four Horsemen joining opinion); Lacoste v. Department of Conservation, 263 U.S. 45 (1924) (upholding right of state to tax wild animals taken within border against Commerce Clause challenge, with McReynolds, Sutherland, and Van Devanter joining Butler's opinion); McGregor v. Hogan, 263 U.S. 234 (1923) (upholding state tax statute which made assessment first, allowing a hearing after payment, as not violating Due Process Clause, with all Four Horsemen joining opinion); Butters v. City of Oakland, 263 U.S. 162 (1923) (holding that municipal improvement taxes assessed on those who would receive little benefit did not violate Fourteenth Amendment, with Butler, McReynolds, and Van Devanter joining Sutherland's opinion); Thomas v. Kansas City S. Ry., 261 U.S. 481 (1923) (upholding drainage taxing district, ruling that state decision will survive Fourteenth Amendment challenge unless clearly arbitrary and discriminatory, with all Four Horsemen joining opinion); Valley Farms Co. v. County of Westchester, 261 U.S. 155 (1923) (holding that state tax for sewer system, which placed tax on those who received no benefit from project, was valid against Fourteenth Amendment challenge, with Butler, Sutherland, and Van Devanter joining McReynolds' opinion); Bankers Trust Co. v. Blodgett, 260 U.S. 647 (1923) (holding that retroactive state tax penalties were not prohibited by constitutional ban on ex post facto laws, with all Four Horsemen joining opinion); United States v. Stafoff, 260 U.S. 477 (1923) (upholding a tax on the illegal production of alcohol, with all Four Horsemen joining opinion); Knights v. Jackson, 260 U.S. 12 (1922) (upholding state tax scheme which levied general state tax and then returned revenues to municipalities as not violating Fourteenth Amendment, with all Four Horsemen joining opinion); Charlotte Harbor \& N. Ry. Co. v. Welles, 260 U.S. 8 (1922) (holding that city tax, originally invalid because of lack of power of municipality to levy tax did not conflict with Due Process Clause once it was ratified by state legislature, with all Four Horsemen joining opinion); Fidelity Title \& 
Trust Co. v. United States, 259 U.S. 304 (1922) (upholding tax on banking surplus where bank could not demonstrate that its undivided profits were not used as capital, with McReynolds and Van Devanter joining opinion); Heald v. District of Columbia, 259 U.S. 114 (1922) (upholding congressional taxation of D.C. despite lack of representation for citizens of D.C., with McReynolds and Van Devanter joining opinion); Burrill v. Locomobile Co., 258 U.S. 34 (1922) (reversing judgment that awarded company repayment of erroneous taxes paid because company did not file claim within statute of limitations, with McReynolds and Van Devanter joining opinion); Breiholz v. Board of Supervisors, 257 U.S. 118 (1921) (Van Devanter joins opinion upholding drainage district assessment which paid for cleaning and maintenance of facilities as not violative of the Fourteenth Amendment) (McReynolds concurs in result); Dane v. Jackson, 256 U.S. 589 (1921) (holding that Massachusetts tax scheme which took more tax money from town than it received in benefits did not violate the Fourteenth Amendment, with McReynolds and Van Devanter joining opinion); Miller \& Lux, Inc. v. Sacramento \& San Joaquin Drainage Dist., 256 U.S. 129 (1921) (holding that state may tax residents for drainage district without taking into account actual benefits received, with McReynolds and Van Devanter joining opinion); Green v. Frazier, 253 U.S. 233 (1920) (Van Devanter and McReynolds join opinion upholding North Dakota tax imposed to subsidize private industry against claims that the expenditures were not for a legitimate public purpose); McGuire v. Trefry, 253 U.S. 12 (1920) (Van Devanter joins opinion upholding Massachusetts' taxation of trust income paid to a Massachusetts beneficiary of a Pennsylvania trust) (McReynolds dissents); Travis v. Yale \& Towne Mfg. Co., 252 U.S. 60 (1920) (Van Devanter joins opinion upholding New York's taxation of income earned in the state by nonresidents); Shaffer v. Carter, 252 U.S. 37 (1920) (Van Devanter joins opinion upholding imposition of Oklahoma tax on income derived from property and business situated within the state though owned and managed from outside the state by a nonresident) (McReynolds dissents); Hancock v. Muskogee, 250 U.S. 454 (1919) (holding that in levying a sewer district tax, city need not have a hearing to conform with Due Process where state delegates its taxing power, with McReynolds and Van Devanter joining opinion); St. Louis Poster Adv. Co. v. St. Louis, 249 U.S. 269 (1919) (upholding right of city to place a burdensome tax on owners of billboards, with McReynolds and Van Devanter joining opinion); Withnell v. Ruecking Constr. Co., 249 U.S. 63 (1919) (upholding city tax bill for paving road, despite inequalities in assessment and despite lack of public hearing on project, as not violating Fourteenth Amendment, with McReynolds and Van Devanter joining opinion); McCurdy v. United States, 246 U.S. 263 (1918) (affirming right of state to tax land owned by Native American, against challenge by Secretary of Interior, with McReynolds and Van Devanter joining opinion); Jones v. City of Portland, 245 U.S. 217 (1917) (holding that state tax levied to create a fuel yard for residents did not violate Fourteenth Amendment, with McReynolds and Van Devanter joining opinion); Seton Hall College v. Village of S. Orange, 242 U.S. 100 (1916) (upholding state tax on a university originally exempted from taxation under state law, with McReynolds and Van Devanter joining opinion); St. Louis \& Kansas City Land Co. v. Kansas City, 241 U.S. 419 (1916) (upholding municipal tax on widening road as not violating the Due Process Clause, with McReynolds and Van Devanter joining opinion); Embree v. Kansas City Rd. Dist., 240 U.S. 242 (1916) (holding that state taxation to pay for road district bonds did not violate the Fourteenth Amendment, with McReynolds joining Van Devanter's opinion); O'Neill v. Learner, 239 U.S. 244 (1915) (upholding right of state to create a drainage taxing district against a Fourteenth Amendment challenge, with 
McReynolds and Van Devanter joining opinion); Philip Wagner, Inc. v. Leser, 239 U.S. 207 (1915) (holding that state tax placed on property for benefit of having adjoining paved road did not violate the Fourteenth Amendment, with Van Devanter joining opinion) (McReynolds dissents); Bothwell v. Bingham County, 237 U.S. 642 (1915) (Van Devanter writes opinion upholding imposition of state tax on individual claiming federal immunity); Rainey v. United States, 232 U.S. 310 (1914) (indicating in answer to a question asked of the Court that a tax on foreign-made vessels in the use of foreign-built yachts did not violate due process, with Van Devanter joining opinion); United States v. Bennett, 232 U.S. 299 (1914) (indicating in answer to questions asked of the Court that Congress may place an excise tax on an American citizen using a foreign-made vessel outside of American waters, with Van Devanter joining opinion); Billings v. United States, 232 U.S. 261 (1914) (indicating in answer to question asked of Court that the excise tax in the Tariff Act of 1909 placed on foreign-built yachts was not contrary to the Due Process Clause, with Van Devanter joining opinion); Dowman v. Texas, 231 U.S. 353 (1913) (upholding state tax on separate owners of an estate where title has been severed, with Van Devanter joining opinion).

${ }^{23}$ See, e.g., Helvering v. Kehoe, 309 U.S. 277 (1940) (McReynolds writes opinion ruling that federal courts cannot overturn Board of Tax Appeals rulings when there was a substantial basis for their conclusions); Helvering v. Therrell, 303 U.S. 218 (1938) (upholding imposition of federal income tax on individuals claiming immunity, with Butler joining McReynolds' opinion); Minnesota Tea Co. v. Helvering, 302 U.S. 609 (1938) (holding that money received by a corporation by exchange in a reorganization and turned over to stockholders subject to stockholders' agreement to assume and pay off indebtedness of the corporation was taxable gain to the corporation, with Butler and McReynolds joining Sutherland's opinion); United States v. Garbutt Oil Co., 302 U.S. 528 (1938) (ruling that the addition of a new ground to a pending claim for a tax refund filed subsequent to the expiration of the statute of limitations was barred and that the Commissioner was without power to waive the bar in favor of the taxpayer, with Butler, McReynolds and Sutherland joining opinion); United States v. Andrews, 302 U.S. 517 (1938) (ruling statute of limitations barred taxpayer's claim for tax refund, with Butler, McReynolds and Sutherland joining opinion); Helvering v. Gowran, 302 U.S. 238 (1937) (upholding the taxation of the proceeds received on sale of a dividend of preferred stock, with all Four Horsemen joining opinion); Groman v. Commissioner, 302 U.S. 82 (1937) (affirming an income tax deficiency assessment of the Board of Tax Appeals in face of reversal by court of appeals, with all Four Horsemen joining opinion); Helvering v. Midland Mut. Life Ins. Co., 300 U.S. 216 (1937) (interpreting revenue acts to include as income amounts realized by insurance companies at foreclosure sales, with Butler, Sutherland, and Van Devanter joining opinion) (McReynolds dissents); Elmhurst Cemetery Co. v. Commissioner, 300 U.S. 37 (1937) (holding that reversal by court of appeals of Board of Tax Appeals decision which was supported by substantial evidence was unwarranted, with Butler, Van Devanter and Sutherland joining McReynolds' opinion); United States v. Hudson, 299 U.S. 498 (1937) (upholding federal tax on profits realized from sale of silver bullion as within the taxing power of Congress, with Butler, McReynolds, and Sutherland joining Van Devanter's opinion); Schafer v. Helvering, 299 U.S. 171 (1936) (affirming an income tax deficiency assessment against a stock broker who had used market value rather than cost value in computing income for taxation of inventories of securities purchased for his own account, with Butler, Van Devanter and Sutherland joining McReynolds' opinion); United States v. Safety Car Heating \& Lighting 
Co., 297 U.S. 88 (1936) (holding that money received in settlement of a contested claim for profits was income subject to taxation despite fact that claim arose prior to passage of Sixteenth Amendment, with all Four Horsemen joining opinion); Helvering v. Powers, 293 U.S. 214 (1934) (upholding imposition of federal income tax on salaries of trustees of Boston elevated railway, with all Four Horsemen joining opinion); Ohio v. Helvering, 292 U.S. 360 (1934) (upholding federal taxation of state-run liquor dispensary system, with Van Devanter, McReynolds and Butler joining Sutherland's opinion); Willcuts v. Bunn, 282 U.S. 216 (1931) (holding that profit from the sale of municipal bond was distinct from the bond's principal or interest, and thus taxable, with all Four Horsemen joining opinion); Old Colony Trust Co. v. Commissioner, 279 U.S. 716 (1929) (holding that an employer's payment of employee's income tax assessment represents additional taxable income to the employee, with Butler, Sutherland and Van Devanter joining opinion) (McReynolds dissents); Metcalf \& Eddy v. Mitchell, 269 U.S. 514 (1926) (upholding imposition of federal income tax on profits of a private contractor from performance of a contract with a state, with all Four Horsemen joining opinion); United States v. Anderson, 269 U.S. 422 (1926) (interpreting Revenue Act of 1918 so as to disallow a claimed deduction which would have allowed taxpayer to defer tax payments one year, with Butler, McReynolds and Van Devanter joining opinion) (Sutherland dissents); United States v. Robbins, 269 U.S. 315 (1926) (presuming that a wife, under state property law, merely held an expectancy interest in husband's property, the Court held the entire amount of property taxable to the husband, with Butler, McReynolds and Van Devanter joining opinion) (Sutherland dissents); Irwin v. Gavit, 268 U.S. 161 (1925) (holding that money received under a trust arrangement was income to beneficiary and taxable, with McReynolds and Van Devanter joining opinion) (Butler and Sutherland dissent); United States v. Flannery, 268 U.S. 98 (1925) (McReynolds and Sutherland dissent from opinion, in which Butler and Van Devanter join, interpreting Revenue Act of 1918 to mean that taxes can be imposed and losses allowed only upon an actual gain or loss being suffered); Graham v. du Pont, 262 U.S. 234 (1923) (rejecting taxpayer challenge of a federal income tax assessment, with all Four Horsemen joining opinion); Walsh v. Brewster, 255 U.S. 536 (1921).(Van Devanter and McReynolds join opinion upholding taxation of gain realized upon sale of bonds); Goodrich v. Edwards, 255 U.S. 527 (1921) (Van Devanter and McReynolds join opinion upholding taxation of profit from sale of stock held for investment); Merchant's Loan \& Trust Co. v. Smietanka, 255 U.S. 509 (1921) (Van Devanter and McReynolds join opinion upholding taxation of profit from sale of stock by trust); DeGanay v. Lederer, 250 U.S. 376 (1919) (upholding income tax on investment property owned by alien non-resident, with Van Devanter joining opinion) (McReynolds takes no part); Coleman v. United States, 250 U.S. 30 (1919) (holding that although taxes were erroneously collected, taxpayer could not receive refund because of statute of limitations, with McReynolds and Van Devanter joining opinion); Peabody v. Eisner, 247 U.S. 347 (1918) (holding that dividend received was taxable up to amount gained following the passage of the Sixteenth Amendment, with McReynolds and Van Devanter joining opinion); Lynch v. Hornby, 247 U.S. 339 (1918) (ruling that corporate dividends paid to taxpayer following enactment of Sixteenth Amendment were taxable, with McReynolds and Van Devanter joining opinion); Dodge v. Brady, 240 U.S. 122 (1916) (holding that federal courts have no jurisdiction over tax disputes unless taxpayer has first paid tax and appealed to Commissioner of IRS, with Van Devanter joining opinion) (McReynolds takes no part); Dodge v. Osborn, 240 U.S. 118 (1916) (upholding constitutionality of provi- 
sions requiring taxpayer to pay taxes before making an appeal to Commissioner of IRS, with Van Devanter joining opinion) (McReynolds takes no part).

${ }^{24}$ See, e.g., Buckstaff Bath House Co. v. McKinley, 308 U.S. 358 (1939) (McReynolds joins opinion upholding imposition of state tax on entity claiming federal immunity); Newark Fire Ins. Co. v. State Bd. of Tax Appeals, 307 U.S. 313 (1939) (upholding state tax on capital stock of insurance corporation, with Butler joining the concurrence by Justice Reed) (McReynolds dissents); Clark v. Paul Gray, Inc., 306 U.S. 583 (1939) (holding that fee on cars brought into state for sale did not violate the Commerce Clause, with Butler and McReynolds joining opinion); Bonet v. Yabucoa Sugar Co., 306 U.S. 505 (1939) (upholding right of Puerto Rico not to be sued without its permission in a tax refund case, with Butler and McReynolds joining opinion); Dixie Ohio Express Co. v. State Revenue Comm'n, 306 U.S. 72 (1939) (McReynolds joins Butler's opinion upholding state tax on trucking carriers as not violative of Commerce Clause); Felt \& Tarrant Mfg. Co. v. Gallagher, 306 U.S. 62 (1939) (Butler joins McReynolds' opinion upholding application of state use tax to foreign corporation); Inter-Island Steam Nav. Co. v. Territory of Hawaii, 305 U.S. 306 (1938) (holding Hawaiian tax on utility not in conflict with federal law, and not in violation of Commerce Clause, with Butler and McReynolds joining opinion); J.D. Adams Mfg. Co. v. Storen, 304 U.S. 307, 316 (1938) (McReynolds dissents from opinion holding Indiana income tax an impermissible burden on interstate commerce); Coverdale v. Arkansas-La. Pipe Line Co., 303 U.S. 604 (1938) (Butler joins opinion upholding Louisiana tax on generating electricity against Commerce Clause challenge) (McReynolds dissents); N.Y. Rapid Transit Corp. v. City of New York, 303 U.S. 573 (1938) (holding tax on utilities doing business in city not violative of Fourteenth Amendment, with Butler and McReynolds joining opinion); Schuylkill Trust Co. v. Pennsylvania, 302 U.S. 506 (1938) (McReynolds, Sutherland and Butler join opinion upholding state taxation of trust company); Atlantic Ref. Co. v. Virginia, 302 U.S. 22 (1937) (Butler, McReynolds and Sutherland join opinion upholding Virginia licensing fee on foreign corporations doing business in state as not violating Commerce Clause); Cincinnati Soap Co. v. United States, 301 U.S. 308 (1937) (Butler, McReynolds, and Van Devanter join Sutherland's opinion upholding tax on domestic processing of coconut oil as not violating due process); First Bank Stock Corp. v. Minnesota, 301 U.S. 234 (1937) (Van Devanter, McReynolds and Sutherland join opinion upholding state taxation of foreign corporation) (Butler takes no part); Southern Natural Gas Co. v. Alabama, 301 U.S. 148 (1937) (upholding state franchise tax on foreign corporations, with all Four Horsemen joining opinion); Henneford $v$. Silas Mason Co., 300 U.S. 577 (1937) (upholding state tax on sale of chattels brought into state in interstate commerce as not violating Commerce Clause, with Sutherland and Van Devanter joining opinion) (Butler and McReynolds dissent); State Bd. of Equalization v. Young's Marker Co., 299 U.S. 59 (1936) (upholding the power of state to exact a license fee for the privilege of importing beer from other state as not violating the Commerce and Equal Protection Clauses, with Van Devanter, McReynolds and Sutherland joining opinion) (Butler concurs in the result); Barwise v. Sheppard, 299 U.S. 33 (1936) (Butler, McReynolds and Sutherland join Van Devanter's opinion upholding state excise tax placed on the royalty interest of lessor and lessee in oil production as not violating Fourteenth Amendment); Atlantic Lumber Co. v. Commissioner of Corps. and Taxation, 298 U.S. 553 (1936) (upholding state privilege tax on corporation whose head office was in state, with Butler, McReynolds and Van Devanter joining Sutherland's opinion); Morf v. Bingaman, 298 U.S. 407 (1936) (upholding state tax on the privilege of using public highways for commercial 
purposes, with all Four Horsemen joining opinion); Wheeling Steel Corp. v. Fox, 298 U.S. 193 (1936) (holding that state may tax property of corporation incorporated in another state but having a situs in the taxing state, with all Four Horsemen joining opinion); Norfolk \& W. Ry. v. North Carolina ex rel. Maxwell, 297 U.S. 682 (1936) (holding that state tax on railroad income did not violate Commerce Clause where state used a reasonable method to arrive at in-state earnings, with all Four Horsemen joining opinion); Georgia Ry. \& Elec. Co. v. Decatur, 297 U.S. 620 (holding that state did not violate due process by assessing paving costs on street railway without regard to benefit received, with Butler, Sutherland and Van Devanter joining McReynolds' opinion); Matson Nav. Co. v. State Bd. of Equalization, 297 U.S. 441 (1936) (holding that state may lay a privilege tax on corporation involved in interstate commerce, with McReynolds, Sutherland and Van Devanter joining Butler's opinion); Pacific Tel. \& Tel. Co. v. Tax Comm'n, 297 U.S. 403 (1936) (upholding state tax levied on foreign common carrier for privilege of doing local business, measured by gross income of business, as not violating Commerce Clause, with all Four Horsemen joining opinion); Clyde Mallory Lines v. Alabama ex rel. State Docks Comm'n, 296 U.S. 261 (1935) (upholding state harbor fee exaction, with all Four Horsemen joining opinion); Aero Mayflower Transit Co. v. Georgia Pub. Serv. Comm'n, 295 U.S. 285 (1935) (upholding state license tax on private carriers operating motor vehicles for hire as not violating the Commerce Clause or the Fourteenth Amendment, with all Four Horsemen joining opinion); Wiloil Corp. v. Pennsylvania, 294 U.S. 169 (1935) (upholding state tax on gasoline sold or delivered by distributors as not violating Commerce Clause, with McReynolds, Sutherland and Van Devanter joining Butler's opinion); Detroit Int'l Bridge Co. v. Corporation Tax Appeal Bd., 294 U.S. 83 (1935) (upholding a state tax on the operators of a toll bridge spanning Canadian border, with Butler, Sutherland and Van Devanter joining McReynolds'opinion); Old Mission Portland Cement Co. v. Helvering, 293 U.S. 289 (1934) (disallowing deductions of bond discounts when the underlying transaction was between two affiliated companies, with McReynolds, Sutherland and Van Devanter joining opinion) (Butler dissents); Virginia v. Imperial Coal Sales Co., 293 U.S. 15 (1934) (upholding state property tax on corporation's property in state but employed in interstate commerce as not violating Commerce Clause, with all Four Horsemen joining opinion); Healy v. Ratta, 292 U.S. 263 (1934) (holding that challenger of a state license tax did not meet the amount in controversy requirement necessary to question the law in federal court, with all Four Horsemen joining opinion); Monamotor Oil Co. v. Johnson, 292 U.S. 86 (1934) (upholding state gasoline tax placed on importer as not violating Commerce Clause, with all Four Horsemen joining opinion); Magnano Co. v. Hamilton, 292 U.S. 40 (1934) (upholding state tax on butter substitutes as not violating Commerce Clause, with Butler, McReynolds, and Van Devanter joining Sutherland's opinion); Puget Sound Power \& Light Co. v. Seattle, 291 U.S. 619 (1934) (holding that city tax on private corporation, with which the city was a direct competitor, did not violate Fourteenth Amendment) (McReynolds, Sutherland and Butler concur in Van Devanter's specially concurring opinion); Chassaniol v. City of Greenwood, 291 U.S. 584 (1934) (upholding a state occupation tax on cotton trading business as not violating Commerce Clause even though cotton would be shipped out of state, with all Four Horsemen joining opinion); Trinityfarm Constr. Co. v. Grosjean, 291 U.S. 466 (1934) (Van Devanter, McReynolds and Sutherland join Butler's opinion upholding imposition of state excise tax on business claiming federal immunity); Pacific Tel. \& Tel. Co. v. Seattle, 291 U.S. 300 (1934) (upholding city license tax on telephone company with all Four Horsemen joining opinion); Federal Compress \& 
Warehouse Co. v. McLean, 291 U.S. 17 (1934) (holding a state tax on storing and compressing cotton did not violate Commerce Clause, with all Four Horsemen joining opinion); Minnesota v. Blasius, 290 U.S. 1 (1933) (upholding state's taxation of cattle bought in another state and held briefly before resale, with all Four Horsemen joining opinion); Edelman v. Boeing Air Transp., Inc., 289 U.S. 249 (1933) (holding state tax on airline fuel used in interstate transportation did not violate Commerce Clause, with Butler, McReynolds and Sutherland joining opinion) (Van Devanter takes no part); Nashville, C. \& St. L. Ry. v. Wallace, 288 U.S. 249 (1933) (holding state privilege tax on railway carrier's storage and withdrawal of gasoline from tanks did not violate Commerce Clause or Fourteenth Amendment, with all Four Horsemen joining opinion); Union Bank \& Trust Co. v. Phelps, 288 U.S. 181 (1933) (holding that tax which distinguished between commercial bankers and mere lenders did not violate Equal Protection Clause, with Butler, Sutherland and Van Devanter joining McReynolds' opinion); Broad River Power Co. v. Query, 288 U.S. 178 (1933) (holding state tax on producers using water and steam to produce electricity did not violate Equal Protection Clause, with all Four Horsemen joining opinion); Detroit Int'l Bridge Co. v. Corporation Tax Appeal Bd., 287 U.S. 338 (1932) (upholding state tax previously struck down by Court because re-computation brought tax within Fourteenth Amendment requirements, with McReynolds, Sutherland and Van Devanter joining Butler's opinion); Gregg Dyeing Co. v. Query, 286 U.S. 472 (1932) (holding state gasoline tax on gas stored for future use within state did not violate Commerce Clause, with all Four Horsemen joining opinion); Continental Baking Co. v. Woodring, 286 U.S. 352 (1932) (upholding state scheme for taxation and regulation of commercial motor carriers, with all Four Horsemen joining opinion); Utah Power \& Light Co. v. Pfost, 286 U.S. 165 (1932) (holding that state can tax electric generation without violating the Commerce Clause, despite the fact that interstate and intrastate generation were inseparable, with Butler, McReynolds and Van Devanter joining Sutherland's opinion); Fox Film Corp. v. Doyal, 286 U.S. 123 (1932) (holding that revenue from copyrights issued by federal government were not exempt from state taxation because of federal government tax immunity, with all Four Horsemen joining opinion); Pacific Co. v. Johnson, 285 U.S. 480 (1932) (McReynolds joins opinion upholding a state tax on revenue from bonds exempted from state taxation at time of purchase) (Butler, Sutherland and Van Devanter dissent); Eastern Air Transp., Inc. v. South Carolina Tax Comm'n, 285 U.S. 147 (1932) (holding state tax on fuel supplied to airplanes traveling in interstate commerce did not violate Commerce Clause, with all Four Horsemen joining opinion); Southern Ry. v. Kentucky, 284 U.S. 338 (1932) (upholding state tax previously struck down by Court because recomputation brought tax within Fourteenth Amendment requirements, with McReynolds, Sutherland and Van Devanter joining Butler's opinion); Phillips v. Commissioner of Internal Revenue, 283 U.S. 589 (1931) (holding that taxpayers who have received the assets of a dissolved corporation may be compelled to discharge the corporation's unpaid taxes, with all Four Horsemen joining opinion); East Ohio Gas Co. v. Tax Comm'n, 283 U.S. 465 (1931) (holding a state tax on natural gas did not violate the Commerce Clause, with McReynolds, Sutherland and Van Devanter joining Butler's opinion); Susquehanna Power Co. v. State Tax Comm'n, 283 U.S. 297 (1931) (holding that as a general rule tax exemptions of one government must be construed so as not to unduly impair the taxing power of another government, with all Four Horsemen joining opinion); Group No. 1 Oil Corp. v. Bass, 283 U.S. 279 (1931) (upholding federal tax on oil sales, with all Four Horsemen joining opinion); Interstate Transit Inc. v. Lindsey, 283 U.S. 183, 191 (1931) (McReynolds dissents from 
opinion striking down as violating the Commerce Clause a state privilege tax on automobiles exclusively engaged in interstate commerce); Alward v. Johnson, 282 U.S. 509 (1931) (holding special tax on automobiles used in stage line did not violate Fourteenth Amendment, with Butler, Sutherland and Van Devanter joining McReynolds' opinion); Educational Films Corp. v. Ward, 282 U.S. 379 (1931) (McReynolds joins opinion upholding a state tax including in income royalties received from copyrights obtained under federal law as not infringing tax immunity of federal government); Memphis \& C. Ry. v. Pace, 282 U.S. 241 (1931) (Butler, McReynolds and Sutherland join Van Devanter's opinion holding that reasonable, nonarbitrary road district tax on railroad did not violate Fourteenth Amendment); Klein v. Board of Tax Supervisors, 282 U.S. 19 (1930) (holding that state tax scheme in which shareholders were not taxed if corporation has at least $75 \%$ of property in state did not violate the Fourteenth Amendment, with all Four Horsemen joining opinion); Western Cartridge Co. v. Emmerson, 281 U.S. 511 (1930) (McReynolds, Sutherland and Van Devanter join Butler's opinion holding a state tax on corporation's mail order business did not violate Commerce Clause); Ohio Oil Co. v. Conway, 281 U.S. 146, 159 (1930) (noting that the Fourteenth Amendment grants no "iron rule of equality" of taxation in upholding state tax on petroleum, with all Four Horsemen joining opinion); Superior Oil Co. v. Mississippi ex rel. Knox, 280 U.S. 390 (1930) (holding that parties cannot convert a local business into an interstate business through pretense of contract to avoid state taxation, with McReynolds and Sutherland joining opinion) (Butler and Van Devanter dissent); Bekins Van Lines v. Riley, 280 U.S. 80 (1929) (holding that state tax on freight carriers which distinguished between those that operate on regular routes and others did not violate Equal Protection Clause, with Butler, Sutherland and Van Devanter joining McReynolds' opinion); Williams v. Riley, 280 U.S. 78 (1929) (holding that taxpayers did not have standing to challenge state gasoline tax on the basis of Fourteenth Amendment violations, with Sutherland joining McReynolds' opinion) (Van Devanter and Butler concur, arguing taxpayers did have standing, but that tax was valid); White River Lumber Co. v. Arkansas ex rel. Applegate, 279 U.S. 692 (1929) (holding state collection of back taxes on corporations previously undertaxed did not violate the Equal Protection Clause, with McReynolds and Sutherland joining opinion) (Butler and Van Devanter dissent); International Shoe Co. v. Shartel, 279 U.S. 429 (1929) (holding a local franchise tax which included property used in interstate commerce in its computation did not violate Commerce Clause, with Butler, Sutherland and Van Devanter joining opinion) (McReynolds dissents); New York v. Latrobe, 279 U.S. 421 (1929) (Sutherland and Van Devanter join opinion holding state franchise tax charging different rates for different kinds of stock did not violate Fourteenth Amendment) (Butler and McReynolds concur in the result); Leonard \& Leonard v. Earle, 279 U.S. 392 (1929) (Butler, Sutherland, and Van Devanter join McReynolds' opinion holding that state license tax on buying oysters did not violate Commerce Clause); Helson \& Randolph v. Kentucky, 279 U.S. 245, 252 (1929) (McReynolds dissents from opinion invalidating state gasoline tax); Carson Petroleum Co. v. Vial, 279 U.S. 95, 109 (1929) (McReynolds dissents from the opinion striking down state tax on gasoline passing through state as violative of Commerce Clause); Great N. Ry. v. Minnesota, 278 U.S. 503 (1929) (upholding state tax on railroad property which took into account property used in interstate commerce, with Butler, McReynolds and Van Devanter joining Sutherland's opinion); Hart Refineries v. Harmon, 278 U.S. 499 (1929) (holding that state can tax both use and sale of gasoline imported into state, that comes to rest in state, without violating the Commerce Clause, with Butler, McReynolds and Van Devanter 
joining Sutherland's opinion); National Leather Co. v. Massachusetts, 277 U.S. 413 (1928) (upholding state tax on foreign corporations, with Van Devanter, Sutherland and Butler joining opinion) (McReynolds dissents); Panhandle Oil Co. v. Mississippi ex rel. Knox, 277 U.S. 218 (1928) (McReynolds dissents from opinion holding that state tax on gasoline was unconstitutional as it applies to sales to federal government instrumentalities); Interstate Busses Corp. v. Blodgett, 276 U.S. 245 (1928) (all Four Horsemen join opinion holding state tax charged per mile on busses traveling on state highways not violative of the Commerce Clause); Gulf Fisheries Co. v. MacInerney, 276 U.S. 124 (1928) (holding state license tax on imported fish did not violate Commerce Clause, with all Four Horsemen joining opinion); Clark v. Poor, 274 U.S. 554 (1927) (holding that state requirement that common carriers obtain a permit and pay a tax to help maintain highways did not violate Commerce Clause, with all Four Horsemen joining opinion); Hope Natural Gas Co. v. Hall, 274 U.S. 284 (1927) (holding state tax on natural gas produced within state did not violate Commerce Clause, with Butler, Sutherland and Van Devanter joining McReynolds' opinion); Swiss Oil Corp. v. Shanks, 273 U.S. 407 (1927) (noting that Fourteenth Amendment does not require uniform taxation or forbid double taxation, while upholding a franchise tax on petroleum producer, which also paid general property tax, with all Four Horsemen joining opinion); Jaybird Mining Co. v. Weir, 271 U.S. 609, 615 (1926) (McReynolds dissents from opinion restraining imposition of state tax on business claiming federal immunity); Lake Superior Consol. Iron Mines v. Lord, 271 U.S. 577 (1926) (upholding state mining tax against Equal Protection, Due Process, and Contracts Clause challenges, with Butler, Sutherland and Van Devanter joining McReynolds' opinion); Roberts \& Schaefer Co. v. Emmerson, 271 U.S. 50 (1926) (holding that state franchise tax on capital stock did not violate the Equal Protection Clause, with all Four Horsemen joining opinion); General Am. Tank Car Corp. v. Day, 270 U.S. 367 (1926) (holding state tax on rolling-stock of non-resident corporation did not violate the Commerce Clause or the Equal Protection Clause, with all Four Horsemen joining opinion); Pacific Am. Fisheries v. Alaska, 269 U.S. 269 (1925) (upholding a graduated state tax on cases of fish, which encouraged preservation and discriminated against large canneries, as not violative of Fifth Amendment, with all Four Horsemen joining opinion); Ray Consol. Copper Co. v. United States, 268 U.S. 373 (1925) (giving IRS discretion to prescribe the method for ascertaining the value of a corporation's capital stock, with Butler, McReynolds and Van Devanter joining opinion) (Sutherland dissents); Baltimore \& O.R.R. v. City of Parkersburg, 268 U.S. 35 (1925) (holding that Court lacked jurisdiction to uphold a railroad's municipal tax exemption, with all Four Horsemen joining opinion); Barclay \& Co. v. Edwards, 267 U.S. 442 (1924) (holding congressional power to assess discriminatory taxes against a corporation was consistent with the Fifth Amendment so long as distinctions were reasonable, with all Four Horsemen joining opinion); Kansas City S. Ry. v. Road Improvement Dist. No. 3, 266 U.S. 379 (1924) (holding that a state act requiring the cost of road improvements to be distributed according to the benefits received did not violate Fourteenth Amendment, with Butler, McReynolds and Sutherland joining Van Devanter's opinion); National Paper \& Type Co. v. Bowers, 266 U.S. 373 (1924) (upholding taxation on domestic corporation despite contention that Congress violated Fifth Amendment by exempting foreign competitors, with all Four Horsemen joining opinion); Gorham Mfg. Co. v. State Tax Comm'n, 266 U.S. 265 (1924) (holding that a foreign taxpayer taxed in state must first exhaust state remedy before district court can have jurisdiction, with all Four Horsemen joining opinion); Bass, Ratcliff \& Gretton, Ltd. v. State Tax Comm'n, 266 U.S. 271 (1924) (reaffirming right 
of state to tax foreign corporation for business done within state as not violating Due Process or Commerce Clauses, with Butler, Sutherland and Van Devanter joining opinion) (McReynolds dissents); Chicago Gt. W. Ry. v. Kendall, 266 U.S. 94 (1924) (refusing to enjoin enforcement of tax merely because of mistake in valuation, with all Four Horsemen joining opinion); Southeastern Express Co. v. Robertson, 264 U.S. 535 (1924) (holding state tax which taxes similar industries differently, and which allows no opportunity for company to be heard regarding taxing scheme, did not violate Equal Protection Clause, with all Four Horsemen joining opinion); First Nat'l Bank of Greely v. Board of County Comm'rs, 264 U.S. 450 (1924) (holding that national bank cannot raise suit against state tax in federal court without first availing itself of state process, with Butler, McReynolds and Van Devanter joining Sutherland's opinion); J.E. Raley \& Bros. v. Richardson, 264 U.S. 157 (1924) (upholding state tax on intrastate activity of brokers and merchants who perform most of their work in interstate commerce, with Butler, McReynolds and Van Devanter joining Sutherland's opinion); Pierce Oil Corp. v. Hopkins, 264 U.S. 137 (1924) (upholding state tax on gasoline which state believed should be used in state as not violating due process, with all Four Horsemen joining opinion); Puget Sound Power \& Light Co. v. County of King, 264 U.S. 22 (1924) (upholding state tax on streetcar company against equal protection challenge, with all Four Horsemen joining opinion); Baker v. Druesedow, 263 U.S. 137 (1923) (holding that a state may tax railroads differently from other businesses without violating Due Process Clause, with all Four Horsemen joining opinion); Des Moines Nat'l Bank v. Fairweather, 263 U.S. 103 (1923) (allowing state taxation of national banks, with Butler, McReynolds and Sutherland joining Van Devanter's opinion); Schwab v. Richardson, 263 U.S. 88 (1923) (holding that state tax on corporation did not violate Commerce Clause because state attempted to tax only the business conducted in state, with all Four Horsemen joining opinion); Sonneborn Bros. v. Cureton, 262 U.S. 506 (1923) (upholding state occupation tax on goods previously shipped into state and held in storage, with Butler, Sutherland and Van Devanter joining opinion) (McReynolds concurs, arguing that Court should firmly state that interstate commerce ends when package reaches consignee); Atlantic Coast L.R.R. v. Daughton, 262 U.S. 413 (1923) (upholding power of state to tax the net income of property used in interstate commerce, with all Four Horsemen joining opinion); Pullman Co. v. Richardson, 261 U.S. 330 (1923) (Butler, McReynolds and Sutherland join Van Devanter's opinion upholding state taxation of property held by interstate businesses in state); Oliver Iron Mining Co. v. Lord, 262 U.S. 172 (1923) (holding that state may tax mining of ore because mining was not interstate commerce, with Butler, McReynolds and Sutherland joining Van Devanter's opinion); Durham Pub. Serv. Co. v. City of Durham, 261 U.S. 149 (1923) (Van Devanter, Sutherland and Butler join McReynolds' opinion upholding assessment against street railway company for paving portions of the street occupied by its tracks); Southern Ry. Co. v. Watts, 260 U.S. 519 (1923) (holding that state tax system, which assessed railroads differently from other taxpayers, did not violate Fourteenth Amendment, with all Four Horsemen joining opinion); Heisler v. Thomas Colliery Co., 260 U.S. 245 (1922) (holding that state tax which taxes different kinds of coal differently did not violate Fourteenth Amendment, with McReynolds, Sutherland and Van Devanter joining opinion); Texas Co. v. Brown, 258 U.S. 466 (1922) (upholding state oil and gasoline tax applied to local transactions, with Van Devanter and McReynolds joining opinion); Hump Hairpin Mfg. Co. v. Emmerson, 258 U.S. 290 (1922) (upholding state statute taxing capital stock of business even though it took into account a minor portion of company's interstate business revenue, with McRey- 
nolds concurring) (Van Devanter dissents); Keokuk \& Hamilton Bridge Co. v. Salm, 258 U.S. 122 (1922) (Van Devanter and McReynolds join opinion upholding dismissal of bill seeking to enjoin enforcement of state tax on toll bridge because company did not avail itself of state protesting procedures); Rafferty v. Smith, Bell \& Co., 257 U.S. 226 (1921) (holding that Congress had power to consent to Philippine export tax, with Van Devanter joining McReynolds' opinion); Citizens Nat'l Bank of Cincinnati v. Durr, 257 U.S. 99 (1921) (holding state property tax on membership in New York Stock Exchange did not violate the Equal Protection or Commerce Clauses) (McReynolds and Van Devanter concur, but express doubt whether membership apparently localized in New York was a taxable property right in Ohio); Bowman v. Continental Oil Co., 256 U.S. 642 (1921) (holding local tax on the sale and distribution of gasoline did not violate the Due Process or Equal Protection Clauses, with McReynolds and Van Devanter joining opinion); Choctaw \& G.R.R. v. Mackey, 256 U.S. 531 (1921) (holding that railroad property was liable to state assessment for road improvements, despite claim that railroad was a federal instrumentality because it had congressional consent to develop coal fields, with McReynolds and Van Devanter joining opinion); United States v. American Chicle Co., 256 U.S. 446 (1921) (upholding state stamp tax on commodities manufactured, sold or removed for sale, with McReynolds and Van Devanter joining opinion); St. Louis \& E. St. L. Elec. Ry. v. Missouri, 256 U.S. 314 (1921) (holding Missouri tax on street railway operating between two states did not violate the Commerce Clause, with McReynolds and Van Devanter joining opinion); St. Louis-S.F. Ry. v. Middlekamp, 256 U.S. 226 (1921) (holding Missouri franchise tax on domestic corporations did not violate the Fourteenth Amendment or the Commerce Clause, with McReynolds and Van Devanter joining opinion); Eldorado Coal \& Mining Co. v. Mager, 255 U.S. 522 (1921) (Van Devanter and McReynolds join opinion sustaining taxation of profit realized by sale of company's mine and plant); Postal Tel.-Cable Co. v. City of Fremont, 255 U.S. 124 (1921) (Van Devanter and McReynolds join opinion upholding city license tax on telegraph company against Commerce Clause challenge); Alaska Fish Salting \& ByProducts Co. v. Smith, 255 U.S. 44 (1921) (Van Devanter and McReynolds join opinion upholding license tax on manufacture of fish products not used for consumption); Underwood Typewriter Co. v. Chamberlain, 254 U.S. 113 (1920) (Van Devanter and McReynolds join opinion upholding imposition of Connecticut state tax on portion of Delaware corporation's income earned in Connecticut against Commerce Clause and Fourteenth Amendment challenges); Troy U.R.R. v. Mealy, 254 U.S. 47 (1920) (Van Devanter and McReynolds join opinion upholding revocation of a business tax exemption against Contracts Clause challenge); Cream of Wheat Co. v. County of Grand Forks, 253 U.S. 325 (1920) (Van Devanter and McReynolds join opinion upholding application of South Dakota tax to the stock of a South Dakota corporation doing no business within the state and having a permanent situs elsewhere, holding that the Fourteenth Amendment does not prohibit double taxation); Forged Steel Wheel Co. v. Lewellyn, 251 U.S. 511 (1920) (upholding Munitions Tax Act against companies that provide components for finished products, with McReynolds joining opinion) (Van Devanter dissents); Worth Bros. Co. v. Lederer, 251 U.S. 507 (1920) (upholding Munitions Tax Act against challenge by companies that provide components from finished products, with McReynolds joining opinion) (Van Devanter dissents); Carbon Steel Co. v. Lewellyn, 251 U.S. 501 (1920) (upholding Munitions Tax Act against challenge by companies who provide components of finished products, with McReynolds joining opinion) (Van Devanter dissents); Maryland Cas. Co. v. United States, 251 U.S. 342 (1920) (upholding tax on premiums col- 
lected by corporation, with McReynolds and Van Devanter joining opinion); Branson v. Bush, 251 U.S. 182 (1919) (holding tax on property of railroad for use in repairing highways did not violate Fourteenth Amendment, with Van Devanter joining opinion); Oklahoma Ry. v. Severns Paving Co., 251 U.S. 104 (1919) (Van Devanter joins McReynolds' opinion affirming city tax on street rail company for pavement of street surrounding right of way); Wagner v. City of Covington, 251 U.S. 95 (1919) (upholding municipal license tax on company that sells goods to businesses of other state because acting as an itinerant vendor, with McReynolds and Van Devanter joining opinion); American Mfg. Co. v. City of St. Louis, 250 U.S. 459 (1919) (upholding St. Louis license tax giving company a right to manufacture within city against Commerce Clause challenge, with McReynolds and Van Devanter joining opinion); Mackay Tel. \& Cable Co. v. City of Little Rock, 250 U.S. 94 (1919) (holding that a city tax on poles and wires maintained by company did not violate Commerce or Equal Protection Clauses, with McReynolds and Van Devanter joining opinion); Postal Tel.-Cable Co. v. City of Richmond, 249 U.S. 252 (1919) (holding that local tax on telegraph company which exceeds net returns from local business did not violate Commerce Clause, with McReynolds and Van Devanter joining opinion); G.S. Nichoas \& Co. v. United States, 249 U.S. 34 (1919) (giving liberal interpretation to tariff law placing extra duty of foreign products whose tariff costs were subsidized by the exporter's government, with McReynolds and Van Devanter joining opinion); Wells, Fargo \& Co. v. Nevada, 248 U.S. 165 (1918) (holding state tax on the property of a foreign express company held within state did not violate Commerce Clause, with McReynolds joining Van Devanter's opinion); Sunday Lake Iron Co. v. Township of Wakefield, 247 U.S. 350 (1918) (holding that individual claiming discrimination under Fourteenth Amendment in tax case must prove bad faith, with Van Devanter joining McReynolds' opinion); United States Glue Co. v. Town of Oak Creek, 247 U.S. 321 (1918) (holding state computation of income derived from interstate commerce in computing domestic corporation tax not violative of Commerce Clause, with McReynolds and Van Devanter joining opinion); United States v. Cleveland, C., Chi. \& St. L. Ry., 247 U.S. 195 (1918) (holding that company investment, entered into before tax enactment, could be taxed according to accrual since enactment, with McReynolds and Van Devanter joining opinion); Hays v. Gauley Mtn. Coal Co., 247 U.S. 189 (1918) (holding that company investment, entered into before tax enactment, could be taxed according to accrual since enactment, with McReynolds and Van Devanter joining opinion); Peck \& Co. v. Lowe, 247 U.S. 165 (1918) (McReynolds joins Van Devanter's opinion holding state tax on export company did not violate Commerce Clause); Northwestern Mut. Life Ins. Co. v. Wisconsin, 247 U.S. 132 (1918) (holding state tax on insurance company for doing business in state not a burden on interstate commerce, with McReynolds and Van Devanter joining opinion); United States v. Biwabik Mining Co., 247 U.S. 116 (1918) (holding that mining company cannot deduct moneys used to acquire mining rights, with McReynolds and Van Devanter joining opinion); General Ry. Signal Co. v. Virginia, 246 U.S. 500 (1918) (Van Devanter joins McReynolds' opinion upholding state tax on foreign corporation which installed railroad signals in state); Dalton Adding Mach. Co. v. Virginia, 246 U.S. 498 (1918) (Van Devanter joins McReynolds' opinion, holding that a foreign corporation was involved in intrastate activity and therefore subject to state licensing power); Cudahy Packing Co. v. Minnesota, 246 U.S. 450 (1918) (McReynolds joins Van Devanter's opinion upholding state tax placed on freight transportation conducted within state did not violate Commerce Clause); Spring Valley Water Co. v. San Francisco, 246 U.S. 391 (1918) (holding that money 
taken by utility in excess of board order while awaiting outcome of litigation was taxable under state law, with McReynolds and Van Devanter joining opinion); Cheney Bros. Co. v. Massachusetts, 246 U.S. 147 (1918) (McReynolds joins Van Devanter's opinion upholding Massachusetts tax on out-of-state businesses deemed to have operating branches in state); Armour \& Co. v. Virginia, 246 U.S. 1 (1918) (upholding right of Virginia to tax out-of-state merchandise sold in state, while granting license tax exemption to merchandise manufactured in Virginia and sold at point of manufacture, as not violative of Fourteenth Amendment, with McReynolds and Van Devanter joining opinion); Fidelity \& Columbia Trust Co. v. City of Louisville, 245 U.S. 54 (1917) (upholding tax on bank accounts of Kentucky resident, which were previously taxed in Missouri, with McReynolds and Van Devanter joining opinion); McCoach v. Insurance Co. of N. Amer., 244 U.S. 585 (1917) (holding that insurance company reserve fund, not necessitated by state law, cannot be deducted from income, with Van Devanter joining opinion) (McReynolds takes no part); Five Per Cent. Discount Cases, 243 U.S. 97 (1917) (overruling decision of Court of Customs Appeals allowing tariff discounts because of trade agreements with other countries, with McReynolds and Van Devanter joining opinion); Von Baumbach v. Sargent Land Co., 242 U.S. 503 (1917) (holding that value of ore taken from mine not deductible as depreciation of land, with Van Devanter joining opinion) (McReynolds takes no part); Kansas City, M. \& B.R.R. v. Stiles, 242 U.S. 111 (1916) (holding that state tax on stock of company consolidated under state law, but held in another state, did not violate Commerce Clause, with McReynolds and Van Devanter joining opinion); Pitney v. Washington, 240 U.S. 387 (1916) (affirming conviction of coupon book merchant for failing to pay license tax, with McReynolds and Van Devanter joining opinion); Rast v. Van Deman \& Lewis Co., 240 U.S. 342 (1916) (upholding state business license tax on companies advertising through coupons despite claim that it would be an undue burden on commerce, with McReynolds and Van Devanter joining opinion); Lusk v. Botkin, 240 U.S. 236 (1916) (holding that tax on Missouri corporation doing business in Kansas did not violate Commerce or Due Process Clauses, with McReynolds and Van Devanter joining opinion); Kansas City, F.S. \& M. Ry. v. Botkin, 240 U.S. 227 (1916) (holding that state tax on corporation created under state law did not violate Commerce Clause, with McReynolds and Van Devanter joining opinion); Rogers v. Hennepin County, 240 U.S. 184 (1916) (holding that state treatment of board of trade memberships as property of members did not violate the Equal Protection or Due Process Clauses, with Van Devanter joining opinion); Tyee Realty Co. v. Anderson, 240 U.S. 115 (1916) (upholding the Tariff Act of 1913 as not violating the Sixteenth Amendment or the general taxing power of Congress, with Van Devanter joining opinion) (McReynolds takes no part); Stanton v. Baltic Mining Co., 240 U.S. 103 (1916) (holding that Income Tax Law of 1913 applied to mining corporations, with Van Devanter joining opinion) (McReynolds takes no part); Brushaber v. Union Pac. R.R., 240 U.S. 1 (1916) (upholding Tariff Act of 1913, while limiting taxation uniformity requirement of the Constitution to geographical uniformity only, with Van Devanter and McReynolds joining opinion); Morris Canal \& Banking Co. v. Baird, 239 U.S. 126 (1915) (Van Devanter joins McReynolds opinion holding that tax exemption for canal company did not pass with transfer of property); Equitable Life Ass'r. Soc'y v. Pennsylvania, 238 U.S. 143 (1915) (holding Pennsylvania tax on foreign corporation's intrastate insurance receipts did not violate the Fourteenth Amendment, with McReynolds and Van Devanter joining opinion); United States v. Sherman \& Sons Co., 237 U.S. 146 (1915) (holding that importer must pay duty on goods upon importation in order to have a right to protest against 
duty, with Van Devanter joining opinion) (McReynolds takes no part); Wright v. Louisville \& Nash. R.R., 236 U.S. 687, 691 (1915) (McReynolds dissents from opinion holding that lessee was exempt from paying tax because of tax exemption of lessor); Wright v. Central of Ga. Ry., 236 U.S. 674, 687 (1915) (McReynolds dissents from opinion holding that because of tax exemption of lessor, lessee was exempt from paying state tax on property); St. Louis S.W. Ry. v. Arkansas, 235 U.S. 350 (1914) (upholding state franchise tax, with Van Devanter joining opinion) (McReynolds takes no part); Pullman Co. v. Knott, 235 U.S. 23 (1914) (holding state statute imposing tax on sleeping car companies did not violate Fourteenth Amendment, with Van Devanter and McReynolds joining opinion); Singer Sewing Mach. Co. v. Brickell, 233 U.S. 304 (1914) (holding that foreign corporation selling sewing machines in each county of state was subject to state license tax, with Van Devanter joining opinion); Browning v. City of Waycross, 233 U.S. 16 (1914) (ruling that parties may not convert a local business into an interstate business to avoid state tax through a non-essential contract, with Van Devanter joining opinion); Ohio River \& W. Ry. Co. v. Dittey, 232 U.S. 576 (1914) (upholding Ohio excise tax on intrastate earnings of railroad companies, with Van Devanter joining opinion); Stratton's Independence, Ltd. v. Howbert, 231 U.S. 399 (1913) (extending Corporation Tax Law of 1909 to mining corporations, with Van Devanter joining opinion); United States Fidelity \& Guar. Co. v. Kentucky, 231 U.S. 394 (1913) (holding license tax on businesses having representatives in state engaged in creating credit reports did not violate Commerce Clause, with Van Devanter joining opinion); Citizens' Tel. Co. v. Fuller, 229 U.S. 322 (1913) (holding state tax on telephone corporations, exempting small companies, did not violate Fourteenth Amendment, with Van Devanter joining opinion); Metropolis Theatre Co. v. Chicago, 228 U.S. 61 (1913) (holding municipal license fee based on cost of theater admission did not violate Equal Protection Clause where revenue was not taken into account, with Van Devanter joining opinion); Bacon v. Illinois, 227 U.S. 504 (1913) (holding that state tax on goods brought by state citizen from out of state did not violate Commerce Clause, with Van Devanter joining opinion); Bradley v. City of Richmond, 227 U.S. 477 (1913) (upholding state law authorizing municipal license tax on business, with Van Devanter joining opinion); Ewing v. City of Leavenworth, 226 U.S. 464 (1913) (holding that a city license tax on package delivery within a state, which required travel in another state to reach destination, did not violate Commerce Clause, with Van Devanter joining opinion); Darnell v. Indiana, 226 U.S. 390 (1912) (holding that Indiana tax placed on shares of a foreign corporation did not violate the Commerce Clause, with Van Devanter joining opinion); Banker Bros. Co. v. Pennsylvania, 222 U.S. 210 (1911) (holding imposition of state sales tax did not violate Commerce Clause, with Van Devanter joining opinion); Southern Pac. Co. v. Kentucky, 222 U.S. 63 (1911) (holding that a steamship owned by a Kentucky corporation, which did not travel to Kentucky, had a tax situs in Kentucky, with Van Devanter joining opinion); Flint v. Stone Tracy Co., 220 U.S. 107 (1911) (upholding imposition of the federal corporation tax, with Van Devanter joining opinion).

${ }^{25}$ See, e.g., Hill v. Martin, 296 U.S. 393 (1935) (all Four Horsemen join opinion holding federal courts lack jurisdiction to enjoin collection of state inheritance tax); City Bank Farmers Trust Co. v. Schnader, 293 U.S. 112 (1934) (Van Devanter, McReynolds and Sutherland join Butler opinion upholding imposition of state inheritance tax on tangible personalty situated within the state but owned by a decedent domiciled elsewhere); Burnet v. Brooks, 288 U.S. 378 (1933) (Van Devanter, McReynolds and Sutherland join opinion upholding imposition of federal estate tax 
on property situated in the United States and owned by a nonresident alien decedent) (Butler dissents); Burnet v. Guggenheim, 288 U.S. 280 (1933) (Van Devanter and McReynolds join opinion upholding imposition of federal gift tax to assets of a revocable trust upon settlor's release of the power to revoke) (Butler and Sutherland dissent); Bromley v. McCaughn, 280 U.S. 124 (1929) (McReynolds joins opinion upholding various provisions of the federal gift tax against claims that they impose direct taxes requiring apportionment, lack requisite uniformity, and violate the Fifth Amendment's Due Process Clause) (Van Devanter and Butler concur in Sutherland's dissent); Salomon v. State Tax Comm'n, 278 U.S. 484 (1929) (all Four Horsemen join opinion upholding state scheme for taxing inheritance against due process and equal protection challenges); Chase Nat'l Bank v. United States, 278 U.S. 327 (1929) (Van Devanter joins opinion rejecting Fifth Amendment and direct tax challenges to imposition of federal estate tax on proceeds of a life insurance policy) (McReynolds concurs in the result) (Sutherland and Butler dissent); Blodgett v. Silberman, 277 U.S. 1 (1928) (all Four Horsemen join opinion upholding imposition of state succession tax on intangible personalty located outside the state of the decedent's domicile); Saltonstall v. Saltonstall, 276 U.S. 260 (1928) (all Four Horsemen join opinion upholding state succession tax against due process challenge); Frick v. Pennsylvania, 268 U.S. 473 (1925) (McReynolds, Sutherland and Butler join Van Devanter's opinion upholding provision of Pennsylvania inheritance tax denying deduction for federal estate taxes paid); Stebbins v. Riley, 268 U.S. 137 (1925) (all Four Horsemen join opinion upholding a state inheritance tax system resulting in a much larger proportionate tax on larger estates against contentions that it worked a taking of property without due process and denied equal protection); Greiner v. Lewellyn, 258 U.S. 384 (1922) (holding that Congress has power to include municipal bonds in the determination of value of estate for payment of inheritance taxes, with McReynolds and Van Devanter joining opinion); Kahn v. United States, 257 U.S. 244 (1921) (upholding assessment of inheritance tax against assignee because refund statute had not passed at time of transfer, with McReynolds and Van Devanter joining opinion); New York Trust Co. v. Eisner, 256 U.S. 345 (1921) (Van Devanter and McReynolds join opinion upholding federal estate tax against Tenth Amendment and apportionment challenges); Watson v. State Comptroller, 254 U.S. 122 (1920) (Van Devanter and McReynolds join opinion upholding special state inheritance tax on certain securities against equal protection challenge); Petersen v. Iowa, 245 U.S. 170 (1917) (Van Devanter and McReynolds join opinion upholding imposition of state inheritance tax, which taxed legacies to nonresident aliens at a higher rate than those to state residents, against the claim that such imposition with respect to legacies to citizens of Denmark violated a treaty between the United States and that nation); Duus v. Brown, 245 U.S. 176 (1917) (Van Devanter and McReynolds join opinion involving legacies to citizens of Sweden, and to the same effect); Bullen v. Wisconsin, 240 U.S. 625 (1916) (Van Devanter and McReynolds join opinion upholding power of Wisconsin to impose inheritance tax on the corpus of trust revocable by a Wisconsin decedent yet situated in Illinois, notwithstanding Illinois' imposition of an inheritance tax on the same property and Wisconsin's failure to credit the amount of the Illinois tax against the amount owed to Wisconsin); Keeney v. Comptroller of New York, 222 U.S. 525 (1912) (Van Devanter joins opinion upholding imposition of graduated tax on transfer of property by deed of trust to take effect at death against due process and equal protection challenges).

${ }^{26} 273$ U.S. 12 (1927).

${ }^{27}$ Id. at 16. 
${ }^{28}$ Id. at 17 (citations omitted).

${ }^{29}$ Bruce Allan Murphy, The Brandeis/Frankfurter Connection: The Secret Political Activities of Two Supreme Court Justices 166 (1982) (citations omitted).

${ }^{30} 5$ Letters of Louis D. Brandeis 520, 523, 526-27 (Melvin I. Urofsky \& David W. Levy eds., 1978); Murphy, supra note 29, at 166-78; Lewis J. Paper, Brandeis 354-57 (1983); Philippa Strum, Louis D. Brandeis: Justice for the People 386-87 (1984); Melvin I. Urofsky, A Mind of One Piece: Brandeis and American Reform 131 (1971); David J. Danelski, The Propriety of Brandeis' Extrajudicial Conduct, in Brandeis and America 11, 26-27 (Nelson L. Dawson ed., 1989); Nelson L. Dawson, Brandeis and the New Deal, in Brandeis and America, supra, at 38, 48 (Nelson L. Dawson, ed., 1989); Thomas H. Eliot, The Advent of Social Security, in The Making of the New Deal 150, 159, 160-61 (Katie Louchheim ed., 1983); Paul Freund, Mr. Justice Brandeis, in Mr. Justice 177, 190 (Allison Dunham \& Philip B. Kurland eds., 1964); Letters from Elizabeth B. Raushenbush to Justice Louis D. Brandeis (Sept. 20, 1933; Sept. 24, 1933; Feb. 5, 1934; Feb. 12, 1934; Feb. 15, 1934) (on file with the Virginia Law Review Association).

"See 79 Cong. Rec. 9287 (1935) (remarks of Senator Wagner); Steward Mach. Co. v. Davis, 301 U.S. 548, 557, 559 (oral argument of Charles Wyzanski); Id. at 562, 564 (oral argument of Assistant Attorney General Robert Jackson).

32301 U.S. 548, 591-92 (1937).

${ }^{33}$ Helvering v. Davis, 301 U.S. 619 (1937).

301 U.S. at 613-14 (Sutherland, J., dissenting).

3s Id. at 609 (Sutherland, J., dissenting).

${ }^{36}$ Id. at 609-10 (Sutherland, J., dissenting).

${ }^{37}$ Id. at 610 (Sutherland, J., dissenting).

${ }^{38}$ See id. at 598 (McReynolds, J., dissenting); id. at 616 (Butler, J., dissenting); Helvering v. Davis, 301 U.S. at 646 (McReynolds and Butler, JJ., dissenting).

${ }^{39} 262$ U.S. 447 (1923).

${ }^{+0}$ Id. at 485-86. Sutherland disposed of the claim of unequal taxation in similar fashion. "But what burden is imposed upon the States, unequally or otherwise? Certainly there is none, unless it be the burden of taxation, and that falls upon their inhabitants, who are within the taxing power of Congress as well as that of the States where they reside." Id. at 482.

${ }^{11}$ Id. at 483.

42 Id. at 480 .

${ }^{43}$ Id. at 483.

4 ld. at 482 . It was apparently this feature of the old-age provisions of the Social Security Act that secured the votes of Van Devanter and Sutherland in Helvering v. Davis. See Steward Mach., 301 U.S. at 609, 612 (Sutherland and Van Devanter, JJ., dissenting).

45 Frothingham, 262 U.S. at 486-89.

${ }^{46}$ ld. at 487.

${ }^{47}$ Benjamin F. Wright, The Growth of American Constitutional Law 184 (1967).

* Swisher, supra note 2, at 838 . See also Paschal, supra note 13, at 212 (arguing that Sutherland's "great opinion" was his effective liberation of Congress' spending power announced in Mellon).

49 Wright, supra note 47, at 184 . 
${ }^{50}$ Edward S. Corwin, Twilight of the Supreme Court 176 (1934). See also Samuel J. Konefsky, Chief Justice Stone and the Supreme Court 102 n.11 (1945) (distinguishing Butler from Mellon:

[W] hile the interest of the federal taxpayer in the general funds of the treasury is too indefinite for him to be able to question the constitutionality of a particular expenditure, the interest of those subject to an 'earmarked' tax was sufficiently definite to give them standing to question the expenditure for a purpose said to be forbidden by the Constitution.");

Swisher, supra note 2, at 838-39 ("Congress, therefore, continued to make appropriations of this kind, largely immune from judicial scrutiny.").

${ }^{51}$ Corwin, supra note 50, at 183.

52 Wright, supra note 47 , at 184 . For cases in which the Court rejected challenges to New Deal initiatives on standing grounds, see, e.g., Kay v. United States, 303 U.S. 1, 6 (1937) (McReynolds and Butler join opinion denying defendant standing to challenge the constitutional authority of Congress to create the Home Owners' Loan Corporation); Alabama Power Co. v. Ickes, 302 U.S. 464 (1938) (McReynolds and Butler join Sutherland's opinion relying on Massachusetts v. Mellon in denying a power company standing to challenge grants and loans made by the Emergency Relief Administration of Public Works to assist in the construction of electrical distribution systems); Duke Power Co. v. Greenwood County, 302 U.S. 485 (1938) (same); California Water Serv. Co. v. Redding, 304 U.S. 252 (1938) (per curiam) (relying on Alabama Power Co.). For instances in which the Court upheld the constitutionality of New Deal spending programs (in addition to Social Security) see, e.g., Pittman v. Home Owners' Loan Corp., 308 U.S. 21, 28 (1939) (McReynolds joins opinion assuming constitutionality of Home Owners' Loan Corporation); Graves v. New York ex rel. O'Keefe, 306 U.S. 466, 492 (1939) (Butler and McReynolds, JJ., dissenting) (McReynolds and Butler apparently assuming constitutionality of Home Owners' Loan Corporation). For examples of the Court allowing lower court decisions sustaining the constitutionality of such programs to stand, see, e.g., United States ex rel. Hander v. Hill, 90 F.2d 573 (3d Cir.), cert. denied, 302 U.S. 736, reh'g. denied, 302 U.S. 779 (1937) (upholding constitutionality of Home Owners' Loan Corporation); City of Allegan v. Consumers' Power Co., 71 F.2d 477, 480 (6th Cir., 1934), cert. denied, 293 U.S. 586 (1934) (relying on Massachusetts v. Mellon in holding that power company has no right as either a federal or a state taxpayer to question the constitutionality of the Public Works Administration). For cases in which lower courts rejected challenges to New Deal spending on standing grounds, see, e.g., Arkansas-Mo. Power Co. v. City of Kennett, 78 F.2d 911, 914 (8th Cir., 1935) (relying on Mellon in upholding constitutionality of loans and grants by Public Works Administration); Iowa S. Util. Co. v. Town of Lamoni, 11 F. Supp. 581, 585 (S.D. Iowa, 1935) (relying on Mellon to deny company standing to question the constitutionality of loans and grants made by the Public Works Administration); Graff v. Town of Seward, 9 Alaska 205, 220-21 (1937) (denying plaintiff standing to challenge Public Works Administration). Perhaps because of the Mellon doctrine, a vast array of New Deal spending programs, all financed from general revenue, never underwent constitutional challenge before the Court during the Four Horsemen's tenures. See, e.g., the Civilian Conservation Corps, 48 Stat. 22, 23 (1933), the Federal Emergency Relief Act, 48 Stat. 55, 56 (1933), the Farm Credit Act, 48 Stat. 257, 258 (1933), the Reconstruction Finance Corporation, 49 Stat. 1, 4 (1935), the Rural Electrification Administration Act, 49 Stat. 1363, 1364 (1936), and the Emergency Relief Appropriation Act, 49 Stat. 1597, 1608 (1936). 
ss See Paschal, supra note 13, at 149-52.
s See Thomas L. Haskell, Capitalism and the Origins of the Humanitarian Sensi-
bility, Part I, 90 Am. Hist. Rev. 339 (1985).
ss I might be making this up, but I'm sure it's true on some deep, metaphorical level.
s6 See, e.g., Mayo v. Lakeland Highlands Canning Co., 309 U.S. 310 (1940)
(removing an injunction against state law placing regulations on citrus growers, with
McReynolds joining opinion); Ziffrin, Inc. v. Reeves, 308 U.S. 132 (1939) (McReynolds writes opinion upholding state statute requiring liquor to be transported only by licensed common carriers) (Butler takes no part); Welch Co. v. New Hampshire, 306 U.S. 79 (1939) (upholding state regulation of truck drivers, with McReynolds joining Butler's opinion); South Carolina State Hwy. Dept. v. Barnwell Bros., 303 U.S. 177 (1938) (upholding state's highway safety statute preventing certain truck transportation from entering state, with Butler and McReynolds joining opinion); National Fertilizer Ass'n v. Bradley, 301 U.S. 178 (1937) (Van Devanter, Sutherland and Butler join McReynolds' opinion upholding state labeling law); Phelps v. Board of Educ., 300 U.S. 319, 323-24 (1937) (rejecting the argument that a plan to reduce teachers' pay violated Fourteenth Amendment, with all Four Horsemen joining opinion); Henderson Co. v. Thompson, 300 U.S. 258 (1937) (upholding state regulation of natural gas, with all Four Horsemen joining opinion); Hauge v. Chicago, 299 U.S. 387 (1937) (upholding city ordinance requiring commodities sold in city to be weighed within city, with Butler, Sutherland, and Van Devanter joining McReynolds' opinion); Old Dearborn Distrib. Co. v. Seagram-Distillers Corp., 299 U.S. 183 (1936) (upholding state price regulation of commodities sold under trademarks, with Butler, McReynolds and Van Devanter joining Sutherland's opinion); Morf v. Bingaman, 298 U.S. 407 (1936) (upholding state law placing fee on cars transported in caravans for sale within state, with all Four Horsemen joining opinion); Premier-Pabst Sales Co. v. Grosscup, 298 U.S. 226 (1936) (recognizing that a state may grant licenses to sell beer only to state residents, with all Four Horsemen joining opinion); Hartford Accident \& Indem. Co. v. Illinois ex. rel. McLaughlin, 298 U.S. 155 (1936) (upholding state regulation of farm produce commission merchants, with all Four Horsemen joining opinion); Whitfield v. Ohio, 297 U.S. 431 (1936) (upholding state law preventing the sale of convict-made goods, with Butler joining Sutherland's opinion) (McReynolds and Van Devanter concur in the result); Bayside Fish Flour Co. v. Gentry, 297 U.S. 422 (1936) (upholding state regulation of sardine processing, with Butler, McReynolds, and Van Devanter joining Sutherland's opinion); Public Serv. Comm'n v. Havemeyer, 296 U.S. 506 (1936) (upholding Puerto Rican decision to revoke irrigation franchise to a private business, with McReynolds, Sutherland, and Van Devanter joining Butler's opinion); Clyde Mallory Lines v. Alabama ex rel. State Docks Comm'n, 296 U.S. 261 (1935) (upholding state harbor regulations to insure safety of vessels, with all Four Horsemen joining opinion); $\mathrm{Pa}$ cific States Box \& Basket Co. v. White, 296 U.S. 176, 181-82 (1935) (upholding state regulation of containers used to store horticulture products, with all Four Horsemen joining opinion); Gordon v. Washington, 295 U.S. 30, 32, 39 (1935) (upholding state banking law allowing state to take over "unsafe or unsound" banks, with all Four Horsemen joining opinion); Semler v. Oregon State Bd. of Dental Exam'rs., 294 U.S. 608 (1935) (upholding state regulation of dental advertising, with all Four Horsemen joining opinion); Mutual Life Ins. Co. v. Johnson, 293 U.S. 335 (1934) (interpreting state law to require payment to disabled individual, with all Four Horsemen joining opinion); Utley v. St. Petersburg, 292 U.S. 106, 109-10 (1934) (limiting the right of owner to challenge a street improvement project, with all Four Horsemen joining 
opinion); Life \& Cas. Ins. Co. v. McCray, 291 U.S. 566 (1934) (upholding state mandated extra damage awards against insurance company that delayed life insurance payment in good faith, with McReynolds joining opinion) (Butler, Sutherland, and Van Devanter dissent in part); Hartford Accident \& Indem. Co. v. N.D. Nelson Mfg. Co., 291 U.S. 352 (1934) (upholding state statute requiring insurance on laborers, with all Four Horsemen joining opinion); Alabama v. Arizona, 291 U.S. 286 (1934) (denying suit on justiciability grounds by one state against another because state refused to allow into market products made by prisoners, with McReynolds, Sutherland, and Van Devanter joining Butler's opinion); Gibbes v. Zimmerman, 290 U.S. 326 (1933) (upholding state law giving governor plenary power over all state banks, with all Four Horsemen joining opinion); Hicklin v. Coney, 290 U.S. 169 (1933) (upholding fees placed on private contract carriers for use of state highways, with all Four Horsemen joining opinion); Mintz v. Baldwin, 289 U.S. 346, 350 (1933) (upholding power of state to require certification of imported cattle to prevent the spread of infectious disease, with McReynolds, Sutherland, and Van Devanter joining Butler's opinion); Gant v. Oklahoma City, 289 U.S. 98 (1933) (upholding city ordinance requiring payment of bond in order to drill for gas or oil in city, with Butler, McReynolds, and Van Devanter joining Sutherland's opinion); C.A. Bradley v. Public Util. Comm'n, 289 U.S. 92 (1933) (upholding right of state to deny access of roads to motor carrier, with all Four Horsemen joining opinion); Dickson v. Uhlmann Grain Co., 288 U.S. 188 (1933) (upholding state law outlawing certain commodity trading practices, with McReynolds, Sutherland, and Van Devanter joining opinion) (Butler dissents); Advance-Rumely Thresher Co. v. Jackson, 287 U.S. 283 (1932) (upholding state statute granting purchaser of farm equipment a reasonable time to inspect and test equipment, with McReynolds, Sutherland, and Van Devanter joining Butler's opinion); Sproles v. Binford, 286 U.S. 374 (1932) (upholding state statute limiting the size and weight of vehicles, with all Four Horsemen joining opinion); Champlin Ref. Co. v. Corporation Comm'n, 286 U.S. 210 (1932) (upholding state regulation of oil taken from private wells, with McReynolds, Sutherland, and Van Devanter joining Butler's opinion); McCormick \& Co. v. Brown, 286 U.S. 131 (1932) (upholding state regulation of liquor, with all Four Horsemen joining opinion); Packer Corp. v. Utah, 285 U.S. 105 (1932) (upholding state statute limiting cigarette advertising, with all Four Horsemen joining opinion); Hodge Drive-It-Yourself Co. v. Cincinnati, 284 U.S. 335 (1932) (upholding ordinance requiring automobile renters to pay license fees and purchase insurance, with McReynolds, Sutherland, and Van Devanter joining Butler's opinion); Hardware Dealers Mut. Fire Ins. Co. v. Glidden Co., 284 U.S. 151 (1931) (upholding state law requiring insurance companies to submit to arbitration, with all Four Horsemen joining opinion); Abie State Bank v. Bryan, 282 U.S. 765 (1931) (upholding state law assessing state banks for maintenance of common fund to protect depositors, with all Four Horsemen joining opinion); Bain Peanut Co. v. Pinson, 282 U.S. 499 (1931) (upholding state law allowing suits to be brought against corporations in any county in state, with all Four Horsemen joining opinion); Wampler v. LeCompte, 282 U.S. 172 (1930) (upholding state law for preservation of waterfowl and protection of hunters, with all Four Horsemen joining opinion); Corporation Comm'n v. Lowe, 281 U.S. 431 (1930) (rejecting attempt by a producer licensed to operate a cotton gin to enjoin state from licensing a competitor, with all Four Horsemen joining opinion); Cochran v. Board of Educ., 281 U.S. 370 (1930) (upholding state law appropriating money for school books in private and public schools, with all Four Horsemen joining opinion); Miller v. McLaughlin, 281 U.S. 261 (1930) (allowing state that banned fishing in river bordering another state to 
prohibit the possession of certain types of fishing equipment, with all Four Horsemen joining opinion); Carley \& Hamilton, Inc. v. Snook, 281 U.S. 66 (1930) (upholding state placement of fees on certain motor vehicles, with all Four Horsemen joining opinion); Corn Exch. Bank v. Coler, 280 U.S. 218 (1930) (upholding state law allowing state to apply husband's property to the maintenance of his children without his knowledge, with Butler, Sutherland, and Van Devanter joining McReynolds' opinion); Standard Oil Co. v. City of Marysville, 279 U.S. 582 (1929) (upholding city ordinance requiring gasoline tanks to be buried, with all Four Horsemen joining opinion); Leonard \& Leonard v. Earle, 279 U.S. 392 (1929) (Van Devanter, Sutherland, and Butler join McReynolds' opinion upholding state scheme for preserving coastal oyster beds); Foster-Fountain Packing Co. v. Haydel, 278 U.S. 1, 14 (1928) (McReynolds files lone dissent from Butler's opinion striking down state statute which sought to force shrimp producers to pack shrimp within state); Hemphill v. Orloff, 277 U.S. 537 (1928) (holding that a business entity operating in one state cannot perform local business in another without that state's approval, with Butler, Sutherland, and Van Devanter joining McReynolds' opinion); Miller v. Schoene, 276 U.S. 272 (1928) (upholding law requiring destruction of cedar trees infected with disease, with all Four Horsemen joining opinion); Liberty Warehouse Co. v. Tobacco Grower's Coop., 276 U.S. 71 (1928) (upholding state cooperative marketing act, with Butler, Sutherland, and Van Devanter joining McReynolds' opinion); Gorieb v. Fox, 274 U.S. 603 (1927) (upholding power of cities to create zoning districts, with Butler, McReynolds, and Van Devanter joining Sutherland's opinion); Zahn v. Board of Pub. Works, 274 U.S. 325 (1927) (upholding city zoning scheme, with Butler, McReynolds, and Van Devanter joining Sutherland's opinion); Morris v. Duby, 274 U.S. 135 (1927) (upholding state order limiting the weight of trucks in state, with all Four Horsemen joining opinion); Van Oster v. Kansas, 272 U.S. 465 (1926) (upholding state forfeiture law applied to property used in the violation of state liquor laws, with all Four Horsemen joining opinion); Village of Euclid v. Ambler Realty Co., 272 U.S. 365 (1926) (recognizing the broad power of a state to regulate zoning, with Sutherland writing opinion) (Butler, McReynolds, and Van Devanter dissent); Frost \& Frost Trucking Co. v. Railroad Comm'n, 271 U.S. 583 (1926) (upholding state law requiring private carriers for hire to become common carriers, with Butler and Van Devanter joining Sutherland's opinion); Oregon-Wash. R.R. \& Navig. Co. v. Washington, 270 U.S. 87, 103 (1926) (McReynolds and Sutherland dissent from opinion striking down state quarantine law); Cole v. Norborne Land Drainage Dist., 270 U.S. 45 (1926) (upholding state law providing for a drainage district, with all Four Horsemen joining opinion); Kansas City Structural Steel Co. v. Arkansas, 269 U.S. 148 (1925) (upholding state statute placing penalty on business that fails to get a permit to do business in state, with McReynolds, Sutherland, and Van Devanter joining Butler's opinion); New York ex rel. Rosevale Realty Co. v. Kleinert, 268 U.S. 646 (1925) (affirming dismissal of a claim arguing that state zoning plan deprived developer of property in violation of Fourteenth Amendment, with all Four Horsemen joining opinion); Yeiser v. Dysart, 267 U.S. 540 (1925) (upholding power of state to restrict fees lawyers can accept in workmen's compensation cases, with all Four Horsemen joining opinion); George W. Bush \& Sons Co. v. Maloy, 267 U.S. 317, 325 (1925) (McReynolds dissents from opinion, in which Butler, Sutherland, and Van Devanter join, striking down state law requiring common carriers to register with the state in order to use state highways); Buck v. Kuykendall, 267 U.S. 307, 325 (1925) (McReynolds dissents from opinion, in which Butler, Sutherland, and Van Devanter join, striking down state law requiring common carriers to obtain permits before us- 
ing public highways); Merchants Mut. Auto. Liab. Ins. Co. v. Smart, 267 U.S. 126 (1925) (upholding state regulation of insurance providers, with all Four Horsemen joining opinion); Hygrade Provision Co. v. Sherman, 266 U.S. 497 (1925) (upholding state law which imposed criminal penalties on companies misrepresenting foods as Kosher, with Butler, McReynolds, and Van Devanter joining Sutherland's opinion); Hixon v. Oakes, 265 U.S. 254 (1924) (upholding city ordinance prohibiting the filling of prescriptions that contained more than eight ounces of alcohol, with Butler, Sutherland, and Van Devanter joining McReynolds' opinion); Dillingham v. McLaughlin, 264 U.S. 370 (1924) (upholding expansive reading of state banking law, with all Four Horsemen joining opinion); Packard v. Banton, 264 U.S. 140 (1924) (upholding state law requiring every person engaged in business of carrying passengers to have insurance, with Butler, McReynolds, and Van Devanter joining Sutherland's opinion); First Nat'l Bank in St. Louis v. Missouri, 263 U.S. 640 (1924) (upholding right of state to regulate national bank, with McReynolds joining Sutherland's opinion) (Butler and Van Devanter dissent); City of Trenton v. New Jersey, 262 U.S. 182 (1923) (upholding state regulation of water resources, with McReynolds, Sutherland, and Van Devanter joining Butler's opinion); National Union Fire Ins. Co. v. Wanberg, 260 U.S. 71 (1922) (upholding state law placing requirements on insurance companies, with all Four Horsemen joining opinion); Jackman v. Rosenbaum Co., 260 U.S. 22 (1922) (upholding Pennsylvania statute concerning "party walls" which permitted damage to private property without compensation, with McReynolds and Van Devanter joining opinion); Crescent Cotton Oil Co. v. Mississippi, 257 U.S. 129 (1921) (upholding state law regulating the ownership of cotton gins, with McReynolds and Van Devanter joining opinion); Maguire v. Reardon, 255 U.S. 271 (1921) (upholding right of city to demolish building not meeting fire code requirements, with Van Devanter joining McReynolds' opinion); Nicchia v. New York, 254 U.S. 228 (1920) (upholding city ordinance requiring license to own a dog, with Van Devanter joining McReynolds' opinion); Johnson v. Maryland, 254 U.S. 51, 57 (1920) (McReynolds dissents from opinion, in which Van Devanter joins, holding that law requiring drivers to be licensed within state could not apply to post office employees); American Fire Ins. Co. v. King Lumber \& Mfg. Co., 250 U.S. 2 (1919) (upholding state regulation of insurance company's business within state, with McReynolds and Van Devanter joining opinion); Standard Computing Scale Co. v. Farrell, 249 U.S. 571 (1919) (upholding power of state to publish non-binding "specifications" concerning scales, with McReynolds and Van Devanter joining opinion); Corn Prod. Ref. Co. v. Eddy, 249 U.S. 427 (1919) (upholding state product labeling regulation, with McReynolds and Van Devanter joining opinion); Pierce Oil Corp. v. Hope, 248 U.S. 498 (1919) (upholding city ordinance regulating the storage of gasoline, with McReynolds and Van Devanter joining opinion); Merchants Exch. v. Missouri, 248 U.S. 365 (1919) (upholding state law requiring consumers to use state weighers, with McReynolds and Van Devanter joining opinion); Hebe Co. v. Shaw, 248 U.S. 297 (1919) (upholding state statute banning the sale of skim milk, with McReynolds joining opinion); Weigle v. Curtice Bros. Co., 248 U.S. 285 (1919) (upholding state law forbidding the sale of food products containing benzoic acid, with McReynolds and Van Devanter joining opinion); Pure Oil Co. v. Minnesota, 248 U.S. 158 (1918) (upholding state regulation of the transportation of illuminating oils and gasoline through the state, with McReynolds and Van Devanter joining opinion); International \& Great N. Ry. v. Anderson County, 246 U.S. 424 (1918) (upholding state law requiring company to maintain its offices in a certain location, with McReynolds and Van Devanter joining opinion); Sears v. City of Akron, 246 U.S. 242 (1918) 
(upholding power of city to divert water for water supply, with McReynolds and Van Devanter joining opinion); Eiger v. Garrity, 246 U.S. 97 (1918) (upholding state law allowing wife to sue barkeeper for loss of support due to the sale of alcohol to her husband, with McReynolds and Van Devanter joining opinion); Crane v. Campbell, 245 U.S. 304 (1917) (upholding right of state to outlaw the personal possession of liquor, with Van Devanter joining McReynolds' opinion); Farmers Irrig. Dist. v. Nebraska, 244 U.S. 325 (1917) (upholding state court ruling forcing irrigation district to build a bridge over canal for benefit of landowners, with McReynolds and Van Devanter joining opinion); Pennsylvania Fire Ins. Co. v. Gold Issue Mining \& Milling Co., 243 U.S. 93 (1917) (upholding state law forcing those obtaining a business license in state to submit to a power of attorney, with McReynolds and Van Devanter joining opinion); Thomas Cusack Co. v. City of Chicago, 242 U.S. 526 (1917) (upholding municipal ordinance regulating the erection of billboards, with McReynolds and Van Devanter joining opinion); Clark Distilling Co. v. Western Md. Ry. Co., 242 U.S. 311 (1917) (upholding power of state to prevent liquor from being shipped into state, with McReynolds concurring) (Van Devanter dissents); Kane v. New Jersey, 242 U.S. 160 (1916) (affirming conviction of individual for violating state statute requiring non-residents to pay registration fee to use state highways, with McReynolds and Van Devanter joining opinion); Hutchinson Ice Cream Co. v. Iowa, 242 U.S. 153 (1916) (upholding statute regulating sale of products advertised as ice cream, with Van Devanter and McReynolds joining opinion); Pacific Live Stock Co. v. Lewis, 241 U.S. 440 (1916) (upholding power of state to hold administrative hearing to determine water rights, with McReynolds joining Van Devanter's opinion); Armour \& Co. v. North Dakota, 240 U.S. 510 (1916) (upholding conviction of company that failed to sell lard in specified sized containers according to state law, with McReynolds joining Van Devanter's opinion); Butler v. Perry, 240 U.S. 328 (1916) (Van Devanter joins McReynolds' opinion upholding statute requiring every ablebodied man to work six ten-hour days per year on public roads in his county); Carolina Glass Co. v. South Carolina, 240 U.S. 305 (1916) (upholding power of state to allow state commission to determine private company's indebtedness to the state, with Van Devanter joining McReynolds' opinion); Interstate Amusement Co. v. Albert, 239 U.S. 560 (1916) (upholding state law requiring companies to register in state before being able to maintain action in state courts, with McReynolds and Van Devanter joining opinion); Northwestern Laundry v. Des Moines, 239 U.S. 486 (1916) (upholding city statute requiring reductions in smoke emissions, with McReynolds and Van Devanter joining opinion); Miller v. Strahl, 239 U.S. 426 (1915) (upholding state statute requiring hotels to hire a night watchman, with McReynolds and Van Devanter joining opinion); Hadacheck v. Sebastian, 239 U.S. 394 (1915) (upholding ordinance prohibiting brick manufacturing within specified section of municipality, with Van Devanter and McReynolds joining opinion); Price v. Illinois, 238 U.S. 446 (1915) (upholding state pure food law, with McReynolds and Van Devanter joining opinion); Mallinckrodt Chem. Works v. St. Louis, 238 U.S. 41 (1915) (upholding state court revocation of company charter because of failure to disclose involvement in trusts, with McReynolds and Van Devanter joining opinion); Georgia v. Tennessee Copper Co., 237 U.S. 474 (1915) (upholding decree enjoining the discharge of sulfurous fumes that were destroying surrounding vegetation, with Van Devanter joining McReynolds' opinion); Reinman v. City of Little Rock, 237 U.S. 171 (1915) (upholding power of state to regulate livery stables, with McReynolds and Van Devanter joining opinion); South Carolina ex rel. Phoenix Mut. Life Ins. Co. v. McMaster, 237 U.S. 63 (1915) (upholding regulations of state requiring foreign insurance 
corporations to invest in state securities, with McReynolds and Van Devanter joining opinion); Sligh v. Kirkwood, 237 U.S. 52 (1915) (upholding state law prohibiting shipment of citrus fruits that were unfit for consumption, with McReynolds and Van Devanter joining opinion); Hendrick v. Maryland, 235 U.S. 610 (1915) (Van Devanter joins McReynolds' opinion upholding state scheme of licensure and regulation of motor vehicles); Eberle v. Michigan, 232 U.S. 700 (1914) (upholding state regulation of liquor, with Van Devanter joining opinion); Plymouth Coal Co. v. Pennsylvania, 232 U.S. 531 (1914) (upholding state regulation of mining industry, with Van Devanter joining opinion); Hammond Packing Co. v. Montana, 233 U.S. 331 (1914) (upholding state restriction of the manufacture of margarine, with Van Devanter joining opinion); Barrett v. Indiana, 229 U.S. 26 (1913) (upholding state regulation of coal mining industry, with Van Devanter joining opinion); Adams v. City of Milwaukee, 228 U.S. 572 (1913) (upholding municipal milk regulations placing heavier burden on out-of-city producers than on city producers, with Van Devanter joining opinion); Hutchinson v. Valdosta, 227 U.S. 303 (1913) (upholding state regulation of sewer systems and recognizing the ability to impose criminal penalties in order to force compliance, with Van Devanter joining opinion); Rosenthal v. New York, 226 U.S. 260 (1912) (upholding state statute regulating the sale of junk wire, with Van Devanter joining opinion); Purity Extract \& Tonic Co. v. Lynch, 226 U.S. 192 (1912) (upholding state's power to regulate liquors, with Van Devanter joining opinion); Murphy v. California, 225 U.S. 623 (1912) (upholding power of state to regulate occupations that could prove injurious or hazardous to the public, with Van Devanter joining opinion); Standard Stock Food Co. v. Wright, 225 U.S. 540 (1912) (upholding state statute regulating the sale of livestock feed, with Van Devanter joining opinion); Savage v. Jones, 225 U.S. 501 (1912) (upholding state regulation of the sale of livestock feed, with Van Devanter joining opinion); Converse v. Hamilton, 224 U.S. 243 (1912) (upholding state law imposing liability on a stockholder for debts of a corporation of that state and providing for enforcement of such liability, with Van Devanter writing opinion); Williams v. Walsh, 222 U.S. 415 (1912) (upholding state regulation of black powder, with Van Devanter joining opinion); Red " $\mathrm{C}$ " Oil Mfg. Co. v. Board of Agric., 222 U.S. 380 (1912) (upholding state regulation of oil, with Van Devanter joining opinion); Mutual Loan Co. v. Martell, 222 U.S. 225 (1911) (upholding statute regulating assignment of future wages, with Van Devanter joining opinion); Sperry \& Hutchinson Co. v. Rhodes, 220 U.S. 502 (1911) (upholding state regulation requiring consent for the use of portraits, with Van Devanter joining opinion); Lindsley v. National Carbonic Gas Co., 220 U.S. 61 (1911) (upholding a state law limiting landowner's ability to pump resources from his own land, with Van Devanter writing opinion).

${ }^{57}$ See, e.g., Beal v. Missouri Pac. R.R., 312 U.S. 45 (1941) (denying injunction to limit state law requiring certain number of employees on train, with McReynolds joining in part and dissenting in part); Atchison, T. \& S.F.R.R. v. Railroad Comm'n, 283 U.S. 380 (1931) (recognizing power of the state to require interstate carrier to construct passenger station, with Butler, Sutherland, and Van Devanter joining opinion) (McReynolds dissents); Missouri Pac. R.R. v. Norwood, 283 U.S. 249 (1931) (declining to review state law which regulated the size of freight trains and switching crews, with McReynolds, Sutherland, and Van Devanter joining Butler's opinion); New Orleans Pub. Serv. v. City of New Orleans, 281 U.S. 682 (1930) (holding that city regulation did not amount to a taking, with McReynolds, Sutherland, and Van Devanter joining Butler's opinion); Broad River Power Co. v. South Carolina, 281 U.S. 537 (1930) (upholding state regulation preventing corporation from ceasing op- 
eration of railway, with all Four Horsemen joining opinion); Nashville, C. \& S. Ry. v. White, 278 U.S. 456 (1929) (refusing to strike down state regulation requiring posting of flagmen, with all Four Horsemen joining opinion); Missouri-Kan.-Tex. R.R. v. Mars, 278 U.S. 258 (1929) (upholding state law requiring railroad to pay the debts of acquired railroad, with McReynolds, Sutherland, and Van Devanter joining Butler's opinion); Lehigh Valley R.R. v. Board of Pub. Util. Comm'rs, 278 U.S. 24 (1928) (upholding state commission's setting of safety specification for railroad crossing, with Butler, Sutherland, and Van Devanter joining opinion) (McReynolds dissents); Fort Smith Light \& Traction Co. v. Paving Dist. No. 16, 274 U.S. 387 (1927) (upholding power of state to amend corporate charters, with all Four Horsemen joining opinion); Peoples Natural Gas Co. v. Public Serv. Comm'n, 270 U.S. 550 (1926) (holding that gas pipeline which transported gas for intrastate consumption was under regulation of state, with Butler, McReynolds, and Sutherland joining Van Devanter's opinion); New York ex rel. Woodhaven Gas Light Co. v. Public Serv. Comm'n, 269 U.S. 244 (1925) (upholding state regulation requiring gas company to extend pipelines, with McReynolds, Sutherland, and Van Devanter joining Butler's opinion); Western \& Atl. R.R. v. Georgia Pub. Serv. Comm'n, 267 U.S. 493 (1925) (upholding power of state to require railroad to operate switching service, with all Four Horsemen joining opinion); Fort Smith Light \& Traction Co. v. Bourland, 267 U.S. 330 (1925) (upholding state order requiring street car company to continue operation of line, with all Four Horsemen joining opinion); Norfolk \& W. Ry. v. Public Serv. Comm'n, 265 U.S. 70 (1924) (upholding state's power to require railroad to construct a crossing for vehicles across railroad tracks, with McReynolds, Sutherland, and Van Devanter joining Butler's opinion); Durham Pub. Serv. Co. v. City of Durham, 261 U.S. 149 (1923) (expansively reading a state's power to tax and regulate corporations, with Butler, Sutherland, and Van Devanter joining McReynolds' opinion); Southern Ry. v. Clift, 260 U.S. 316 (1922) (upholding state law requiring railroads to pay or reject claims for property damage or treat them as liabilities owed, with all Four Horsemen joining opinion); Pierce Oil Corp. v. Phoenix Ref. Co., 259 U.S. 125 (1922) (upholding state corporation commission requirement that a foreign corporation operate its local, private oil pipeline as a common carrier, with Van Devanter and McReynolds joining opinion); Pacific Gas \& Elec. Co. v. Police Court, 251 U.S. 22 (1919) (upholding ordinance requiring street railway company to sprinkle the street occupied by the railroad in order to control dust, with Van Devanter and McReynolds joining opinion); Southern Pac. Ry. v. Arizona, 249 U.S. 472 (1919) (upholding fine against railroad because railroad refused to carry certain cargo on line, with McReynolds and Van Devanter joining opinion); Lake Erie \& W.R.R. v. State Pub. Util. Comm'n, 249 U.S. 422 (1919) (McReynolds joins Van Devanter opinion upholding state commission's order requiring railroad to restore a siding); Chicago \& N.W. Ry. v. Ochs, 249 U.S. 416 (1919) (upholding state commission order forcing railroad to build track to a plant, with McReynolds joining Van Devanter's opinion); Great N. Ry. v. Minnesota ex rel. Clara City, 246 U.S. 434 (1918) (upholding state requirement that railroad build sidewalk across line, with McReynolds and Van Devanter joining opinion); City of Mitchell v. Dakota Cent. Tel. Co., 246 U.S. 396 (1918) (upholding local ordinance forcing telephone company to remove its local service, with McReynolds and Van Devanter joining opinion); Gulf, $\mathrm{C}$. \& S. Ry. v. Texas, 246 U.S. 58 (1918) (upholding state order requiring train to stop at certain city, with Van Devanter joining opinion); New York ex rel. New York \& Queens Gas Co. v. McCall, 245 U.S. 345 (1917) (upholding state order requiring gas company to extend gas lines, with McReynolds and Van Devanter joining opinion); 
Seaboard Air Line Ry. v. North Carolina, 245 U.S. 298 (1917) (upholding WebbKenyon Act allowing states to prevent common carriers from importing alcohol into the state, with McReynolds writing opinion) (Van Devanter dissents); Sutton v. New Jersey, 244 U.S. 258 (1917) (upholding state law requiring street cars to carry police officers, with McReynolds and Van Devanter joining opinion); Rome Ry. \& Light Co. v. Floyd County, 243 U.S. 257 (1917) (upholding order of county forcing railroad to pay for part of new bridge, with McReynolds and Van Devanter joining opinion); Chesapeake \& Ohio Ry. v. Public Serv. Comm'n, 242 U.S. 603 (1917) (refusing to suspend order of state commission forcing railroad to install service trains on route, with McReynolds joining Van Devanter's opinion); Lake Shore \& Michigan S. Ry. v. Clough, 242 U.S. 375 (1917) (affirming state order forcing railroad to pay for drainage projects, with McReynolds and Van Devanter joining opinion); Chicago, T. \& S.E. Ry. v. Anderson, 242 U.S. 283 (1916) (upholding award to plaintiff against railroad because of railroad's failure to remove weeds from property as required, with McReynolds and Van Devanter joining opinion); Vandalia R.R. v. Public Serv. Comm'n, 242 U.S. 255 (1916) (upholding state order requiring trains to have headlights of certain power, with McReynolds and Van Devanter joining opinion); Seaboard Air Line Ry. v. City of Raleigh, 242 U.S. 15 (1916) (affirming city ordinance directing railroad to remove track from city sidewalk, with McReynolds and Van Devanter joining opinion); Detroit \& Mackinac Ry. v. Michigan R.R. Comm'n, 240 U.S. 564 (1916) (upholding state order requiring railroad to relay track, with Van Devanter writing opinion) (McReynolds concurs in result); Seaboard Air Line Ry. v. Railroad Comm'n, 240 U.S. 324 (1916) (upholding state order requiring railroad to connect track between two points, with Van Devanter joining McReynolds' opinion); Phoenix Ry. v. Geary, 239 U.S. 277 (1915) (upholding state order requiring railroad to double track its rail lines, with McReynolds and Van Devanter joining opinion); Chicago \& Alton R.R. v. Tranbarger, 238 U.S. 67 (1915) (upholding judgment against railroad for failing to construct drainage ways as required, with McReynolds and Van Devanter joining opinion); Michigan Cent. R.R. v. Michigan R.R. Comm'n, 236 U.S. 615 (1915) (upholding power of state to require railroads to connect lines, with Van Devanter joining opinion); Wadley S. Ry. v. Georgia, 235 U.S. 651 (1915) (upholding power of state to impose penalties for violations of orders of public utilities commissions, with Van Devanter joining opinion); South Covington \& C. St. Ry. v. City of Covington, 235 U.S. 537 (1915) (upholding power of state to regulate fumigation, ventilation, and cleanliness of railroad cars in the absence of federal legislation, with Van Devanter joining opinion); Missouri Pac. Ry. v. City of Omaha, 235 U.S. 121 (1914) (upholding power of state to require railroad to construct viaducts over tracks, with Van Devanter joining opinion); Atlantic Coast L.R.R. v. Georgia, 234 U.S. 280 (1914) (upholding state statute requiring railroads to use a certain type of headlight, with Van Devanter joining opinion); Chicago, M. \& St. P. Ry. v. Iowa, 233 U.S. 334 (1914) (upholding power of state to require railroad to carry pre-loaded rail cars, with Van Devanter joining opinion); Kansas City S. Ry. v. Anderson, 233 U.S. 325 (1914) (upholding power of state to impose double damages against railroad for failure to pay certain injury awards, with Van Devanter joining opinion); Atlantic Coast L.R.R. v. City of Goldsboro, 232 U.S. 548 (1914) (upholding power of city to enact regulations of rail service, with Van Devanter joining opinion); Chicago, M. \& St. P. Ry. v. City of Minneapolis, 232 U.S. 430 (1914) (upholding state law requiring railroads to abolish grade crossings and build viaducts at their own expense, with Van Devanter joining opinion); Grand T. Ry. v. Michigan R.R. Comm'n, 231 U.S. 457 (1913) (upholding commission order requiring railroads to use tracks for the inter- 
change of interstate traffic, with Van Devanter joining opinion); Yazoo \& Miss. Valley R.R. v. Jackson Vinegar Co., 226 U.S. 217 (1912) (upholding state statute requiring common carriers to settle claims for lost freight within sixty days, with Van Devanter writing opinion); Western Union Tel. Co. v. City of Richmond, 224 U.S. 160 (1912) (upholding state and municipal ordinances regulating use of streets by public service corporation, with Van Devanter joining opinion); Western Union Tel. Co. v. Crovo, 220 U.S. 364 (1911) (upholding state law imposing a penalty on telegraph company for negligently failing to transmit a message promptly, with Van Devanter joining opinion).

s8 See, e.g., Bell Tel. Co. v. Pennsylvania Pub. Util. Comm'n, 309 U.S. 30 (1940) (per curiam) (dismissing appeal brought by telephone company to enjoin revision of state telephone rates, with McReynolds joining opinion); American Toll Bridge Co. v. Railroad Comm'n, 307 U.S. 486 (1939) (affirming state order lowering toll rates, with McReynolds joining Butler's opinion); Driscoll v. Edison Light \& Power Co., 307 U.S. 104 (1939) (reversing lower court ruling restraining temporary rate order, with Butler and McReynolds joining opinion); Petroleum Expl'r. Inc. v. Public Serv. Comm'n, 304 U.S. 209 (1938) (dismissing complaint brought by petroleum company to prevent state from investigating gasoline rates, with Butler joining opinion) (McReynolds concurs in result); Natural Gas Pipeline Co. v. Slattery, 302 U.S. 300 (1937) (holding that foreign corporation can be required to give information to state tribunal where such did not impede commerce or was not overtaken by Congress, with Butler, McReynolds and Sutherland joining opinion); Townsend v. Yeomans, 301 U.S. 441 (1937) (upholding state regulation of rates charged by tobacco warehousemen, with all Four Horsemen joining opinion); Midland Realty Co. v. Kansas City Power \& Light Co., 300 U.S. 109 (1937) (upholding power of state to supersede rates previously established by contract, with McReynolds, Sutherland, and Van Devanter joining Butler's opinion); Hegeman Farms Corp. v. Baldwin, 293 U.S. 163 (1934) (rejecting contention by milk dealer that profit allowed by state was insufficient to cover operations, with Butler, McReynolds, and Van Devanter joining opinion) (Sutherland concurs); Dayton Power \& Light Co. v. Public Util. Comm'n, 292 U.S. 290 (1934) (ruling that gas company failed to meet its burden of showing commission's ruling was arbitrary) (Butler and McReynolds concur) (Sutherland and Van Devanter take no part); Lindheimer v. Illinois Bell Tel. Co., 292 U.S. 151 (1934) (ruling that rate set by state for telephone service was not confiscatory, with McReynolds, Sutherland, and Van Devanter joining opinion) (Butler concurs); Clark's Ferry Bridge Co. v. Public Serv. Comm'n, 291 U.S. 227 (1934) (sustaining state order limiting rates to be charged by toll bridge company, with all Four Horsemen joining opinion); Los Angeles Gas \& Elec. Co. v. Railroad Comm'n, 289 U.S. 287 (1933) (ruling that burden was on challenger to prove that a rate was confiscatory, with McReynolds joining opinion) (Butler dissents with Sutherland joining dissenting opinion) (Van Devanter takes no part); Public Serv. Comm'n v. Great N. Util. Co., 289 U.S. 130 (1933) (upholding commission order prescribing specific rates, with McReynolds, Sutherland, and Van Devanter joining Butler's opinion); Public Serv. Comm'n v. Wisconsin Tel. Co., 289 U.S. 67 (1933) (vacating a lower court's decree granting an interlocutory injunction restraining the order of a state's public service commission reducing telephone rates, with all Four Horsemen joining opinion); Wabash Valley Elec. Co. v. Young, 287 U.S. 488 (1933) (rejecting claim of utility that rate set by state was confiscatory, with Butler, McReynolds, and Van Devanter joining Sutherland's opinion); Stephenson v. Binford, 287 U.S. 251 (1932) (upholding state statute regulating private contract carriers and their use of highways, with 
McReynolds and Van Devanter joining Sutherland's opinion) (Butler dissents); Western Dist. Co. v. Public Serv. Comm'n, 285 U.S. 119 (1932) (granting states greater leeway in forcing utilities to show that out of state supplier rates were reasonable, with all Four Horsemen joining opinion); Board of R.R. Comm'rs v. Great N. Ry. 281 U.S. 412 (1930) (holding that federal courts will not interfere with railroad rates established by a state for its internal commerce on the ground that they discriminate against interstate commerce until such discrimination has been found by the ICC, with all Four Horsemen joining opinion); National Fire Ins. Co. v, Thompson, 281 U.S. 331 (1930) (rejecting insurance company suit seeking to enjoin state rate order, with McReynolds, Sutherland, and Van Devanter joining Butler's opinion); Gilchrist v. Interborough Rapid Trans. Co., 279 U.S. 159 (1929) (holding that railway suit to enjoin state from imposing rate could not yet be entertained, with McReynolds writing opinion) (Van Devanter, Sutherland, and Butler dissent); Sutter Butte Canal Co. v. Railroad Comm'n, 279 U.S. 125 (1929) (upholding power of state to modify rates charged by a public utility for water, with all Four Horsemen joining opinion); United Fuel Gas Co. v. Railroad Comm'n, 278 U.S. 300 (1929) (limiting ability of companies to challenge confiscatory rates, with Butler, Sutherland, and Van Devanter joining opinion) (McReynolds concurs); Aetna Ins. Co. v. Hyde, 275 U.S. 440 (1928) (upholding state insurance rate cut, with McReynolds, Sutherland, and Van Devanter joining Butler's opinion); Stimson Lumber Co. v. Kuykendall, 275 U.S. 207 (1927) (upholding right of state to regulate tugboat rates, with McReynolds, Sutherland, and Van Devanter joining Butler's opinion); Arkansas R.R. Comm'n v. Chicago, R.I. \& Pac. R.R., 274 U.S. 597 (1927) (granting state greater power to set intrastate rail rates, with all Four Horsemen joining opinion); Board of Pub. Util. Comm'rs v. New York Tel. Co., 271 U.S. 23 (1926) (upholding state imposition of rates on telephone company, with McReynolds, Sutherland, and Van Devanter joining Butler's opinion); Live Oak Water Users' Ass'n v. Railroad Comm'n, 269 U.S. 354 (1926) (limiting power of court to review decision of state court upholding rate fixing order, with Butler, Sutherland, and Van Devanter joining McReynolds' opinion); Ortega Co. v. Triay, 260 U.S. 103 (1922) (holding that state was not barred from ordering railroad to increase its rates, with all Four Horsemen joining opinion); Witchita R.R. \& Light Co. v. Public Util. Comm'n, 260 U.S. 48 (1922) (holding that state may delegate legislative power to administrative boards to deal with rate schedules, with all Four Horsemen joining opinion); Galveston Elec. Co. v. City of Galveston, 258 U.S. 388 (1922) (holding that profits based on rate set by municipality were adequate, with McReynolds and Van Devanter joining opinion); Oklahoma Natural Gas Co. v. Oklahoma, 258 U.S. 234 (1922) (holding that company was not deprived of due process by state reducing rates because of poor service, with McReynolds and Van Devanter joining opinion); Springfield Gas \& Elec. Co. v. City of Springfield, 257 U.S. 66 (1921) (upholding state law permitting city to own electric plant and set its own rate, against claim that it violated the Fourteenth Amendment rights of competing power plant regulated by the state, with McReynolds and Van Devanter joining opinion); Missouri Pac. Ry. v. McGrew Coal Co., 256 U.S. 134 (1921) (mem.) (holding that overcharges placed on railroad will stand where statute under which they were imposed was constitutional, with McReynolds and Van Devanter joining opinion); Pennsylvania Gas Co. v. Public Serv. Comm'n, 252 U.S. 23 (1920) (holding that state may regulate interstate gas rates where Congress has not acted, with McReynolds and Van Devanter joining opinion); Producers Transp. Co. v. Railroad Comm'n, 251 U.S. 228 (1920) (upholding state law holding that anyone who owns pipeline for public benefit was under state regulation as a common carrier, 
with McReynolds joining Van Devanter's opinion); St. Louis, l. Mtn. \& S. Ry. v. Williams, 251 U.S. 63 (1919) (upholding penalty enacted by state against railroad for violating state rate provision, with Van Devanter writing opinion) (McReynolds dissents); Lincoln Gas \& Elec. Co. v. City of Lincoln, 250 U.S. 256 (1919) (upholding dismissal of suit against city to enjoin enforcement of rate lowering ordinance, with McReynolds and Van Devanter joining opinion); Columbus Ry. Power \& Light Co. v. City of Columbus, 249 U.S. 399 (1919) (holding that railroad could not be let out of contract with city because of unforeseen costs due to war, with McReynolds and Van Devanter joining opinion); Public Util. Comm'n v. Landon, 249 U.S. 236 (1919) (upholding price regulation imposed by public utilities board on gas company, with Van Devanter joining McReynolds' opinion); Union Dry Goods Co. v. Georgia Pub. Serv. Corp., 248 U.S. 372 (1919) (upholding state price fixing of electricity rates, with McReynolds and Van Devanter joining opinion); Chicago, Milwaukee \& St. Paul Ry. v. Minneapolis Civie \& Commerce Ass'n, 247 U.S. 490 (1918) (affirming state commission ruling ordering rail companies to discontinue certain charges, with McReynolds and Van Devanter joining opinion); Illinois Cent. R.R. v. State Pub. Util. Comm'n, 245 U.S. 493 (1918) (affirming dismissal of bills against state commission that ordered lowering of rates for railroad routes, with McReynolds joining Van Devanter's opinion); Pennsylvania R.R. v. Towers, 245 U.S. 6 (1917) (dismissing suit seeking to enjoin order of state commission requiring certain rates for rail tickets, with Van Devanter joining opinion) (McReynolds dissents); Puget Sound Traction, Light \& Power Co. v. Reynolds, 244 U.S. 574 (1917) (denying injunction against state utilities commission order requiring through service at a certain rate, with Van Devanter joining opinion) (McReynolds dissents); Darnell v. Edwards, 244 U.S. 564 (1917) (dismissing bill to seek injunction against state order setting rates, with McReynolds and Van Devanter joining opinion); Missouri Pac. Ry. v. McGrew Coal Co., 244 U.S. 191 (1917) (upholding state law preventing railroad from charging more for short hauls than longer hauls, with Van Devanter joining McReynolds' opinion); Van Dyke v. Geary, 244 U.S. 39 (1917) (upholding power of state to regulate individual who owned water system used by community, with Van Devanter joining opinion) (McReynolds dissents); Newark Natural Gas \& Fuel Co. v. City of Newark, 242 U.S. 405 (1917) (upholding municipal rate structure ordinance, with McReynolds and Van Devanter joining opinion); Chicago, M. \& St. P. Ry. v. State Pub. Util. Comm'n, 242 U.S. 333 (1917) (upholding state utilities commission order setting railroad rates, with McReynolds and Van Devanter joining opinion); Missouri v. Chi., B. \& Q.R.R., 241 U.S. 533 (1916) (striking railroad defense of confiscation in action by state to recover back rates, with MeReynolds and Van Devanter joining opinion); Terminal Taxicab Co. v. Kutz, Newman \& Brownlow, 241 U.S. 252 (1916) (holding that company was within jurisdiction of District of Columbia regulatory board, and upholding two of three types of rate regulation, with McReynolds and Van Devanter joining opinion); Milwaukee Elec. Ry. \& Light Co. v. Railroad Comm'n, 238 U.S. 174 (1915) (dismissing complaint seeking to prevent enforcement of railroad commission order setting street railway rates, with McReynolds and Van Devanter joining opinion); Des Moines Gas Co. v. City of Des Moines, 238 U.S. 153 (1915) (affirming dismissal of suit seeking injunction against city order fixing gas rates, with McReynolds and Van Devanter joining opinion); New Orleans Tax Payers' Protective Ass'n v. Sewerage \& Water Bd., 237 U.S. 33 (1915) (upholding state law and city ordinance establishing rates for drinking water, with McReynolds and Van Devanter joining opinion); Louisville \& Nash. R.R. v. Finn, 235 U.S. 601 (1915) (upholding state order setting railroad rates, with Van Devanter joining opinion); Port Richmond \& Bergen 
Point Ferry Co. v. Board of Chosen Freeholders, 234 U.S. 317 (1914) (upholding ordinance fixing rates on ferry service, with Van Devanter joining opinion); Louisville \& Nash. R.R. v. Garrett, 231 U.S. 298 (1913) (upholding state delegation to railroad commission of railroad rate oversight, with Van Devanter joining opinion); Wood $v$. Vandalia R.R., 231 U.S. 1 (1913) (ruling that rate fixed by state will not be ruled confiscatory in absence of proof of value of intrastate property and interstate business, with Van Devanter joining opinion); Allen v. St. Louis, I. Mtn. \& S. Ry., 230 U.S. 553 (1913) (upholding right of state to set intrastate rail rates, with Van Devanter joining opinion); Southern Pac. Co. v. Campbell, 230 U.S. 537 (1913) (holding that allegations in bill were insufficient to show that rate set by state was confiscatory, with Van Devanter joining opinion); Portland Ry., Light \& Power Co. v. Railroad Comm'n, 229 U.S. 397 (1913) (upholding right of state to set street railway fare rates, with Van Devanter joining opinion); Murray v. City of Pocatello, 226 U.S. 318 (1912) (upholding state statute establishing fixed water rates, with Van Devanter joining opinion); City of Louisville v. Cumberland Tel. \& Tel. Co., 225 U.S. 430 (1912) (holding that Court requires clear evidence before it will rule rate confiscatory, with Van Devanter joining opinion).

${ }^{59}$ See, e.g., Funkhouser v. Preston Co., 290 U.S. 163 (1933) (holding that a state had not violated the Contracts Clause by requiring interest to be added to recoveries in actions for unliquidated damages caused by a breach of contract, with all Four Horsemen joining opinion); Hawks v. Hamill, 288 U.S. 52 (1933) (ruling that state interference with agreement made with toll bridge owners did not violate the Contracts Clause, with all Four Horsemen joining opinion); Shriver v. Woodbine Sav. Bank, 285 U.S. 467 (1932) (rejecting stockholder's argument that a state law violated the Contracts Clause by placing upon him an obligation to pay assessments that did not exist when he purchased the stock, with all Four Horsemen joining opinion); Kirk v. Maumee Valley Elec. Co., 279 U.S. 797 (1929) (holding that state had not violated Contracts Clause by requiring company to relinquish part of a canal the state authorized for its use, with all Four Horsemen joining opinion); Larson v. South Dakota, 278 U.S. 429 (1929) (holding that state's building of a free bridge after granting exclusive license to ferry franchise company did not violate Contracts Clause, with all Four Horsemen joining opinion); Millsaps College v. City of Jackson, 275 U.S. 129 (1927) (Van Devanter, Sutherland, and Butler join McReynolds' opinion upholding property tax against Contracts Clause challenge); Western Union Tel. Co. v. Georgia, 269 U.S. 67 (1925) (holding state law allowing state more easily to assert its title to property did not violate Contracts Clause, with all Four Horsemen joining opinion); Fleming v. Fleming, 264 U.S. 29 (1924) (stating that Contracts Clause applies to legislative and not judicial action, with all Four Horsemen joining opinion); Tidal Oil Co. v. Flanagan, 263 U.S. 444 (1924) (declaring as well settled the rule that a state court's decision to overturn an earlier case which interferes with losing party's property rights does not violate the Contracts Clause, with all Four Horsemen joining opinion); Security Sav. Bank v. California, 263 U.S. 282 (1923) (upholding as not violative of the Contracts Clause a state law requiring unclaimed savings banks deposits to escheat to state, with all Four Horsemen joining opinion); New York ex rel. Clyde v. Gilchrist, 262 U.S. 94 (1923) (stating that the Court will be wary of overturning state court decisions concerning matters of local policy, like systems of taxation, as violating the Contracts Clause, with all Four Horsemen joining opinion); Arkansas Natural Gas Co. v. Arkansas R.R. Comm'n, 261 U.S. 379 (1923) (ruling that state has the power to modify certain contracts when it was in the public's interest, with Butler, McReynolds, and Van Devanter joining Sutherland's opinion); Colum- 
bia Ry., Gas \& Elec. Co. v. South Carolina, 261 U.S. 236 (1923) (ruling that Contracts Clause affords no protection from impairment of obligation through judicial decision, with Butler, McReynolds, and Van Devanter joining Sutherland's opinion); Rooker v. Fidelity Trust Co., 261 U.S. 114 (1923) (ruling that Contracts Clause affords no protection from impairment of obligation through judicial decision, with Butler, McReynolds, and Sutherland joining Van Devanter's opinion); Conley v. Barton, 260 U.S. 677 (1923) (upholding legislature's power to modify or change existing remedies or procedure without impairing rights of contract, as long as substantial remedy remains, with all Four Horsemen joining opinion); Galveston Wharf Co. v. City of Galveston, 260 U.S. 473 (1923) (limiting the cases protected by the Contracts Clause, with all Four Horsemen joining opinion); Detroit United Ry. v. City of Detroit, 255 U.S. 171 (1921) (holding a city's requirement that railway company remove track once its charter expires did not violate the Contracts Clause, with McReynolds and Van Devanter joining opinion); Thornton v. Duffy, 254 U.S. 361 (1920) (holding that a state law withdrawing employer's alternative of self-insuring against liability for workmen's compensation did not violate the Contracts Clause, with Van Devanter joining opinion) (McReynolds dissents); International Bridge Co. v. New York, 254 U.S. 126 (1920) (upholding New York amendment to charter that required the company to provide a roadway and path for pedestrians on its railroad bridge between New York and Canada, with Van Devanter joining opinion) (McReynolds dissents); Troy U.R.R. v. Mealy, 254 U.S. 47 (1920) (deferring to state court finding that exemption from taxes was privilege, not contract right protected by Constitution, with Van Devanter and McReynolds joining opinion); Munday v. Wisconsin Trust Co., 252 U.S. 499 (1920) (Van Devanter joins McReynolds upholding statute regulating capacity of foreign corporations to acquire property in the state against Contracts Clause challenge); Milwaukee Electric Ry. v. City of Milwaukee, 252 U.S. 100 (1920) (upholding regulation of street railway company against Contracts Clause challenge, with Van Devanter joining opinion) (McReynolds dissents); Hardin-Wyandot Lighting Co. v. Upper Sandusky, 251 U.S. 173 (1919) (upholding power of municipality to limit and regulate street lights against Contracts Clause challenge, with Van Devanter and McReynolds joining opinion); Bank of Oxford v. Love, 250 U.S. 603 (1919) (Van Devanter joins McReynolds' opinion upholding state regulation of banks against Contracts Clause challenge); City of Pawhuska v. Pawhuska Oil \& Gas Co., 250 U.S. 394 (1919) (McReynolds joins Van Devanter's opinion upholding state regulation of gas rates against Contracts Clause challenge); Missouri \& Ark. Lumber \& Mining Co. v. Sebastain County, 249 U.S. 170 (1919) (Van Devanter joins McReynolds' opinion upholding state's power to cancel interest on certain judgments); McCoy v. Union Elev. R.R., 247 U.S. 354 (1918) (Van Devanter joins McReynolds' opinion holding that the Contracts Clause does not relate to judicial action impairing the obligation of contracts); Contributors to Pennsylvania Hosp. v. City of Philadelphia, 245 U.S. 20 (1917) (holding that state eminent domain power was not divested by contract with hospital and the contract did not fall within the protection of the Contracts Clause, with McReynolds and Van Devanter joining opinion); Morris Canal \& Banking Co. v. Baird, 239 U.S. 126 (1915) (Van Devanter joins McReynolds' opinion upholding state taxation of canal company against Contracts Clause challenge); Southern Pac. Co. v. Portland, 227 U.S. 559 (1913) (holding that city preventing the use of locomotives and freight hauling on tracks laid under city franchise did not violate the Contracts Clause, with Van Devanter joining opinion); Texas \& N.O.R.R. v. Miller, 221 U.S. 408 (1911) (Van Devanter writes opinion holding that wrongful death statute repealing the immunity from such suits conferred by the company's charter did not 
violate the Contracts Clause); Shawnee Sewerage \& Drainage Co. v. Stearns, 220 U.S. 462 (1911) (holding that a breach of contract by a municipality did not violate the Contracts Clause, with Van Devanter joining opinion). See also Veix v. Sixth Ward Bldg. \& Loan Ass'n., 310 U.S. 32 (1940) (McReynolds concurs in result of opinion upholding statute curtailing rights of certificate holders to make withdrawals from savings and loans); Honeyman v. Jacobs, 306 U.S. 539 (1939) (upholding limitation to mortgagee's deficiency judgment after a foreclosure, with McReynolds and Butler joining opinion); Peoples Banking Co. v. Sterling, 300 U.S. 175 (1937) (holding that a change in state law concerning the remedies available against bank stockholders did not violate the Contracts Clause, with all Four Horsemen joining opinion); Richmond Mortgage \& Loan Corp. v. Wachovia Bank \& Trust Co., 300 U.S. 124 (1937) (upholding state law giving protection to debtors, with all Four Horsemen joining opinion); Doty v. Love, 295 U.S. 64 (1935) (holding that a state law providing for the reorganization rather than liquidation of insolvent banks did not violate the Contracts Clause, with all Four Horsemen joining opinion); United States Mortgage Co. v. Matthews, 293 U.S. 232 (1934) (rejecting challenge to statute curtailing mortgagee's rights to summary remedies during periods of declared emergency, with Van Devanter, Sutherland, and Butler joining McReynolds' opinion); - District of Columbia v. Andrew Paper Co., 256 U.S. 582 (1921) (holding that grants of vaults under D.C. sidewalks were revocable licenses and D.C. could assess rent against them, with Van Devanter and McReynolds joining opinion); Long Sault Dev. Co. v. Call, 242 U.S. 272 (1916) (affirming court decision upholding N.Y. law which revoked a contract given to create dams, with McReynolds and Van Devanter joining opinion).

60348 U.S. 483 (1955).

${ }^{61} 279$ U.S. 337 (1929).

62 Id. at $339-340$.

${ }^{63}$ See, e.g., Clason v. Indiana, 306 U.S. 439 (1939) (Butler joins McReynolds' opinion upholding animal disposal licensing statute against dormant Commerce Clause challenge); McNutt v. General Motors Acceptance Corp., 298 U.S. 178 (1936) (all Four Horsemen join opinion dismissing, on jurisdictional grounds, suit seeking to enjoin the enforcement of a statute regulating and requiring a license for the business of purchasing contracts arising out of retail installment sales); Stanley v. Public Util. Comm'n, 295 U.S. 76 (1935) (per curiam) (all Four Horsemen join opinion upholding state scheme for licensing and regulating intrastate carriers for hire on state highways); Grubb v. Public Util. Comm'n, 281 U.S. 470 (1930) (McReynolds, Sutherland, and Butler join Van Devanter's opinion upholding as res judicata a state public utilities commission's licensing scheme for passenger buses against dormant Commerce Clause and privileges and immunities challenges); Herbring v. Lee, 280 U.S. 111 (1929) (all Four Horsemen join opinion declining to reach constitutional challenge to state law requiring foreign fire insurance companies to do local business through licensed local agents and regulating the number of agents that may be appointed in a given city); Bothwell v. Buckbee, Mears Co., 275 U.S. 274 (1927) (all Four Horsemen join opinion upholding a state statute requiring foreign insurance companies to obtain licenses to solicit and do business within the state); Hayman v. City of Galveston, 273 U.S. 414 (1927) (all Four Horsemen join opinion upholding state hospital's exclusion of osteopaths); Interstate Busses Corp. v. Holyoke St. Ry., 273 U.S. 45 (1927) (Van Devanter, McReynolds, and Sutherland join Butler's opinion upholding state law requiring a license and a certificate of public convenience and necessity for intrastate carriage of passengers for hire on public highways); Graves v. Minnesota, 272 
U.S. 425 (1926) (all Four Horsemen join opinion upholding state scheme of licensing dentists); Lehmann v. State Bd. of Pub. Accountancy, 263 U.S. 394 (1923) (all Four Horsemen join opinion upholding statute giving private board power to grant certificates of registration to persons deemed qualified to practice as Certified Public Accountants, and to decertify any accountant it deems unfit); Douglas v. Noble, 261 U.S. 165 (1923) (all Four Horsemen join opinion upholding statute delegating to a board of practicing dentists power to grant licenses, set professional standards and rules of conduct, and to bar those dentists deemed unfit); LaTourette v. McMaster, 248 U.S. 465 (1919) (Van Devanter and McReynolds join opinion upholding statute requiring those licensed as insurance brokers to be state residents and to have been licensed insurance agents of the state for at least two years); Payne v. Kansas ex rel. Brewster, 248 U.S. 112 (1918) (Van Devanter joins McReynolds' opinion upholding statute forbidding sale of farm produce on commission without a license); Watters $v$. Michigan, 248 U.S. 65 (1918) (Van Devanter and McReynolds join opinion upholding conviction under ordinance requiring a license to peddle goods according to state law); Merrick v. Halsey \& Co., 242 U.S. 568 (1917) (Van Devanter joins opinion upholding statute regulating securities dealers and requiring them to be licensed) (McReynolds dissents); Caldwell v. Sioux Falls Stock Yards Co., 242 U.S. 559 (1917) (Van Devanter joins opinion upholding statute regulating securities dealers and requiring them to be licensed) (McReynolds dissents); Hall v. Geiger-Jones Co., 242 U.S. 539 (1917) (Van Devanter joins opinion upholding statute regulating securities dealers and requiring them to be licensed) (McReynolds dissents); Crane v. Johnson, 242 U.S. 339 (1917) (Van Devanter and McReynolds join opinion upholding state scheme for licensing "drugless" healers); McNaughton v. Johnson, 242 U.S. 344 (1917) (Van Devanter and McReynolds join opinion upholding state scheme for licensing optometrists and ophthalmologists); Lehon v. City of Atlanta, 242 U.S. 53 (1916) (Van Devanter and McReynolds join opinion upholding ordinance for licensing and regulating private detectives); Toyota v. Territory of Hawaii, 226 U.S. 184 (1912) (Van Devanter joins opinion upholding statute regulating licensing of auctioneers). See generally Lawrence $M$. Friedman, Freedom of Contract and Occupational Licensing, 1890-1910: A Legal and Social Study, 53 Cal. L. Rev. 487 (1965) (surveying occupational licensing jurisprudence in period just prior to the tenures of the Four Horsemen).

* Tyson \& Brother-United Theatre Ticket Offices v. Banton, 273 U.S. 418 (1927).

65 Weller v. New York, 268 U.S. 319 (1925) (McReynolds, J.).

${ }^{65}$ Compare Ribnik v. McBride, 277 U.S. 350 (1928) (Van Devanter, McReynolds, and Butler join Sutherland's opinion striking down New Jersey statute regulating fees charged by employment agencies) and Adams v. Tanner, 244 U.S. 590 (1917) (Van Devanter joins McReynolds' opinion invalidating Washington law banning employment agencies) with Brazee v. Michigan, 241 U.S. 340 (1916) (Van Devanter joins McReynolds' opinion upholding Michigan statute regulating employment agencies).

${ }^{67}$ Compare Jay Burns Baking Co. v. Bryan, 264 U.S. 504 (1924) (Van Devanter, McReynolds, and Sutherland join Butler's opinion striking down Nebraska statute) with Petersen Baking Co. v. Bryan, 290 U.S. 570 (1934) (Van Devanter, McReynolds, and Sutherland join Butler's opinion upholding revised Nebraska statute) and Schmidinger v. City of Chicago, 226 U.S. 578 (1913) (Van Devanter joins opinion upholding Chicago ordinance).

* See, e.g., United States v. Miller, 307 U.S. 174 (1939) (Butler joins McReynolds' opinion upholding National Firearms Act); United States v. Maher, 307 U.S. 148 (1939) (applying Motor Carriers Act in preventing bus driver from transporting per- 
sons, with Butler and McReynolds joining opinion); Rochester Tel. Corp. v. United States, 307 U.S. 125 (1939) (placing telephone company within regulation of FCC) (McReynolds concurring in the result and joining Butler's concurring opinion); Hines v. Lowrey, 305 U.S. 85 (1938) (recognizing federal law limiting attorney's fees in veterans benefits suits, with Butler and McReynolds joining opinion); Swayne \& Hoyt Ltd. v. United States, 300 U.S. 297 (1937) (recognizing ability of Secretary of Commerce to set tariff rates, with Butler, McReynolds, and Van Devanter joining opinion) (Sutherland dissents); Cummings v. Deutsche Bank, 300 U.S. 115 (1937) (recognizing broad power in Congress to seize enemy property, with McReynolds, Sutherland, and Van Devanter joining Butler's opinion); Kuehner v. Irving Trust Co., 299 U.S. 445 (1937) (upholding provisions of Bankruptcy Act, with all Four Horsemen joining opinion); Kentucky Whip \& Collar Co. v. Illinois Cent. R.R., 299 U.S. 334 (1937) (all Four Horsemen join opinion upholding Ashurst-Sumners Act forbidding shipment of convict-made goods into states prohibiting their use, sale or possession); American Tel. \& Tel. v. United States, 299 U.S. 232 (1936) (upholding FCC regulations, with all Four Horsemen joining opinion); St. Joseph Stock Yards Co. v. United States, 298 U.S. 38 (1936) (upholding rate-fixing order of the Secretary of Agriculture, with all Four Horsemen joining opinion); United States v. Oregon, 295 U.S. 1 (1935) (upholding executive order creating a bird reservation, with all Four Horsemen joining opinion); Federal Radio Comm'n v. Nelson Bros. Bond \& Mtg. Co. 289 U.S. 266 (1933) (upholding the power of Congress under the Commerce Clause to regulate radio communications and the authority of Congress to delegate to the FRC the discretion to allocate the various broadcast channels as it deems necessary for the public interest, with all Four Horsemen joining opinion); Continental Ill. Nat'l Bank \& Trust Co. of Chi. v. Chicago R.I. \& Pac. Ry., 294 U.S. 648 (1935) (holding that injunctions issued pursuant to the Bankruptcy Act and preventing sales of collateral did not violate due process, with Butler, McReynolds, and Van Devanter joining Sutherland's opinion); Norwegian Nitrogen Prods. Co. v. United States, 288 U.S. 294 (1933) (giving executive agency broad discretion in setting tariff rates, with Butler, Sutherland, and Van Devanter joining opinion) (McReynolds dissents); Reichelderfer v. Quinn, 287 U.S. 315 (1932) (holding that Congress has power to modify housing contracts in D.C., with all Four Horsemen joining opinion); Highland v. Russell Car \& Snow Plow Co., 279 U.S. 253 (1929) (expansively reading congressional war powers, with McReynolds, Sutherland, and Van Devanter joining Butler's opinion); Hampton \& Co. v. United States, 276 U.S. 394 (1928) (upholding presidential delegation to Tariff Commission of investigative powers, with all Four Horsemen joining opinion); Atwater \& Co. v. United States, 275 U.S. 188 (1927) (ruling that government does not have to compensate for delays in crediting money owed under federal law, with McReynolds, Sutherland, and Van Devanter joining Butler's opinion); United States v. Alford, 274 U.S. 264 (1927) (ruling that Congress can prevent acts on private lands that endanger public lands, with all Four Horsemen joining opinion); Westfall v. United States, 274 U.S. 256 (1927) (broadly reading congressional power under the Federal Reserve Act, with all Four Horsemen joining opinion); Great N. Ry. v. Sutherland, 273 U.S. 182 (1927) (upholding forced transfer of enemy owned stocks, with Butler, McReynolds, and Van Devanter joining opinion) (Sutherland dissents); United States v. Chemical Found., Inc., 272 U.S. 1 (1926) (reiterating Congress's broad power to seize enemy property, with McReynolds and Van Devanter joining Butler's opinion) (Sutherland takes no part); Thornton v. United States, 271 U.S. 414 (1926) (broadly reading the power of the Department of Agriculture, with all Four Horsemen joining opinion); Littlejohn \& Co. v. United States, 270 U.S. 215 
(1926) (expansively reading the power of the government to seize enemy property, with Butler, Sutherland, and Van Devanter joining McReynolds' opinion); Goldsmith v. Board of Tax Appeals, 270 U.S. 117 (1926) (upholding board's power to set rules for admission of lawyers and accountants before it, with all Four Horsemen joining opinion); White v. Mechanics Sec. Corp., 269 U.S. 283 (1925) (recognizing government's power to seize enemy property, with all Four Horsemen joining opinion); Margolin v. United States, 269 U.S. 93 (1925) (upholding act limiting attorney's fees, with Butler, Sutherland, and Van Devanter joining McReynolds' opinion); Old Dominion Land Co. v. United States, 269 U.S. 55 (1925) (interpreting act to grant U.S. greater use of condemnation power, with all Four Horsemen joining opinion); Selzman v. United States, 268 U.S. 466 (1925) (broadly construing Congress's power to legislate under the Eighteenth Amendment, with all Four Horsemen joining opinion); Brooks v. United States, 267 U.S. 432 (1925) (all Four Horsemen join opinion upholding National Motor Vehicle Theft Act of 1919); United States v. ButterworthJudson Corp., 267 U.S. 387 (1925) (allowing government broad discretion over use of monetary advances granted to contractors to buy war supplies, with McReynolds, Sutherland, and Van Devanter joining Butler's opinion); Swiss Nat'l Ins. Co. v. Miller, 267 U.S. 42 (1925) (broadly construing the Trading with the Enemy Act, with Butler, Sutherland, and Van Devanter joining opinion) (McReynolds dissents); Erie Coal \& Coke Corp. v. United States, 266 U.S. 518 (1925) (holding that government has broad power to refuse certain contracts in the auctioning of public property, with McReynolds, Sutherland, and Van Devanter joining Butler's opinion); Campbell v. United States, 266 U.S. 368 (1924) (holding that the government need not compensate owners of property for diminution in value caused by public use takings, with McReynolds, Sutherland, and Van Devanter joining Butler's opinion); James Everard's Breweries v. Day, 265 U.S. 545 (1924) (expansively reading Congress' power to regulate under the Eighteenth Amendment, with all Four Horsemen joining opinion); Burnes Nat'l Bank v. Duncan, 265 U.S. 17 (1924) (upholding congressional regulation of national banks, with Butler and Van Devanter joining opinion) (McReynolds joins Sutherland's dissenting opinion); McConaughey v. Morrow, 263 U.S. 39 (1923) (expansively reading presidential power over Canal Zone, with all Four Horsemen joining opinion); United States v. Sischo, 262 U.S. 165 (1923) (upholding act requiring forfeiture of property contained on ship but not listed on ship's manifest, with all Four Horsemen joining opinion); Cunard S.S. Co. v. Mellon, 262 U.S. 100 (1923) (broadly construing Congress' power under the Eighteenth Amendment, with Butler joining Van Devanter's opinion) (McReynolds and Sutherland dissent); Commercial Trust Co. v. Miller, 262 U.S. 51 (1923) (upholding property seizure under the Trading with the Enemy Act, with all Four Horsemen joining opinion); Albert Hanson Lumber Co. v. United States, 261 U.S. 581 (1923) (allowing federal government to condemn certain land for the public good, with McReynolds, Sutherland, and Van Devanter joining Butler's opinion); Mason v. United States, 260 U.S. 545 (1923) (ruling that executive branch has power to declare certain lands off limits from settlement and appropriation, with Butler, McReynolds, and Van Devanter joining Sutherland's opinion); Morrisdale Coal Co. v. United States, 259 U.S. 188 (1922) (holding price fixing during war not a taking of property by government, with McReynolds and Van Devanter joining opinion); Grogan v. Hiram Walker \& Sons, 259 U.S. 80 (1922) (ruling that Eighteenth Amendment supersedes foreign treaties, with McReynolds and Van Devanter joining opinion); Leach v. Carlile, 258 U.S. 138 (1922) (holding that whether a product's labeling was misleading was solely within review of Postmaster General, with McReynolds and Van Devanter joining opinion); 
Economy Light \& Power Co. v. United States, 256 U.S. 113 (1921) (holding that Congress has power to regulate a non-navigable river, with Van Devanter joining opinion) (McReynolds takes no part); Stoehr v. Wallace, 255 U.S. 239 (1921) (upholding seizure of property under Trading with the Enemy Act, with McReynolds joining Van Devanter's opinion); Goldsmith Grant Co. v. United States, 254 U.S. 505 (1921) (upholding government power to confiscate goods which were hidden to avoid taxation, with Van Devanter joining opinion) (McReynolds dissents); National Prohibition Cases, 253 U.S. 350 (1920) (Van Devanter writes opinion upholding validity of the Eighteenth Amendment) (McReynolds concurs); United States v. Simpson, 252 U.S. 465 (1920) (upholding conviction for transporting liquor in violation of Reed Amendment, with McReynolds joining Van Devanter's opinion); Cameron v. United States, 252 U.S. 450 (1920) (upholding authority of President to set aside land for forest reserves, with McReynolds joining Van Devanter's opinion); Missouri v. Holland, 252 U.S. 416 (1920) (upholding treaty giving federal government the power to regulate the hunting of migratory birds, with McReynolds joining opinion) (Van Devanter dissents); Kansas City S. Ry. v. United States, 252 U.S. 147 (1920) (upholding federal fines against railway for delay in delivering mail, with McReynolds and Van Devanter joining opinion); Grand T.W. Ry. v. United States, 252 U.S. 112 (1920) (forcing railroad to transport mail because railroad's land was granted by the federal government on the condition of carrying the mails, with McReynolds and Van Devanter joining opinion); Public Util. Comm'rs v. Ynchausti \& Co., 251 U.S. 401 (1920) (upholding power of Congress to force carrier to ship mail for free, with McReynolds and Van Devanter joining opinion); Northern Pac. Ry. v. North Dakota, 250 U.S. 135 (1919) (holding that federal war powers supersede rights of state governments to set intrastate rail rates, with McReynolds and Van Devanter joining opinion); Houston v. St. Louis lndep. Packing Co., 249 U.S. 479 (1919) (upholding product label regulation by Secretary of Agriculture, with McReynolds and Van Devanter joining opinion); Missouri Pac. Ry. v. Kansas, 248 U.S. 276 (1919) (upholding Webb-Kenyon Act, with McReynolds and Van Devanter joining opinion); Ruddy v. Rossi, 248 U.S. 104 (1918) (upholding power of Congress to limit the alienation of land granted under the Homestead Act, with Van Devanter joining McReynolds' opinion); Pittsburgh Melting Co. v. Totten, 248 U.S. 1 (1918) (upholding regulation of food products by Department of Agriculture, with McReynolds and Van Devanter joining opinion); First Nat'l Bank v. Fellows ex rel. Union Trust Co., 244 U.S. 416 (1917) (upholding part of Federal Reserve Bank Act, with McReynolds joining opinion) (Van Devanter dissents); Chicago, M. \& St. P. Ry. v. United States, 244 U.S. 351 (1917) (upholding award for government for trees cut while building railroad through national forest, with Van Devanter writing opinion) (McReynolds takes no part); Chesbrough v. Woodworth, 244 U.S. 72 (1917) (upholding award for investor under National Bank Act, with McReynolds and Van Devanter joining opinion); Oregon \& Cal. R.R. v. United States, 243 U.S. 549 (1917) (enjoining railroads from selling lands granted to them from federal government, with Van Devanter joining opinion) (McReynolds takes no part); Utah Power \& Light Co. v. United States, 243 U.S. 389 (1917) (holding federal title to land superior to state, with McReynolds joining Van Devanter's opinion); Louisville Bridge Co. v. United States, 242 U.S. 409 (1917) (forcing bridge company to rebuild bridge according to specifications of Secretary of War, with McReynolds and Van Devanter joining opinion); Lane v. United States ex rel. Mickadiet, 241 U.S. 201 (1916) (holding Secretary of Interior has sole power to determine heirs of Indian man, with Van Devanter joining opinion) (McReynolds takes no part); Town of Essex v. New England Tel. Co., 239 U.S. 313 (1916) (upholding 
power of Congress to allow telegraph lines to be built over postal routes, with Van Devanter joining McReynolds' opinion); Delaware, L. \& W.R.R. v. United States, 231 U.S. 363 (1913) (upholding application of commodities clause of Hepburn Act against Fifth Amendment challenge, with Van Devanter joining opinion); McDermott v. Wisconsin, 228 U.S. 115 (1913) (noting that Congress has power to bar from commerce harmful or illicit articles, with Van Devanter joining opinion); United States v. Grimaud, 220 U.S. 506 (1911) (approving congressional delegation of regulatory power to the Secretary of Agriculture by upholding regulation requiring permit to graze any livestock or forest reserve, with Van Devanter joining opinion); Light v. United States, 220 U.S. 523 (1911) (same); Baltimore \& O.S.W.R.R. v. United States, 220 U.S. 94 (1911) (extending act to prevent the cruelty of animals to all interstate shipments of cattle, with Van Devanter joining opinion).

${ }^{69}$ See United States v. 95 Barrels of Vinegar, 265 U.S. 438 (1924) (Van Devanter, McReynolds, and Sutherland join Butler's opinion reading broadly the Act's prohibition against misbranding so as to prevent the use of misleading as well as false labels); United States v. Schider, 246 U.S. 519 (1918) (Van Devanter joins McReynolds' opinion reversing judgment sustaining demurrer to indictment for violating Act's misbranding prohibition); Weeks v. United States, 245 U.S. 618 (1918) (McReynolds joins Van Devanter's opinion affirming conviction for violation of Act's misbranding prohibition); United States v. Coca Cola Co., 241 U.S. 265 (1916) (Van Devanter joins opinion overturning directed verdict for company charged with misbranding) (McReynolds takes no part); Seven Cases of Eckman's Alternative v. United States, 239 U.S. 510 (1916) (Van Devanter joins opinion upholding Sherley Amendment to Act, defining misbranding to include false and fraudulent claims of curative effects) (McReynolds takes no part); United States v. Antikamnia Chem. Co., 231 U.S. 654 (1914) (Van Devanter joins opinion upholding regulations promulgated to enforce the Act); Hipolite Egg Co. v. United States, 220 U.S. 45 (1911) (Van Devanter joins opinion upholding application of the Act to articles within the borders of a state); see also United States v. Lewis, 235 U.S. 282 (1914) (Van Devanter joins opinion reversing judgment quashing indictment under Meat Inspection Law of 1906) (McReynolds takes no part).

${ }^{n}$ Second Employers' Liability Cases, 223 U.S. 1 (1912) (Van Devanter writes opinion upholding the Act).

${ }^{n}$ See United States v. California, 297 U.S. 175 (1936) (all Four Horsemen join opinion holding that state-owned railroads were subject to the Act); New York Cent. R.R. v. United States, 265 U.S. 41 (1924) (Van Devanter, McReynolds, and Sutherland join Butler's opinion reading expansively the duty imposed by the Act on the railroads to have their cars equipped with power brakes for the safety of their employees); United States v. Northern Pac. Ry., 254 U.S. 251 (1920) (Van Devanter and McReynolds join opinion rejecting claim that Act does not apply to "transfer trains" operating within rail yard and not on main track); Spokane \& I. Emp. R.R. v. United States, 241 U.S. 344 (1916) (Van Devanter joins opinion holding that street railway cars employed in interstate traffic were subject to the Act) (McReynolds takes no part); Southern Ry. v. United States, 222 U.S. 20 (1911) (Van Devanter writes opinion upholding the Act).

${ }^{n}$ See United States v. Corrick, 298 U.S. 435 (1936) (all Four Horsemen join opinion reversing order enjoining Secretary of Agriculture from instituting prosecutions for violations of an order fixing rates under the Act); Acker v. United States, 298 U.S. 426 (1936) (all Four Horsemen join opinion upholding rates established by the Secretary of Agriculture under the Act); Tagg Bros. \& Moorhead v. United States, 
280 U.S. 420 (1930) (all Four Horsemen join opinion sustaining Act against due process challenge); United States v. American Livestock Comm'n Co., 279 U.S. 435 (1929) (all Four Horsemen join opinion recognizing power of Secretary of Agriculture under the Act to order discontinuance of boycott of market agency by others on livestock exchange); Stafford v. Wallace, 258 U.S. 495 (1922) (Van Devanter joins opinion sustaining Act against Commerce Clause challenge) (McReynolds dissents).

${ }^{73}$ See Chicago Bd. of Trade v. Olsen, 262 U.S. 1 (1923) (Van Devanter and Butler join opinion upholding Grain Futures Act) (McReynolds and Sutherland dissent).

${ }^{74}$ See, e.g., United States v. Summerlin, 310 U.S. 414 (1940) (McReynolds joins opinion reversing lower court decision that state statute of limitations bars FHA's claim against decedent's estate); Pittman v. Home Owners' Loan Corp., 308 U.S. 21 (1939) (McReynolds joins opinion affirming order requiring local court clerk to record mortgage held by Home Owners' Loan Corp. without payment of the usual recording fees) (Butler takes no part); United States v. Powers, 307 U.S. 214 (1939) (McReynolds and Butler join opinion reversing lower court decision sustaining demurrers to an indictment under the Connally Hot Oil Act); Utah Fuel Co. v. National Bituminous Coal Comm'n, 306 U.S. 56 (1939) (Butler joins McReynolds opinion sustaining authority of commission to disclose business data furnished by coal producers pursuant to commission's order); Electric Bond \& Share Co. v. SEC, 303 U.S. 419 (1938) (Butler joins opinion upholding provision of Public Utility Act of 1935 requiring public utility holding companies to register with the SEC) (McReynolds dissents); Wright v. Vinton Branch, 300 U.S. 440 (1937) (upholding revised FrazierLemke Act, with all Four Horsemen joining opinion); Ashwander v. Tennessee Valley Auth., 297 U.S. 288 (1936) (Van Devanter, Sutherland, and Butler join opinion upholding power of Congress to authorize construction of a vast hydroelectric dam project and the sale of the electricity produced there in competition with private power companies) (McReynolds dissents). See also note 52, supra, and cases cited therein.

${ }^{75}$ See, e.g., United States v. Chicago Heights Trucking Co., 310 U.S. 344 (1940) (reversing lower court decree enjoining ICC order, with McReynolds joining opinion); United States v. Lowden, 308 U.S. 225 (1939) (reversing lower court decree enjoining ICC order, with McReynolds joining opinion); Union Stock Yard \& Transit Co. v. United States, 308 U.S. 213 (1939) (affirming dismissal of petition seeking to set aside ICC order nullifying rate update made by rail company, with McReynolds joining opinion); Valvoline Oil Co. v. United States, 308 U.S. 141 (1939) (affirming dismissal of petition seeking to enjoin ICC order, with McReynolds joining opinion) (Butler takes no part); Baldwin v. Scott County Milling Co., 307 U.S. 478 (1939) (upholding power of ICC to reverse and amend its own orders, with McReynolds joining Butler's opinion); Lowden v. Simonds-Shields-Lonsdale Grain Co., 306 U.S. 516 (1939) (affirming tariff set by ICC on producers of grain, with Butler and McReynolds joining opinion); United States v. Pan Am. Petroleum Corp., 304 U.S. 156 (1938) (reversing decree for company seeking to enjoin ICC order, with Butler and McReynolds joining opinion); Baltimore \& O.R.R. v. United States, 304 U.S. 58 (1938) (upholding dismissal of case seeking to enjoin enforcement of ICC order, with Butler joining McReynolds' opinion); United States v. American Sheet \& Tin Plate Co., 301 U.S. 402 (1937) (reversing lower court ruling setting aside ICC order requiring carriers to desist from spotting cars on industrial plant tracks, with McReynolds, Sutherland, and Van Devanter joining opinion) (Butler dissents); United States v. Idaho, 298 U.S. 105 (1936) (upholding ICC order allowing abandonment of a railroad spur track, with all Four Horsemen joining opinion); Pennsylvania R.R. v. 
Illinois Brick Co., 297 U.S. 447 (1936) (upholding ICC decree ordering intrastate rate increase to end discrimination against interstate commerce, with McReynolds, Sutherland, and Van Devanter joining Butler's opinion); Atlanta, B. \& C.R.R. v. United States, 296 U.S. 33 (1935) (refusing to question factual determination of ICC concerning accounting and valuation practices, with all Four Horsemen joining opinion); Youngstown Sheet \& Tube Co. v. United States, 295 U.S. 476 (1935) (upholding rate structure set by ICC, with all Four Horsemen joining opinion); United States v. Baltimore \& O.R.R., 293 U.S. 454 (1935) (upholding power of ICC to require railroads to change safety equipment, with all Four Horsemen joining opinion); Ohio v. United States, 292 U.S. 498 (1934) (upholding ICC order raising intrastate coal rates to end interstate discrimination, with all Four Horsemen joining opinion); Illinois Commerce Comm'n v. United States, 292 U.S. 474 (1934) (upholding factual determination of ICC in rate raising order, with all Four Horsemen joining opinion); Mississippi Valley Barge Line Co. v. United States, 292 U.S. 282 (1934) (stating that ICC order will be upheld so long as some rational basis exists for its determination and upholding decision of ICC to lower rates, with all Four Horsemen joining opinion); Florida v. United States, 292 U.S. 1 (1934) (upholding power of ICC to increase intrastate rates, with all Four Horsemen joining opinion); United States v. Illinois Cent. R.R., 291 U.S. 457 (1934) (holding that challenger to ICC order must exhaust remedies of ICC before appealing to courts, with Butler, McReynolds, and Van Devanter joining Sutherland's opinion); United States v. Louisiana, 290 U.S. 70 (1933) (upholding ICC's power to prescribe minimum intrastate rates, with all Four Horsemen joining opinion); United States v. Northern Pac. Ry., 288 U.S. 490 (1933) (limiting rehearing to challenge order of ICC, with all Four Horsemen joining opinion); Norfolk \& W. Ry. v. United States, 287 U.S. 134 (1932) (allowing ICC broad discretion in requiring certain accounting practices, with McReynolds, Sutherland, and Van Devanter joining opinion) (Butler takes no part); Adams v. Mills, 286 U.S. 397 (1932) (upholding factual findings of ICC as conclusive, with McReynolds, Sutherland, and Van Devanter joining opinion) (Butler dissents on standing grounds); Claiborne-Annapolis Ferry Co. v. United States, 285 U.S. 382 (1932) (upholding ICC permit allowing extension of railroad line, with Butler, Sutherland, and Van Devanter joining McReynolds' opinion); Transit Comm'n v. United States, 284 U.S. 360 (1932) (upholding ICC order forcing railroad to abandon an unprofitable line, with all Four Horsemen joining opinion); Atlantic Coast L.R.R. v. United States, 284 U.S. 288 (1932) (upholding power of ICC to place conditions on leases by railroads, with all Four Horsemen joining opinion); Louisiana Pub. Serv. Comm'n v. Texas \& N.O.R.R., 284 U.S. 125 (1931) (upholding ICC order raising interstate rates, with McReynolds, Sutherland, and Van Devanter joining Butler's opinion); Georgia Pub. Serv. Comm'n v. United States, 283 U.S. 765 (1931) (recognizing the power of ICC to set intrastate rates, with all Four Horsemen joining opinion); Lewis-Simas-Jones Co. v. Southern Pac. Co., 283 U.S. 654 (1931) (upholding power of ICC to attack international through rates it deems excessive, with McReynolds, Sutherland, and Van Devanter joining Butler's opinion); Merchants Warehouse Co. v. United States, 283 U.S. 501 (1931) (upholding ICC's factual conclusions of discrimination in warehouse leasing, with all Four Horsemen joining opinion); Standard Oil Co. v. United States, 283 U.S. 235 (1931) (limiting court's jurisdiction to overturn certain negative orders of ICC, with Butler, McReynolds, and Van Devanter joining Sutherland's opinion); Louisville \& Nash. R.R. v. United States, 282 U.S. 740 (1931) (upholding order of ICC prohibiting transport of certain rail cars at reduced rates, with Butler and Van Devanter joining opinion) (McReynolds and Sutherland dissent); Pittsburgh \& W. Va. 
Ry. v. United States, 281 U.S. 479 (1930) (limiting power of one railroad to sue to change a rate set by the ICC for a competitor, with all Four Horsemen joining opinion); Alexander Sprunt \& Son v. United States, 281 U.S. 249 (1930) (limiting standing rights of certain shippers disadvantaged by ICC order, with all Four Horsemen joining opinion); United States v. Erie R.R., 280 U.S. 98 (1929) (upholding power of ICC to set intrastate rates involving foreign commerce, with all Four Horsemen joining opinion); Atchison, T. \& S.F. Ry. v. United States, 279 U.S. 768 (1929) (liberally construing the power of the ICC to determine the reasonableness of rates, with all Four Horsemen joining opinion); Alabama v. United States, 279 U.S. 229 (1929) (upholding power of ICC to set intrastate rates, with Butler, McReynolds, and Van Devanter joining Sutherland's opinion); Great N. Ry. v. United States, 277 U.S. 172 (1928) (limiting the power of companies to have an ICC order reviewed, with all Four Horsemen joining opinion); Cleveland, C., Chi. \& S. Ry. v. United States, 275 U.S. 404 (1928) (extending the power of ICC to require railroads to build switch connections, with all Four Horsemen joining opinion); News Synd. Co. v. New York Cent. R.R., 275 U.S. 179 (1927) (upholding power of ICC to determine reasonableness of international through rates, with McReynolds, Sutherland, and Van Devanter joining Butler's opinion); The Assigned Car Cases, 274 U.S. 564 (1927) (upholding ICC regulation limiting the number of cars among coal mines, with Butler, Sutherland, and Van Devanter joining opinion) (McReynolds dissents); Chicago, R.I. \& Pac. Ry. v. United States, 274 U.S. 29 (1927) (deferring to ICC's factual determination, with Butler, McReynolds, and Van Devanter joining Sutherland's opinion); United States v. Los Angeles \& S.L.R.R., 273 U.S. 299 (1927) (upholding statutory provision making all property valuations by ICC prima facie evidence in court actions, with McReynolds, Sutherland, and Van Devanter joining opinion) (Butler takes no part); Virginian Ry. v. United States, 272 U.S. 658 (1926) (allowing ICC wide latitude in determining unjustness of rates, with all Four Horsemen joining opinion); United States v. New York Cent. R.R., 272 U.S. 457 (1926) (expansively reading power of ICC to force a carrier to provide transportation services, with Butler, McReynolds, and Van Devanter joining opinion) (Sutherland takes no part); Western Paper Makers' Chem. Co. v. United States, 271 U.S. 268 (1926) (limiting procedural requirements in ICC hearings, with all Four Horsemen joining opinion); Turner, Dennis \& Lowry Lumber Co. v. Chicago, M. \& S. Ry., 271 U.S. 259 (1926) (upholding power of ICC to place charges on certain cargoes, with all Four Horsemen joining opinion); Colorado v. United States, 271 U.S. 153 (1926) (expansively reading power of ICC to authorize abandonment of railroad branch lines, with all Four Horsemen joining opinion); Venner v. Michigan Cent. R.R., 271 U.S. 127 (1926) (limiting the ability of shareholder to prevent company from complying with ICC order, with Butler, McReynolds, and Sutherland joining Van Devanter's opinion); United States v. P. Koenig Coal Co., 270 U.S. 512 (1926) (construing a criminal statute against contracting around ICC rate schedules in favor of ICC, with all Four Horsemen joining opinion); Chicago, I. \& L. Ry. v. United States, 270 U.S. 287 (1926) (upholding power of the ICC to structure contractual agreements between carriers, with all Four Horsemen joining opinion); Louisville \& Nash. R.R. v. Sloss-Sheffield Steel \& Iron Co., 269 U.S. 217 (1925) (upholding an ICC order requiring carrier to make a reparation of the excess charged over established freight rate, with Butler, Sutherland, and Van Devanter joining opinion) (McReynolds writes separately arguing defendant suffered no damage); United States v. Village of Hubbard, 266 U.S. 474 (1925) (upholding power of ICC to increase intrastate interurban railway rates, with Butler, Sutherland, and Van Devanter joining opinion) (McReynolds writes separately); 
United States v. Pennsylvania R.R., 266 U.S. 191 (1924) (broadly construing ICC's power to end discrimination in carrier service, with all Four Horsemen joining opinion); United States v. New River Co., 265 U.S. 533 (1924) (ruling ICC has power to regulate the distribution of coal cars, with McReynolds, Sutherland, and Van Devanter joining Butler's opinion); Dayton-Goose Creek Ry. v. United States, 263 U.S. 456 (1924) (allowing ICC great leeway in setting rates, with all Four Horsemen joining opinion); Nashville, C. \& St. L. Ry. v. Tennessee, 262 U.S. 318 (1923) (allowing ICC to set aside state regulations of intrastate rates if they unduly affect interstate commerce, with all Four Horsemen joining opinion); New England Divisions Case, 261 U.S. 184 (1923) (expansively reading the ICC's power to set rates, with all Four Horsemen joining opinion); Keogh v. Chicago \& N.W. Ry., 260 U.S. 156 (1922) (affirming ICC's power to set binding rates on shippers, with all Four Horsemen joining opinion); Texas v. ICC, 258 U.S. 158 (1922) (dismissing bill by state to enjoin ICC order, with McReynolds joining Van Devanter's opinion); New York v. United States, 257 U.S. 591 (1922) (affirming dismissal of a bill by state to enjoin enforcement of ICC order, with McReynolds and Van Devanter joining opinion); Louisiana \& P.B. Ry. v. United States, 257 U.S. 114 (1921) (upholding rate on tap lines set by ICC, with McReynolds and Van Devanter joining opinion); Pennsylvania R.R. v. Weber, 257 U.S. 85 (1921) (upholding ICC reparation award to shipper, with McReynolds and Van Devanter joining opinion); Seaboard Air Line Ry. v. United States, 254 U.S. 57 (1920) (upholding ICC order preventing railroads from absorbing switching charges, with McReynolds and Van Devanter joining opinion); Spiller v. Atchison, T. \& S.F. Ry., 253 U.S. 117 (1920) (reversing lower court ruling invalidating ICC reparation order, with Van Devanter and McReynolds joining opinion); Southern Pac. Co. v. Darnell-Taenzer Lumber Co., 245 U.S. 531 (1918) (upholding reparation award granted by ICC, with McReynolds and Van Devanter joining opinion); Louisville \& Nash. R.R. v. United States, 245 U.S. 463 (1918) (affirming order of ICC restricting rate levels on certain rail routes, with McReynolds and Van Devanter joining opinion); St. Louis S.W. Ry. v. United States, 245 U.S. 136 (1917) (dismissing bill seeking enjoinment of ICC rate setting order, with McReynolds and Van Devanter joining opinion); Smith v. ICC, 245 U.S. 33 (1917) (requiring company leaders to disclose political expenditures to the ICC, with McReynolds and Van Devanter joining opinion); American Express Co. v. South Dakota ex rel. Caldwell, 244 U.S. 617 (1917) (holding that state cannot regulate rates affected by ICC order, with McReynolds and Van Devanter joining opinion); United States v. Illinois Cent. R.R., 244 U.S. 82 (1917) (reversing lower court ruling setting aside ICC order, with McReynolds and Van Devanter joining opinion); Lehigh Valley R.R. v. United States, 243 U.S. 444 (1917) (upholding injunction granted to ICC preventing railroad from charging less than published rates, with McReynolds and Van Devanter joining opinion); Lehigh Valley R.R. v. United States, 243 U.S. 412 (1917) (affirming dismissal of action to enjoin enforcement of ICC order, with McReynolds and Van Devanter joining opinion); United States v. Merchants \& Mfrs. Traffic Ass'n of Sacramento, 242 U.S. 178 (1916) (reversing lower court decision enjoining enforcement of ICC rate setting order, with Van Devanter and McReynolds joining opinion); $O^{\prime}$ Keefe v. United States, 240 U.S. 294 (1916) (affirming dismissal of suit to enjoin enforcement of ICC order, with Van Devanter joining opinion) (McReynolds takes no part); Mills v. Lehigh Valley R.R., 238 U.S. 473 (1915) (affirming ruling of ICC granting reparations for discriminatory rates, with McReynolds and Van Devanter joining opinion); Louisville \& Nash. R.R. v. United States, 238 U.S. 1 (1915) (affirming order of ICC reducing freight costs for coal, with Van Devanter joining 
opinion) (McReynolds takes no part); Pennsylvania Co. v. United States, 236 U.S. 351 (1915) (holding that ICC has the power to force certain carriers to ship freight from connecting carriers, with Van Devanter joining opinion) (McReynolds takes no part); Intermountain Rate Cases, 234 U.S. 476 (1914) (upholding ICC order concerning railroad rates for long hauls, with Van Devanter joining opinion); Houston, E. \& W. Tex. Ry. v. United States, 234 U.S. 342 (1914) (holding that ICC has power to regulate intrastate rates, with Van Devanter joining opinion); ICC v. Southern Pac. Co., 234 U.S. 315 (1914) (upholding ICC order preventing railroads from charging certain switching charges on spur lines, with Van Devanter joining opinion); Los Angeles Switching Case, 234 U.S. 294 (1914) (upholding ICC order preventing railroads from imposing switching charges, with Van Devanter joining opinion); The Tap Line Cases, 234 U.S. 1 (1914) (upholding ICC order requiring trunk line railroads to desist from making allowances to tap line owners, with McReynolds and Van Devanter joining opinion); Atchison, T. \& S.F. Ry. v. United States, 232 U.S. 199 (1914) (deferring to rate setting power of the ICC, with Van Devanter joining opinion); Kansas City S. Ry. v. United States, 231 U.S. 423 (1913) (reaffirming constitutionality of ICC's authority to prescribe accounting methods, with Van Devanter joining opinion); United States v. Adams Express Co., 229 U.S. 381 (1913) (upholding ICC's power to regulate express companies, with Van Devanter joining opinion); ICC v. Louisville \& Nash. R.R., 227 U.S. 88 (1913) (upholding ICC order lowering connecting rates, with Van Devanter joining opinion); United States v. Union Stock Yard \& Transit Co., 226 U.S. 286 (1912) (holding that certain companies were within jurisdiction of ICC, with Van Devanter joining opinion); ICC v. United States, 224 U.S. 474 (1912) (holding that the Hepburn Act extends ICC's authority to Alaska, with Van Devanter joining opinion); ICC v. Goodrich Transit Co., 224 U.S. 194 (1912) (upholding Interstate Commerce Act provisions requiring carriers to conduct accounting in the manner prescribed by the ICC, with Van Devanter joining opinion); ICC v. Union Pac. R.R., 222 U.S. 541 (1912) (upholding ICC order despite evidentiary concerns of railroad, with Van Devanter joining opinion); ICC v. Delaware, L. \& W.R.R., 220 U.S. 235 (1911) (upholding ICC order forbidding enforcement of a carrier rule prohibiting the aggregation of shipments of various owners for the purpose of carload classification, with Van Devanter joining opinion).

${ }^{76}$ See, e.g., FTC v. Standard Educ. Soc'y, 302 U.S. 112 (1937) (McReynolds, Sutherland, and Butler join opinion upholding FTC cease and desist order); FTC v. Keppel \& Bros., 291 U.S. 304 (1934) (all Four Horsemen join opinion upholding FTC cease and desist order); FTC v. Algoma Lumber Co., 291 U.S. 67 (1934) (all Four Horsemen join opinion upholding FTC cease and desist order); FTC v. Royal Milling Co., 288 U.S. 212 (1933) (Van Devanter and Butler join Sutherland opinion upholding FTC cease and desist order); FTC v. Pacific States Paper Trade Ass'n, 273 U.S. 52 (1927) (Van Devanter, McReynolds, and Sutherland join Butler's opinion upholding FTC cease and desist order in price fixing case); FTC v. Winsted Hosiery Co., 258 U.S. 483 (1922) (Van Devanter joins opinion upholding FTC cease and desist order); FTC v. Beech-Nut Packing Co., 257 U.S. 441 (1922) (Van Devanter joins opinion upholding FTC cease and desist order) (McReynolds dissents).

${ }^{7}$ See, e.g., C.E. Stevens Co. v. Foster \& Kleiser Co., 311 U.S. 255 (1940) (McReynolds joins opinion reversing dismissal of Sherman Act suit); Hill v. United States ex rel. Weiner, 300 U.S. 105 (1937) (Van Devanter, McReynolds, and Butler join Sutherland's opinion upholding punishment for contempt under Clayton Act); Indiana Farmer's Guide Publ'g Co. v. Prairie Farmer Publ'g Co., 293 U.S. 268 (1934) (Van Devanter, McReynolds, and Sutherland join Butler's opinion reversing directed 
verdict for antitrust defendant); Appalachian Coals, Inc. v. United States, 288 U.S. 344 (1933) (McReynolds dissents from opinion, in which Butler, Sutherland, and Van Devanter join, finding no Sherman Act violation); Atlantic Cleaners \& Dryers v. United States, 286 U.S. 427 (1932) (Van Devanter, McReynolds, and Butler join Sutherland's opinion finding Sherman Act violation); Story Parchment Co. v. Paterson Parchment Paper Co., 282 U.S. 555 (1931) (Van Devanter, McReynolds, and Butler join Sutherland's opinion affirming judgment for antitrust plaintiff); United States v. First Nat'l Pictures, Inc., 282 U.S. 44 (1930) (Van Devanter, Sutherland, and Butler join McReynolds' opinion finding Sherman Act violation); Paramount Famous Lasky Corp. v. United States, 282 U.S. 30 (1930) (Van Devanter, Sutherland, and Butler join McReynolds' opinion finding Sherman Act violation); George Van Camp \& Sons Co. v. American Can Co., 278 U.S. 245 (1929) (Van Devanter, McReynolds, and Butler join Sutherland's opinion finding Clayton Act violation); United States v. Goldman, 277 U.S. 229 (1928) (all Four Horsemen join opinion reversing dismissal of criminal contempt proceedings against defendants charged with violating an injunction enforcing the Sherman Act); Brown v. United States, 276 U.S. 134 (1928) (Van Devanter, McReynolds, and Butler join Sutherland's opinion upholding criminal contempt conviction of Sherman Act defendant who refused to comply with a subpoena duces tecum); United States v. Sisal Sales Corp., 274 U.S. 268 (1927) (Van Devanter, Sutherland, and Butler join McReynolds' opinion finding Sherman Act violation); United States v. Trenton Potteries Co., 273 U.S. 392 (1927) (McReynolds joins opinion upholding Sherman Act conviction) (Butler, Sutherland, and Van Devanter dissent); United States v. Brims, 272 U.S. 549 (1926) (Van Devanter, Sutherland, and Butler join McReynolds' opinion finding Sherman Act violation); United States v. American Linseed Oil Co., 262 U.S. 371 (1923) (Van Devanter, Sutherland, and Butler join McReynolds' opinion finding Sherman Act violation); Hart v. B.F. Keith Vaudeville Exch., 262 U.S. 271 (1923) (all Four Horsemen join opinion reversing dismissal of antitrust suit); Ramsay Co. v. Bill Posters Ass'n, 260 U.S. 501 (1923) (Van Devanter, Sutherland, and Butler join McReynolds' opinion finding Sherman Act violation); United Shoe Mach. Corp. v. United States, 258 U.S. 451 (1922) (Van Devanter and McReynolds join opinion finding Clayton Act violation); Standard Fashion Co. v. Magrane-Houston Co., 258 U.S. 346 (1922) (Van Devanter and McReynolds join opinion finding Clayton Act violation); American Column \& Lumber Co. v. United States, 257 U.S. 377 (1921) (Van Devanter and McReynolds join opinion affirming Sherman Act conviction); Sampliner v. Motion Picture Patents Co., 254 U.S. 233 (1920) (Van Devanter joins McReynolds' opinion reversing judgment directing verdict for Sherman Act defendant); United States v. A. Schrader's Son, Inc., 252 U.S. 85 (1920) (Van Devanter joins McReynolds' opinion reversing judgment sustaining demurrer to indictment for violation of the Sherman Act); Thomsen v. Cayser, 243 U.S. 66 (1917) (Van Devanter and McReynolds join opinion affirming judgment for Sherman Act plaintiff); Straus \& Straus v. American Publishers' Ass'n, 231 U.S. 222 (1913) (Van Devanter joins opinion reversing judgment for Sherman Act defendant); United States v. Pacific \& Ârc. Ry. \& Nav. Co., 228 U.S. 87 (1913) (Van Devanter joins opinion reversing judgment sustaining demurrer to Sherman Act indictment); Central Lumber Co. v. South Dakota, 226 U.S. 157 (1912) (Van Devanter joins opinion affirming state antitrust conviction); Standard Sanitary Mfg. Co. v. United States, 226 U.S. 20 (1912) (Van Devanter joins opinion finding Sherman Act violation); Dr. Miles Med. Co. v. John D. Park \& Sons, 220 U.S. 373 (1911) (Van Devanter joins opinion invalidating resale price maintenance scheme under Sherman Act). See also Carbice Corp. v. American Patents Dev. Corp., 283 U.S. 27 (1931) 
(holding that a patentee cannot require a licensee to purchase unpatented materials used in connection with the invention from patentee, with all Four Horsemen joining opinion); Straus v. Victor Talking Mach. Co., 243 U.S. 490 (1917) (McReynolds joins opinion invalidating attempt to use a patent to fix prices) (Van Devanter dissents); United States v. Munday, 222 U.S. 175 (1911) (upholding congressional legislation seeking to prevent monopolization of coal lands, with Van Devanter joining opinion).

${ }^{78}$ See, e.g., United States v. Southern Pac. Co., 259 U.S. 214 (1922) (Van Devanter joins opinion holding acquisition of one railroad by another violates Sherman Act) (McReynolds takes no part); Continental Ins. Co. v. United States, 259 U.S. 156 (1922) (Van Devanter and McReynolds join opinion affirming decree dissolving combination of railroad and coal companies pursuant to Sherman Act); United States v. Lehigh Valley R.R., 254 U.S. 255 (1920) (Van Devanter joins opinion dissolving combination of railroad and coal companies formed in violation of the Sherman Act) (McReynolds takes no part); United States v. Reading Co., 253 U.S. 26 (1920) (McReynolds joins opinion dissolving combination of railroad and coal companies formed in violation of the Sherman Act) (Van Devanter dissents); United States v. Delaware, L. \& W.R.R., 238 U.S. 516 (1915) (Van Devanter joins opinion enjoining coal transportation because of Sherman Act violation) (McReynolds takes no part); United States v. Reading Co., 226 U.S. 324 (1912) (Van Devanter joins opinion enjoining Sherman Act violation); United States v. Terminal R.R. Ass'n of St. L., 224 U.S. 383 (1912) (Van Devanter joins opinion enjoining Sherman Act violation).

${ }^{79}$ See, e.g., Sugar Inst. v. United States, 297 U.S. 553 (1936) (all Four Horsemen join opinion finding that activities of trade association violate the Sherman Act); Cement Mfrs. Protective Ass'n v. United States, 268 U.S. 588 (1925) (McReynolds dissents from opinion, in which Butler, Sutherland, and Van Devanter join, reversing order enjoining activities of trade association as violations of the Sherman Act); Maple Flooring Mfg. Ass'n v. United States, 268 U.S. 563 (1925) (McReynolds dissents from opinion, in which Butler, Sutherland, and Van Devanter join, reversing order enjoining activities of trade association as violations of the Sherman Act); Eastern States Retail Lumber Dealers' Ass'n v. United States, 234 U.S. 600 (1914) (Van Devanter joins opinion affirming order enjoining trade association from engaging in activities violative of the Sherman Act).

${ }^{80}$ See, e.g., United States v. Borden Co., 308 U.S. 188 (1939) (McReynolds joins opinion reversing dismissal of indictments for Sherman Act violations); Puerto Rico v. Shell Co., 302 U.S. 253 (1937) (McReynolds and Butler join Sutherland's opinion reversing dismissal of prosecution of Shell for violation of local antitrust law); Aluminum Co. v. United States, 302 U.S. 230 (1937) (Sutherland and Butler join McReynolds' opinion authorizing federal government to bring a second antitrust action against ALCOA notwithstanding an earlier consent decree entered in another district); International Bus. Mach. Corp. v. United States, 298 U.S. 131 (1936) (all Four Horsemen join opinion enjoining certain tying clauses as Clayton Act violation); Eastman Kodak Co. v. Southern Photo Materials Co., 273 U.S. 359 (1927) (all Four Horsemen join opinion affirming damage award judgment against Eastman Kodak for antitrust violation); International Harvester Co. v. Missouri, 234 U.S. 199 (1914) (Van Devanter joins opinion affirming judgment for the state in Missouri antitrust quo warranto proceeding); United States v. American Tobacco Co., 221 U.S. 106 (1911) (Van Devanter joins opinion dissolving unlawful combination); Standard Oil Co. of N.J. v. United States, 221 U.S. 1 (1911) (Van Devanter joins opinion dissolving unlawful combination). 
${ }^{81}$ See, e.g., Apex Hosiery Co. v. Leader, 310 U.S. 469 (1940) (McReynolds joins dissent from opinion overturning Sherman Act judgment against laborers engaged in a sit-down strike); Bedford Cut Stone Co. v. Journeymen Stone Cutters Ass'n, 274 U.S. 37 (1927) (Van Devanter, McReynolds, and Butler join Sutherland's opinion enjoining as a Sherman Act violation a stonecutter union's boycott of stone quarried by members of unaffiliated unions); Coronado Coal Co. v. United Mine Workers, 268 U.S. 295 (1925) (all Four Horsemen join opinion which, while exempting the international union from liability, holds that there was sufficient evidence of intent to restrain trade to allow the company's Sherman Act claim against the local union to go to the jury); American Steel Foundries v. Tri-City Cent. Trades Council, 257 U.S. 184 (1921) (Van Devanter and McReynolds join opinion placing limits on union's rights to picket); Duplex Printing Press Co. v. Deering, 254 U.S. 443 (1921) (Van Devanter and McReynolds join opinion enjoining union's secondary boycott as a Sherman Act violation). See also Truax v. Corrigan, 257 U.S. 312 (1921) (Van Devanter and McReynolds join opinion invalidating state statute barring injunctive relief against union picketing); Hitchman Coal \& Coke Co. v. Mitchell, 245 U.S. 229 (1917) (Van Devanter and McReynolds join opinion enjoining UMW's effort to unionize mine employees engaged under "yellow dog" contracts); Coppage v. Kansas, 236 U.S. 1 (1915) (Van Devanter and McReynolds join opinion invalidating state statute prohibiting "yellow dog" contracts). For an analysis of the applicability of antitrust law to union activity, see Daniel R. Ernst, The Labor Exemption, 1908-1914, 74 lowa L. Rev. 1151 (1989). For a discussion of the Court's yellow dog contract cases, see Barry Cushman, Doctrinal Synergies and Liberal Dilemmas: The Case of the Yellow Dog Contract, 1992 Sup. Ct. Rev. 235.

82259 U.S. 344 (1922).

${ }^{83}$ Id. at 407.

\&s Id. at 407-08 (emphasis added) (citations omitted).

ss Id. at 407-13 (emphasis added) (citations omitted).

86 265 U.S. 457 (1924).

${ }^{87}$ Id. at 471 (emphasis added).

289 U.S. 103 (1933).

89 Id. at 107 (emphasis added).

${ }^{90} \mathrm{Id}$. (emphasis added) (citations omitted).

91 Anderson v. Shipowners Ass'n, 272 U.S. 359, 364 (1926) (emphasis added).

${ }_{92}$ National Ass'n of Window Glass Mfrs. v. United States, 263 U.S. 403 (1923). See also Gompers v. Bucks Stove \& Range Co., 221 U.S. 418 (1911) (Van Devanter joins opinion reversing criminal contempt conviction of union officials for violating order enjoining a boycott).

${ }^{93}$ In addition to cases cited supra notes 77-80, compare, e.g., United States v. United States Steel Corp., 251 U.S. 417 (1920) (finding that U.S. Steel did not violate Sherman Act) (McReynolds takes no part) and United States v. E.C. Knight Co., 156 U.S. 1 (1895) (finding acquisition of local sugar refinery companies by corporation possessing $98 \%$ of the nation's sugar refining capacity did not violate the Sherman Act) with, e.g., Northern Sec. Co. v. United States, 193 U.S. 197 (1904) (finding railroad combination a restraint of trade); United States v. Joint-Traffic Ass'n, 171 U.S. 505 (1898) (finding railroad combination a restraint of trade) and United States v. Trans-Missouri Freight Ass'n, 166 U.S. 290 (1897) (finding contract between railroad companies void as a restraint of trade). See also Charles W. McCurdy, The Knight 
Sugar Decision of 1895 and the Modernization of American Corporation Law, 18691903, 53 Bus. Hist. Rev. 304 (1979).

${ }^{94}$ A.L.A. Schechter Poultry Corp. v. United States, 295 U.S. 495 (1935).

${ }^{95}$ United States v. Butler, 297 U.S. 1 (1936).

${ }^{96}$ Carter v. Carter Coal Co., 298 U.S. 238 (1936).

${ }^{97}$ See supra note 24.

${ }_{98}$ Pennsylvania R.R. v. United States R.R. Labor Bd., 261 U.S. 72 (1923).

${ }^{9}$ Texas \& N.O.R.R. v. Brotherhood of Ry. \& Steam Ship Clerks, 281 U.S. 548 (1930) (Van Devanter, Sutherland, and Butler join opinion) (McReynolds takes no part).

${ }^{100}$ Virginian Ry. Co. v. System Fed'n No. 40, 300 U.S. 515 (1937) (all Four Horsemen join opinion).

${ }^{101}$ See, e.g., NLRB v. Waterman S.S. Co., 309 U.S. 206 (1940) (McReynolds joins opinion supporting NLRB ruling ordering international steamship transport company to cease commission of unfair labor practices); NLRB v. MacKay Radio \& Tel. Co., 304 U.S. 333 (1938) (McReynolds and Butler join opinion supporting NLRB ruling ordering interstate communication company to cease commission of unfair labor practices); NLRB v. Pacific Greyhound Lines, Inc., 303 U.S. 272 (1938) (McReynolds and Butler join opinion supporting NLRB ruling ordering interstate transit company to cease commission of unfair labor practices); NLRB v. Pennsylvania Greyhound Lines, Inc., 303 U.S. 261 (1938) (McReynolds and Butler join opinion supporting NLRB ruling ordering interstate transit company to cease commission of unfair labor practices); Washington, V. \& M. Coach Co. v. NLRB, 301 U.S. 142 (1937) (all Four Horsemen join opinion supporting NLRB ruling ordering interstate transit company to cease commission of unfair labor practices). See also NLRB v. Newport News Shipbuilding \& Dry Dock Co., 308 U.S. 241 (1939) (McReynolds joins opinion supporting NLRB ruling ordering company to cease commission of unfair labor practices).

${ }^{102}$ See, e.g., NLRB v. Friedman-Harry Marks Clothing Co., 301 U.S. 58 (1937) (Van Devanter, Sutherland, and Butler join McReynolds' dissent arguing commerce power does not extend to intrastate manufacture of goods); NLRB v. Fruehauf Trailer Co., 301 U.S. 49 (1937) (same); NLRB v. Jones \& Laughlin Steel Corp., 301 U.S. 1 (1937) (same).

${ }^{103}$ See Sturges \& Burn Mfg. Co. v. Beauchamp, 231 U.S. 320 (1913).

${ }^{104}$ See Bailey v. Drexel Furniture Co., 259 U.S. 20 (1922); Hammer v. Dagenhart, 247 U.S. 251 (1918).

${ }^{105}$ Arthur M. Schlesinger, The State Rights Fetish, in New Viewpoints in American History 220 (1922).

${ }^{106}$ See National Licorice Co. v. NLRB, 309 U.S. 350 (1940) (McReynolds joins opinion supporting NLRB ruling ordering company to cease unfair labor practices); Ford Motor Co. v. NLRB, 305 U.S. 364 (1939) (McReynolds and Butler join opinion supporting NLRB ruling ordering company to cease unfair labor practices). I might also ask what you make of Milk Wagon Drivers' Union Local 753 v. Lake Valley Farm Prod., Inc., 311 U.S. 91 (1940) (McReynolds joins opinion affirming dismissal of action by retailer to enjoin union from picketing store), and Dorchy v. Kansas, 264 U.S. 286 (1924) and Charles Wolff Packing Co. v. Court of Indus. Relations of Kansas, 262 U.S. 522 (1923) (all Four Horsemen join opinions striking down Kansas Court of Industrial Relations Act, which instituted a system of compulsory arbitration of labor disputes and deprived unions of their rights to strike, boycott and picket). 
${ }^{107}$ See Herman Oliphant, A Return to Stare Decisis, 6 Am. L. Sch. Rev. 215 (1927).

${ }^{108}$ Lochner v. New York, 198 U.S. 45 (1905).

${ }^{109}$ See, e.g., Radice v. New York, 264 U.S. 292 (1924) (Van Devanter, McReynolds, and Butler join Sutherland's opinion upholding statute prohibiting employment of women in large-city restaurants between 10 p.m. and 6 a.m.); United States v. Brooklyn E. Dist. Terminal, 249 U.S. 296 (1919) (Van Devanter and McReynolds join opinion holding terminal subject to the Federal Hours of Service Act); Dominion Hotel, Inc. v. Arizona, 249 U.S. 265 (1919) (Van Devanter and McReynolds join opinion upholding statute limiting working hours of women in hotels); Chicago \& A.R.R. v. United States, 247 U.S. 197 (1918) (Van Devanter joins McReynolds' opinion affirming conviction for violation of the Federal Hours of Service Act); Atchison, T. \& S.F. Ry. v. United States, 244 U.S. 336 (1917) (Van Devanter joins opinion affirming conviction for violation of the Federal Hours of Service Act) (McReynolds takes no part); Bosley v. McLaughlin, 236 U.S. 385 (1915) (Van Devanter and McReynolds join opinion upholding maximum hours law for women); Miller v. Wilson, 236 U.S. 373 (1915) (Van Devanter and McReynolds join opinion upholding maximum hours law for women); Hawley v. Walker, 232 U.S. 718 (1914) (Van Devanter joins opinion upholding maximum hours law for women); Riley v. Massachusetts, 232 U.S. 671 (1914) (Van Devanter joins opinion upholding maximum hours law for women); Missouri-Kan.-Tex. Ry. v. United States, 231 U.S. 112 (1913) (Van Devanter joins opinion upholding convictions for violations of Federal Hours of Service Act); United States v. Garbish, 222 U.S. 257 (1911) (Van Devanter joins opinion strictly construing exceptions to an eight-hour workday law for public works); Baltimore \& O.R.R. v. ICC, 221 U.S. 612 (1911) (Van Devanter joins opinion upholding Federal Hours of Service Act).

${ }^{110}$ See West Coast Hotel Co. v. Parrish, 300 U.S. 379 (1937); Morehead v. New York ex rel. Tipaldo, 298 U.S. 587 (1936); Donham v. West-Nelson Mfg. Co., 273 U.S. 657 (1927); Murphy v. Sardell, 269 U.S. 530 (1925); Adkins v. Children's Hospital, 261 U.S. 525 (1923).

iII See, e.g., Letter from Edith Houghton Hooker to George Sutherland (April 5, 1937); Letter from Anna Keeton Wiley to George Sutherland (March 30, 1937); Letter from Ruth G. Williams to George Sutherland (June 3, 1936) (on file with the Virginia Law Review Association).

${ }^{112}$ See Thompson v. Lucas, 252 U.S. 358 (1920) (Van Devanter and McReynolds join opinion upholding provisions of Seamen's Act providing for payment of one-half wages on demand by seaman at port); Strathearn S.S. Co. v. Dillon, 252 U.S. 348 (1920) (Van Devanter and McReynolds join opinion upholding provisions of Seamen's Act providing for payment of one-half wages on demand by seaman at port); Rail \& River Coal Co. v. Yaple, 236 U.S. 338 (1915) (Van Devanter and McReynolds join opinion upholding statute directing that, where miners' wages were determined by the weight of the coal they mined, the weighing take place before the coal was screened); Keokee Consol. Coke Co. v. Taylor, 234 U.S. 224 (1914) (Van Devanter joins opinion upholding statute requiring that all store orders or other evidence of indebtedness issued by specified employers in payment of wages be redeemable in cash); Erie R.R. v. Williams, 233 U.S. 685 (1914) (Van Devanter joins opinion upholding statute requiring semi-monthly, cash payment of wages in specified industries); Charles W. McCurdy, The Liberty of Contract Regime in American Law (unpublished manuscript on file with the Virginia Law Review Association). 
${ }^{113}$ See, e.g., Brady v. Terminal R.R. Ass'n., 303 U.S. 10 (1938) (McReynolds and Butler join opinion upholding award under FSAA); Swinson v. Chicago, St. P., M. \& O. Ry., 294 U.S. 529 (1935) (all Four Horsemen join opinion reversing directed verdict for defendant under FSAA); Moore v. Chesapeake \& O. Ry., 291 U.S. 205 (1934) (upholding federal court's jurisdiction of employee's injury claims under the FSAA in connection with FELA by reversing a lower court determination adverse to employee, with all Four Horsemen joining opinion); Rocco v. Lehigh Valley R.R., 288 U.S. 275 (1933) (Van Devanter and Sutherland join opinion upholding award under FELA) (McReynolds and Butler dissent); Jamison v. Encarnacion, 281 U.S. 635 (1930) (Van Devanter, McReynolds, and Sutherland join Butler's opinion affirming award under FELA for injuries sustained by stevedore assaulted by his foreman); Chicago, R.I. \& Pac. Ry. v. Ward, 252 U.S. 18 (1920) (Van Devanter and McReynolds join opinion affirming award under FELA); Louisville \& Nash. R.R. v. Holloway, 246 U.S. 525 (1918) (Van Devanter and McReynolds join opinion affirming award under FELA); Union Pac. R.R. v. Hadley, 246 U.S. 330 (1918) (Van Devanter and McReynolds join opinion affirming judgment for employee under FELA); Great N. Ry. v. Donaldson, 246 U.S. 121 (1918) (Van Devanter and McReynolds join opinion affirming award under FELA); Union Pac. R.R. v. Huxoll, 245 U.S. 535 (1918) (Van Devanter and McReynolds join opinion affirming award under FELA and FSAA); Washington Ry. \& Elec. Co. v. Scala, 244 U.S. 630 (1917) (Van Devanter and McReynolds join opinion affirming award under FELA); New York Cent. \& H.R.R.R. v. Tonsellito, 244 U.S. 360 (1917) (Van Devanter joins McReynolds' opinion affirming award under FELA); Minneapolis \& St. L.R.R. v. Gotschall, 244 U.S. 66 (1917) (Van Devanter and McReynolds join opinion affirming award under FELA); St. Joseph \& G.I. Ry. v. Moore, 243 U.S. 311 (1917) (Van Devanter and McReynolds join opinion affirming award under FELA and FSAA); Illinois Cent. R.R. v. Williams, 242 U.S. 462 (1917) (Van Devanter and McReynolds join opinion affirming award under FSAA); Baltimore \& O.R.R. v. Wilson, 242 U.S. 295 (1916) (Van Devanter and McReynolds join opinion affirming award under FELA); Baltimore \& O.R.R. v. Whitacre, 242 U.S. 169 (1916) (Van Devanter and McReynolds join opinion affirming award under FELA); Atlantic City R.R. v. Parker, 242 U.S. 56 (1916) (Van Devanter and McReynolds join opinion affirming award under FELA); Spokane \& 1. Emp. R.R. v. Campbell, 241 U.S. 497 (1916) (Van Devanter and McReynolds join opinion affirming award under FELA and FSAA); San Antonio \& Ark. Pass Ry. v. Wagner, 241 U.S. 476 (1916) (Van Devanter and McReynolds join opinion affirming award under FELA and FSAA); Chicago \& N.W. Ry. v. Bower, 241 U.S. 470 (1916) (Van Devanter and McReynolds join opinion affirming award under FELA); Chesapeake \& O. Ry. v. Proffitt, 241 U.S. 462 (1916) (Van Devanter and McReynolds join opinion affirming award under FELA); Seaboard Air Line Ry. v. Renn, 241 U.S. 290 (1916) (McReynolds joins Van Devanter's opinion affirming award under FELA); Louisville \& Nash. R.R. v. Stewart, 241 U.S. 261 (1916) (Van Devanter and McReynolds join opinion affirming award under FELA); Chesapeake \& O. Ry. v. Carnahan, 241 U.S. 241 (1916) (Van Devanter and McReynolds join opinion affirming award under FELA); St. Louis \& S.F.R.R. v. Brown, 241 U.S. 223 (1916) (Van Devanter and McReynolds join opinion affirming award under FELA); Minneapolis \& St. L.R.R. v. Bombolis, 241 U.S. 211 (1916) (Van Devanter and McReynolds join opinion affirming award under FELA); Texas \& Pac. Ry. v. Rigsby, 241 U.S. 33 (1916) (Van Devanter and McReynolds join opinion affirming award under FSAA); Seaboard Air Line Ry. v. Kenney, 240 U.S. 489 (1916) (Van-Devanter and McReynolds join opinion affirming award under FELA); Great N. Ry. v. Knapp, 
240 U.S. 464 (1916) (Van Devanter and McReynolds join opinion affirming award under FELA); Illinois Cent. R.R. v. Skaggs, 240 U.S. 66 (1916) (Van Devanter and McReynolds join opinion affirming award under FELA notwithstanding error in contributory negligence instruction); Chicago, R.I. \& Pac. Ry. v. Wright, 239 U.S. 548 (1916) (McReynolds joins Van Devanter's opinion affirming award under FELA); Chicago \& A.R.R. v. Wagner, 239 U.S. 452 (1915) (Van Devanter and McReynolds join opinion affirming award under FELA and invalidating company's attempt to contract out of liability under the Act); Seaboard Air Line Ry. v. Koennecke, 239 U.S. 352 (1915) (Van Devanter and McReynolds join opinion affirming award under FELA); Great N. Ry. v. Otos, 239 U.S. 349 (1915) (Van Devanter and McReynolds join opinion affirming award under FELA and FSAA); Norfolk S.R.R. v. Ferebee, 238 U.S. 269 (1915) (Van Devanter and McReynolds join opinion affirming award under FELA); New York Cent. \& H.R.R.R. v. Carr, 238 U.S. 260 (1915) (Van Devanter and McReynolds join opinion affirming award under FELA); Yazoo \& Miss. Valley R.R. v. Wright, 235 U.S. 376 (1914) (Van Devanter and McReynolds join opinion affirming award under FELA); Southern Ry. v. Crockett, 234 U.S. 725 (1914) (Van Devanter joins opinion affirming award under FELA and FSAA); Grand Trunk W. Ry. v. Lindsay, 233 U.S. 42 (1914) (Van Devanter joins opinion affirming award under FELA); Chicago, R.I. \& Pac. Ry. v. Brown, 229 U.S. 317 (1913) (Van Devanter joins opinion affirming award under FELA and FSAA); Norfolk \& W. Ry. v. Earnest, 229 U.S. 114 (1913) (Van Devanter writes opinion affirming award under FELA); Philadelphia, B. \& W.R.R. v. Schubert, 224 U.S. 603 (1912) (Van Devanter joins opinion affirming award under FELA and invalidating company's attempt to contract out of liability under the Act); Chicago Junction Ry. v. King, 222 U.S. 222 (1911) (Van Devanter joins opinion affirming award under FSAA); Chicago, B. \& Q. Ry. v. United States, 220 U.S. 559 (1911) (Van Devanter joins opinion upholding award under FSAA).

${ }^{114}$ See, e.g., Baltimore \& O.S.W.R.R. v. Burtch, 263 U.S. 540 (1924) (Van Devanter, McReynolds, and Butler join Sutherland's opinion holding that bystander enlisted by conductor to unload heavy freight at station was employed in interstate commerce); Erie R.R. v. Szary, 253 U.S. 86 (1920) (McReynolds joins opinion holding that an employee whose duty it was to dry sand in stoves in a small structure near the tracks and to supply it to locomotives used in both inter-and intrastate commerce, injured while returning from getting a drink of water when returning from an ash-pit whither he had gone to dump ashes taken by him from one of the stoves after sanding locomotives bound for other states, was employed in interstate commerce) (Van Devanter dissents); Erie R.R. v. Collins, 253 U.S. 77 (1920) (McReynolds joins opinion holding that employee injured while running a gasoline engine to pump water into a tank for use by locomotives was employed in interstate commerce) (Van Devanter dissents); Kinzell v. Chicago, M. \& S.P. Ry., 250 U.S. 130 (1919) (Van Devanter and McReynolds join opinion holding that employee injured while removing dirt and stones from track was employed in interstate commerce); Southern Ry. v. Puckett, 244 U.S. 571 (1917) (Van Devanter and McReynolds join opinion holding that employee who tripped in a train yard while on his way to assist in the rescue of a fellow employee trapped under a wrecked car was employed in interstate commerce); Minneapolis \& St. L.R.R. v. Winters, 242 U.S. 353 (1917) (Van Devanter and McReynolds join opinion upholding judgment for injured employee notwithstanding fact that employee was not engaged in interstate commerce at time of injury, because defendant did not object to the application of FELA at trial); Pedersen v. Delaware, $L$. \& W.R.R., 229 U.S. 146 (1913) (Van Devanter writes opinion holding that an em- 
ployee injured while carrying bolts to be used to repair a railroad bridge used by interstate trains was employed in interstate commerce).

us 250 U.S. 101 (1919).

${ }^{116}$ McLeod v. Threlkeld, 319 U.S. 491 (1943).

${ }^{117}$ See, e.g., Alaska Packers Ass'n v. Industrial Accident Comm'n, 294 U.S. 532 (1935) (all Four Horsemen join opinion upholding provisions of California's statute); Crowell v. Benson, 285 U.S. 22 (1932) (upholding Longshoremen's and Harbor Worker's Compensation Act, with all Four Horsemen joining opinion); Staten Island Rapid Transit Ry. v. Phoenix Indem. Co., 281 U.S. 98 (1930) (all Four Horsemen join opinion upholding provisions of New York's statute); Booth Fisheries Co. v. Industrial Comm'n, 271 U.S. 208 (1926) (all Four Horsemen join opinion upholding provisions of Wisconsin's statute); R.E. Sheehan Co. v. Shuler, 265 U.S. 371 (1924) (all Four Horsemen join opinion upholding provisions of New York's statute); Cudahy Packing Co. v. Parramore, 263 U.S. 418 (1923) (Van Devanter joins Sutherland's opinion upholding provisions of Utah's statute) (Butler and McReynolds dissent); Madera Sugar Pine Co. v. Industrial Accident Comm'n, 262 U.S. 499 (1923) (all Four Horsemen join opinion upholding provisions of California's statute); Ward \& Gow v. Krinsky, 259 U.S. 503 (1922) (Van Devanter joins opinion upholding provisions of New York's statute) (McReynolds dissents); Lower Vein Coal Co. v. Industrial Bd., 255 U.S. 144 (1921) (Van Devanter and McReynolds join opinion upholding provisions of Indiana's statute); New York Cent. R.R. v. Bianc, 250 U.S. 596 (1919) (Van Devanter joins opinion upholding provision of New York's statute) (McReynolds dissents); Hawkins v. Bleakly, 243 U.S. 210 (1917) (Van Devanter and McReynolds join opinion upholding Iowa's statute); New York Cent. R.R. v. White, 243 U.S. 188 (1917) (Van Devanter and McReynolds join opinion upholding New York's statute).

"1s See, e.g., Carlin Constr. Co. v. Heaney, 299 U.S. 41 (1936) (Van Devanter, Sutherland, and Butler join McReynolds' opinion upholding award despite claim that it intruded upon the maritime jurisdiction); Ohio v. Chattanooga Boiler \& Tank Co., 289 U.S. 439 (1933) (all Four Horsemen join opinion upholding award); Voehl v. Indemnity Ins. Co., 288 U.S. 162 (1933) (all Four Horsemen join opinion upholding award under Longshoremen's and Harbor Workers' Compensation Act); Boston \& Me. R.R. v. Armburg, 285 U.S. 234 (1932) (all Four Horsemen join opinion upholding award); Bountiful Brick Co. v. Giles, 276 U.S. 154 (1928) (Van Devanter, McReynolds, and Butler join Sutherland's opinion upholding award); Millers' Indem. Underwriters v. Braud, 270 U.S. 59 (1926) (Van Devanter, Sutherland, and Butler join McReynolds' opinion affirming state workmen's compensation award); State Indus. Comm'n v. Nordenholt Corp., 259 U.S. 263 (1922) (Van Devanter joins McReynolds' opinion reversing judgment vacating award). See also United States v. Arzner, 287 U.S. 470 (1933) (Van Devanter, Sutherland, and Butler join McReynolds' opinion upholding award under World War Veterans' Act); Baltimore \& Philadelphia Steamboat Co. v. Norton, 284 U.S. 408 (1932) (Van Devanter, Sutherland, and McReynolds join Butler's opinion upholding award under Longshoremen's and Harbor Workers' Compensation Act).

"19 See, e.g., Vandenbark v. Owens-Ill. Glass Co., 311 U.S. 538, 543 (1941) (McReynolds concurs in result of opinion reversing dismissal of employee's action); Warner v. Goltra, 293 U.S. 155 (1934) (all Four Horsemen join opinion reversing dismissal of employee's action under Merchant Marine Act of 1920); Vancouver S.S. Co. v. Rice, 288 U.S. 445 (1933) (Van Devanter, McReynolds, and Sutherland join Butler's opinion affirming judgment giving decedent stevedore's administratrix a cause of action enforceable in admiralty in rem against the vessel on which the inju- 
ries were sustained); Cortes v. Baltimore Insular Line, Inc., 287 U.S. 367 (1932) (all Four Horsemen join opinion holding that failure to furnish adequate care to a seaman stricken with pneumonia was a personal injury giving the seaman's administrator a cause of action against the employer under the Merchant Marine Act of 1920); Uravic v. F. Jarka Co., 282 U.S. 234 (1931) (all Four Horsemen join opinion interpreting broadly the term "seaman" in the Merchant Marine Act so as to create a cause of action for a stevedore injured while unloading a ship flying the German flag); Gonsalves v. Morse Dry Dock \& Repair Co., 266 U.S. 171 (1924) (Van Devanter, Sutherland, and Butler join McReynolds' opinion interpreting jurisdiction of admiralty court widely enough to allow it to hear an employee's personal injury claim); Great Lakes Dredge \& Dock Co. v. Kierejewski, 261 U.S. 479 (1923) (Van Devanter, Sutherland, and Butler join McReynolds' opinion upholding federal district court's jurisdiction to entertain wrongful death action); Fillippon v. Albion Vein Slate Co., 250 U.S. 76 (1919) (Van Devanter and McReynolds join opinion reversing judgment for employer on grounds that jury instruction was erroneous); Erie R.R. v. Purucker, 244 U.S. 320 (1917) (Van Devanter and McReynolds join opinion affirming judgment for employee); Ohio River Contract Co. v. Gordon, 244 U.S. 68 (1917) (Van Devanter and McReynolds join opinion affirming judgment for employee); Louisville \& Nash. R.R. v. Layton, 243 U.S. 617 (1917) (Van Devanter and McReynolds join opinion affirming judgment for employee); Erie R.R. v. Welsh, 242 U.S. 303 (1916) (Van Devanter and McReynolds join opinion affirming judgment for employee); Louisville \& Nash. R.R. v. Parker, 242 U.S. 13 (1916) (Van Devanter and McReynolds join opinion affirming judgment for employee); Brown v. Pacific Coast Coal Co., 241 U.S. 571 (1916) (Van Devanter and McReynolds join opinion affirming judgment for employee); Chicago, B. \& Q.R.R. v. Harrington, 241 U.S. 177 (1916) (Van Devanter and McReynolds join opinion affirming judgment for employee); Osborne v. Gray, 241 U.S. 16 (1916) (Van Devanter and McReynolds joins opinion affirming judgment for employee); Myers v. Pittsburgh Coal Co., 233 U.S. 184 (1914) (Van Devanter joins opinion affirming judgment for employee); Gila Valley, G. \& N. Ry. v. Hall, 232 U.S. 94 (1914) (Van Devanter joins opinion affirming judgment for employee); Texas \& Pac. Ry. v. Harvey, 228 U.S. 319 (1913) (Van Devanter joins opinion affirming judgment for employee); George A. Fuller Co. v. McCloskey, 228 U.S. 194 (1913) (Van Devanter joins opinion affirming judgment for employee).

${ }^{120}$ See, e.g., Socony-Vacuum Oil Co. v. Smith, 305 U.S. 424 (1939) (Butler joins opinion affirming judgment for injured seaman and holding that assumption of risk was not a defense under the Jones Act) (McReynolds dissents, contending that the trial court erroneously refused defendant's request for a jury instruction on the availability of an assumption of risk defense); Beadle v. Spencer, 298 U.S. 124 (1936) (all Four Horsemen join opinion affirming judgment for injured seaman and holding that neither assumption of risk nor contributory negligence were defenses in actions under the Jones Act or the maritime law); The Arizona v. Anelich, 298 U.S. 110 (1936) (all Four Horsemen join opinion affirming a judgment for an injured seaman and holding that assumption of risk was not a defense under the Jones Act); Phillips Petroleum Co. v. Jenkins, 297 U.S. 629 (1936) (Van Devanter, McReynolds, and Sutherland join Butler's opinion affirming judgment for employee and holding constitutional an Arkansas statute abrogating the fellow servant rule in cases involving corporate defendants); Bowersock v. Smith, 243 U.S. 29 (1917) (Van Devanter and McReynolds join opinion affirming judgment for employee and upholding provisions of a Kansas statute abrogating the fellow servant rule and the doctrines of contributory negligence and assumption of risk); Jeffrey Mfg. Co. v. Blagg, 235 U.S. 571 
(1915) (Van Devanter and McReynolds join opinion affirming judgment for employee and upholding Ohio statute abrogating the fellow servant rule and the doctrines of contributory negligence and assumption of risk); Chicago, Ind. \& L. Ry. v. Hackett, 228 U.S. 559 (1913) (Van Devanter joins opinion affirming judgment for employee and upholding Indiana statute abrogating fellow servant rule in railroad cases); Missouri Pac. Ry. v. Castle, 224 U.S. 541 (1912) (Van Devanter joins opinion affirming judgment for employee and upholding Nebraska statute abrogating the fellow servant rule and the doctrine of contributory negligence in railroad cases).

${ }^{121}$ See, e.g., Sibbach v. Wilson \& Co., 312 U.S. 1 (1941) (McReynolds joins opinion overturning contempt conviction of plaintiff for refusing to submit to a physical examination); The Admiral Peoples, 295 U.S. 649 (1935) (holding that an allegation of negligence against a ship was in admiralty and as a result the suit could go forward, with all Four Horsemen joining opinion); Fairport, P. \& E.R.R. v. Meredith, 292 U.S. 589 (1934) (Van Devanter, McReynolds, and Butler join Sutherland's opinion affirming judgment for plaintiff notwithstanding her contributory negligence); Pokora v. Wabash Ry., 292 U.S. 98 (1934) (all Four Horsemen join opinion reversing a judgment directing a verdict for the defendant); Best v. District of Columbia, 291 U.S. 411 (1934) (all Four Horsemen join opinion reversing judgment directing a verdict for the defendant); Miller v. Union Pac. R.R., 290 U.S. 227 (1933) (Van Devanter, McReynolds, and Butler join Sutherland's opinion reversing judgment dismissing plaintiff's petition); Atlantic Coast L.R.R. v. Ford, 287 U.S. 502 (1933) (Van Devanter, McReynolds, and Butler join Sutherland's opinion affirming judgment for plaintiff and upholding statute creating rebuttable presumption of railroad's negligence); Seaboard Air Line Ry. v. Watson, 287 U.S. 86 (1932) (Van Devanter, McReynolds, and Sutherland join Butler's opinion dismissing defendant's appeal notwithstanding trial court's erroneous refusal to instruct the jury on the issue of contributory negligence, and upholding statute creating rebuttable presumption of railroad's negligence); Louis Pizitz Dry Goods Co. v. Yeldell, 274 U.S. 112 (1927) (all Four Horsemen join opinion affirming judgment for plaintiff and upholding statute allowing punitive damage awards in respondeat superior wrongful death cases); Doullut \& Williams Co. v. United States, 268 U.S. 33 (1925) (Van Devanter, Sutherland, and Butler join McReynolds' opinion reversing judgment dismissing libels for want of admiralty jurisdiction); Union Pac. R.R. v. Burke, 255 U.S. 317 (1921) (Van Devanter and McReynolds join opinion affirming judgment for plaintiff and ruling that railroad carriers cannot limit their common law liability by contracting for exemption from the consequences of their own negligence); Panama R.R. v. Toppin, 252 U.S. 308 (1920) (Van Devanter and McReynolds join opinion affirming judgment for plaintiff); New York Cent. R.R. v. Mohney, 252 U.S. 152 (1920) (McReynolds joins, Van Devanter concurs in opinion affirming judgment for plaintiff); Chicago, R.I. \& Pac. Ry. v. Cole, 251 U.S. 54 (1919) (Van Devanter and McReynolds join opinion affirming judgment for plaintiff); Norfolk S.R.R. v. Chatman, 244 U.S. 276 (1917) (Van Devanter and McReynolds join opinion affirming judgment for plaintiff and voiding stipulation in drover's pass exempting carrier from liability for personal injuries caused by its own negligence); Chicago \& A.R.R. v. McWhirt, 243 U.S. 422 (1917) (McReynolds joins Van Devanter's opinion affirming judgment for plaintiff); McAllister v. Chesapeake \& O. Ry., 243 U.S. 302 (1917) (Van Devanter and McReynolds join opinion reversing dismissal of plaintiff's action); Memphis St. Ry. v. Moore, 243 U.S. 299 (1917) (Van Devanter and McReynolds join opinion affirming judgment for plaintiff); Munsey v. Webb, 231 U.S. 150 (1913) (Van Devanter joins opinion affirming judgment for plaintiff); Texas \& Pac. Ry. v. Stewart, 228 U.S. 357 (1913) (Van Devanter joins 
opinion affirming judgment for plaintiff); Southern Pac. Co. v. Schuyler, 227 U.S. 601 (1913) (Van Devanter joins opinion affirming judgment for plaintiff).

${ }^{122}$ See Michael E. Parrish, Anxious Decades: America in Prosperity and Depression 1920-1941, 104 (1992).

${ }^{123}$ See Gambino v. United States, 275 U.S. 310 (1927) (all Four Horsemen join opinion holding that the Fourth Amendment barred introduction at federal trial of evidence seized by New York state police from accused's automobile without a warrant and without probable cause, and turned over to federal authorities for prosecution).

${ }^{124}$ See United States v. Lefkowitz, 285 U.S. 452 (1932) (Van Devanter, McReynolds, and Sutherland join Butler's opinion reversing conviction where police acting pursuant to an arrest warrant for violation of the liquor laws arrested defendants at their place of business and proceeded to search desks and filing cabinets in the office, and to seize various papers for use against the defendants at trial, on ground that the papers had not been in plain view and the search of the desks and cabinets was therefore not a lawful search incident to arrest).

${ }^{125} 238$ U.S. 62 (1915).

${ }^{126}$ Id. at 66. Accord, Adams Express Co. v. Kentucky, 238 U.S. 190, 202 (1915). See also United States v. Hill, 248 U.S. 420, 428 (1919) (McReynolds, J., dissenting) (contending that the Reed "Bone-Dry" Amendment, as construed by the majority, was unconstitutional).

127287 U.S. 206 (1932).

${ }^{128} 287$ U.S. 124 (1932).

${ }^{129}$ See also United States v. La Franca, 282 U.S. 568 (1931) (each of his fellow Horsemen joins Sutherland's opinion construing a "tax" under the Prohibition Act as not truly a tax but instead a penalty, and holding that a civil action to recover such tax was barred by a prior conviction based upon the same transaction); Corneli v. Moore, 257 U.S. 491 (1922) (McReynolds dissents from opinion holding that owner of liquor store who paid tax on liquor purchased before ratification of the Eighteenth Amendment was not deprived of due process by being prevented from taking the liquor home for personal consumption following ratification); Vigliotti v. Pennsylvania, 258 U.S. 403 (1922) (McReynolds dissents from opinion affirming conviction of man accused of selling liquor without a license); United States v. Yuginovich, 256 U.S. 450 (1921) (Van Devanter and McReynolds join opinion upholding motion to quash indictment against defendant charged with not paying taxes on distilled spirits). For the origins of the tax/penalty distinction in the Four Horsemen's jurisprudence, see Bailey v. Drexel Furniture Co., 259 U.S. 20 (1922).

${ }^{130} 277$ U.S. 438, 485 (1928) (Butler, J., dissenting).

131302 U.S. 379 (1937).

${ }_{132}$ Weiss v. United States, 308 U.S. 321 (1939). See also United States v. Falcone, 311 U.S. 205 (1940) (McReynolds joins opinion reversing conviction of the Falcone and Nole brothers and Henry Alberico for conspiring to violate the revenue laws by selling goods to a person whom they knew was going to use the goods to make illegal alcohol).

${ }^{133} 267$ U.S. 132 (1925).

${ }^{134}$ Id. at 163 (McReynolds and Sutherland, JJ., dissenting). Compare Justice Butler on circuit in United States v. Motlow, 10 F.2d 657, 662 (1926) ("Abhorrence, however great, of persistent and menacing crime will not excuse transgression in the courts of 
the legal rights of the worst offenders."). See David J. Danelski, A Supreme Court Justice is Appointed, 182 (1964).

${ }^{135}$ Carroll, 267 U.S. at 163 (McReynolds, J., dissenting).

${ }^{136} \mathrm{ld}$. at 169 (McReynolds, J., dissenting).

137287 U.S. 435 (1932).

138290 U.S. 41 (1933).

${ }^{139} 291$ U.S. 217 (1934).

${ }^{140}$ See also Fleisher v. United States, 302 U.S. 218 (1937) (per curiam) (McReynolds, Sutherland, and Butler join opinion overturning a conviction of conspiracy to possess products used to distill spirits unlawfully on the ground that the indictment failed to state an offense); United States v. Constantine, 296 U.S. 287 (1935) and United States v. Kesterson, 296 U.S. 299 (1935) (all Four Horsemen join opinions overturning convictions of liquor dealers for failure to pay a federal excise of $\$ 1,000$ imposed upon those selling alcohol contrary to state or local law, interpreting the excise as a penalty for violation of state law rather than a true tax, and accordingly invalidating it on Tenth Amendment grounds); Cook v. United States, 288 U.S. 102 (1933), (McReynolds joins opinion construing a treaty with Britain detailing the rights of the United States to seize British ships suspected of smuggling liquor into the United States not to allow the particular search in question) (Butler and Sutherland dissent) (Van Devanter takes no part); Taylor v. United States, 286 U.S. 1 (1932) (Van Devanter, Sutherland, and Butler join McReynolds' opinion reversing conviction based on evidence secured through warrantless search of garage from which Prohibition agents had detected the odor of whiskey); Dunn v. United States, 284 U.S. 390, 394 (1932) (Butler, J., dissenting) (stating that he would reverse the conviction of Dunn under the National Prohibition Act, on ground that possession of illegal alcohol not proved); Go-Bart Importing Co. v. United States, 282 U.S. 344 (1931) (Van Devanter, McReynolds, and Sutherland join Butler's opinion overturning convictions and invalidating exploratory search conducted by Prohibition agents acting pursuant to an invalid arrest warrant and without a search warrant, who obtained incriminating evidence by using threats of force to coerce defendant to open a desk and safe); Byars v. United States, 273 U.S. 28 (1927) (Van Devanter, McReynolds, and Butler join Sutherland opinion overturning conviction of defendant charged with possession with intent to defraud of counterfeit strip stamps of the kind used upon whiskey bottled in bond, on grounds that evidence found by federal agent while accompanying state agents on a search of defendant's home under authority of a defective state search warrant, but without a federal warrant, could not be used in a federal trial); Lambert v. Yellowley, 272 U.S. 581, 597 (1926) (McReynolds, Sutherland, and Butler, dissenting, vote to invalidate a federal statute strictly regulating the amount of alcohol a physician could prescribe for medicinal use); United States y. One Ford Coupe Automobile, 272 U.S. 321, 335 (1926) (McReynolds, Sutherland, and Butler dissent from opinion upholding and interpreting broadly various seizure and taxation provisions of the Supplementary Prohibition Act); Samuels v. McCurdy, 267 U.S. 188, 200 (1925) (Butler dissents from opinion, which McReynolds, Sutherland, and Van Devanter join, upholding Georgia statute authorizing seizure and destruction of alcohol that had been purchased legally before the enactment of the statute); and Amos v. United States, 255 U.S. 313 (1921) (Van Devanter and McReynolds join opinion reversing conviction for illegal possession of whiskey where evidence of the infraction had been secured through a warrantless search of the defendant's home, which the defendant's wife had permitted under conditions of "implied coercion"). 
${ }^{1} 211$ U.S. 394 (1916).

${ }^{142}$ See also McGinis v. California, 247 U.S. 91 (1918), 247 U.S. 95 (1918) (Van Devanter and McReynolds join opinions reversing California state convictions for possession of opium and cocaine on Commerce Clause grounds).

${ }^{443} 249$ U.S. 86 (1919) (reversing decision sustaining demurrer of indictment of physician charged with prescribing drugs in a manner proscribed by the Act).

${ }^{14}$ Id. at 95 (White, C.J., and McKenna, Van Devanter, and McReynolds, JJ., dissenting); see also Webb v. United States, 249 U.S. 96, 100 (1919) (White, C.J., and McKenna, Van Devanter, and McReynolds, JJ., dissenting from opinion upholding the conviction of a physician for prescribing morphine to a habitual user).

145268 U.S. 5 (1925).

${ }^{146}$ Id. at 18, 22.

${ }^{147}$ Nigro v. United States, 276 U.S. 332, 354 (1928) (McReynolds and Sutherland, JJ., dissenting); Id. at 357 (Butler and Sutherland, JJ., dissenting).

148276 U.S. 413 (1928).

149 Id. at 420 (McReynolds and Butler, JJ., dissenting).

${ }^{150}$ Id. at 421 (Brandeis and Butler, JJ., dissenting).

${ }^{151}$ Id. at 426 (Butler, J., dissenting). Cf. United States v. Behrman, 258 U.S. 280, 289 (1922) (McReynolds joins dissent from opinion reversing judgment sustaining demurrer to indictment under the Act).

152269 U.S. 360 (1926).

153 Id. at 364.

1s4 Agnello v. United States, 269 U.S. 20, 32-33 (1925).

${ }^{15 s} 306$ U.S. 451 (1939).

${ }^{156}$ See Caminetti v. United States, 242 U.S. 470 (1917); Wilson v. United States, 232

U.S. 563 (1914); Hoke v. United States, 227 U.S. 308 (1913).

157 Gebardi v. United States, 287 U.S. 112 (1932).

158285 U.S. 424, 427 (1932) (McReynolds, J., dissenting).

159 Id. at 425.

${ }^{160} 232$ U.S. 383 (1914); see also Gouled v. United States, 255 U.S. 298 (1921); Silverthorne Lumber Co. v. United States, 251 U.S. 385 (1920).

161274 U.S. 220 (1927).

162297 U.S. 278 (1936).

${ }^{163}$ See Richard C. Cortner, A "Scottsboro" Case In Mississippi: The Supreme Court and Brown y. Mississippi (1986).

${ }^{164}$ Ziang Sung Wan v. United States, 266 U.S. 1 (1924) (all Four Horsemen joining opinion).

${ }^{165}$ Chambers v. Florida, 309 U.S. 227 (1940) (McReynolds, the sole remaining Horseman, joining opinion).

166308 U.S. 287 (1939).

${ }^{167}$ See also Arndstein v. McCarthy, 254 U.S. 71 (1920) (Van Devanter joins McReynolds' opinion holding that involuntary bankruptcy did not waive privilege against self-incrimination by disclosing to the court schedules showing assets and liabilities).

${ }^{168} 267$ U.S. 517 (1925).

${ }^{169}$ Id. 

ing).

${ }_{170} 291$ U.S. 97; 123 (1934) (Roberts, Brandeis, Sutherland, and Butler, JJ., dissent171282 U.S. 687 (1931).

172287 U.S. 45 (1932) (Butler and McReynolds dissent).

${ }^{173}$ See also Dan T. Carter, Scottsboro: A Tragedy of the American South (rev. ed. 1979).

${ }^{174} 283$ U.S. 308 (1931).

${ }^{175}$ See Smith v. Texas, 311 U.S. 128 (1940) (McReynolds joins opinion reversing the rape conviction of a black man indicted by an all-white grand jury); Pierre v. Louisiana, 306 U.S. 354 (1939) (McReynolds and Bulter join opinion voiding the indictment of a black man for the murder of a white man by a grand jury from which blacks had been systematically excluded); Hale v. Kentucky, 303 U.S. 613 (1938) (per curiam) (McReynolds and Butler joining a similar opinion); Hollins v. Oklahoma, 295 U.S. 394 (1935) (per curiam) (all Four Horsemen joining opinion to the same effect); Norris v. Alabama, 294 U.S. 587 (1935) (Van Devanter, Sutherland, and Butler join opinion reversing conviction in the second trial of Clarence Norris, one of the "Scottsboro boys," on the ground that blacks had been systematically excluded from jury service in the county in which he had been tried) (McReynolds takes no part in the decision); Patterson v. Alabama, 294 U.S. 600 (1935) (Van Devanter, Sutherland, and Butler join opinion reversing conviction of another "Scottsboro boy," Haywood Patterson, on the same ground) (McReynolds takes no part in the decision).

${ }_{176}$ United States v. Wood, 299 U.S. 123, 151 (1936) (McReynolds, Sutherland, and Butler, JJ., dissenting).

${ }^{n}$ District of Columbia v. Colts, 282 U.S. 63 (1930).

${ }^{178}$ District of Columbia v. Clawans, 300 U.S. 617, 633 (1937) (opinion of McReynolds and Butler, JJ.).

${ }^{179} 295$ U.S. 78 (1935).

${ }^{180} 261$ U.S. 86 (1923).

${ }^{181}$ Id. at 87, 92; see Richard C. Cortner, A Mob Intent on Death: The NAACP and the Arkansas Riot Cases (1988).

182 Berger v. United States, 255 U.S. 22 (1921).

${ }^{183} 254$ U.S. 135, 139 (1920) (McReynolds, J., dissenting).

18289 U.S. 466 (1933).

185290 U.S. 389 (1933).

${ }^{186} 273$ U.S. 583 (1927).

${ }^{187} 273$ U.S. 510 (1927).

${ }^{188}$ Id. at $518-19,532$.

${ }^{189}$ United States v. Benz, 282 U.S. 304 (1931).

${ }^{190} 267$ U.S. 87 (1925).

${ }^{191}$ Id. at $107-08,122$.

192302 U.S. 319 (1937).

${ }^{193}$ See, e.g., United States v. Durkee Famous Foods, 306 U.S. 68 (1939) (upholding reversal of criminal indictment because of statute of limitations, with Butler joining McReynolds' opinion); United States v. Raynor, 302 U.S. 540, 552 (1938) (Sutherland, J., dissenting) (McReynolds and Butler joining dissent from opinion reversing appellate court ruling which overturned a criminal conviction for counterfeiting); Lindsey v. Washington, 301 U.S. 397 (1937) (reversing grand larceny conviction because defendant was sentenced under law passed after crime was committed, 
with Butler, McReynolds, and Sutherland joining opinion); Valentine v. United States ex rel. Neidecker, 299 U.S. 5 (1936) (declaring that, unless specifically granted power by Congress, the executive has no power to extradite fugitive criminals, with all Four Horseman joining opinion); Hill v. United States ex rel. Wampler, 298 U.S. 460 (1936) (rejecting addition to sentence requiring that defendant remain in prison until a fine is paid, with all Four Horseman joining opinion); United States v. Hastings, 296 U.S. 188 (1935) (ruling that Court must accept construction of indictment by district court in affirming a dismissal of a criminal indictment under the Warehouse Act, with all Four Horseman joining opinion); Escoe v. Zerbst, 295 U.S. 490 (1935) (granting habeas corpus petition to probationer who was detained without a hearing, with all Four Horseman joining opinion); Mooney v. Holohan, 294 U.S. 103 (1935) (per curiam) (holding that criminal conviction obtained by prosecutors who knowingly relied on perjured testimony in order to convict violated due process, with all Four Horseman joining opinion); Factor v. Laubenheimer, 290 U.S. 276, 305 (1933) (Butler dissents from opinion, in which McReynolds, Sutherland, and Van Devanter join, upholding extradition of defendant to foreign country, even though crime committed overseas was not a crime in the United States); Shepard v. United States, 290 U.S. 96 (1933) (disallowing as too prejudicial the written statement by dying wife that her husband poisoned her, with all Four Horsemen joining opinion); South Carolina v. Bailey, 289 U.S. 412, 422 (1933) (Butler dissents from opinion, written by McReynolds and joined by Sutherland and Van Devanter, setting high standard for habeas corpus petitioner to meet in order to prevent extradition to another state for murder indictment); Cline v. Frink Dairy Co., 274 U.S. 445 (1927) (declaring unconstitutional a state antitrust statute because it lacked a fixed standard of guilt, with all Four Horsemen joining opinion); Connally v. General Constr. Co., 269 U.S. 385 (1926) (declaring unconstitutional as violating due process a criminal statute because of its vagueness, with Butler, McReynolds, and Van Devanter joining Sutherland's opinion); Salinger v. Loisel, 265 U.S. 224 (1924) (construing in favor of criminal defendant one's right to challenge prosecution under a habeas corpus proceeding, with Butler, McReynolds, and Sutherland joining Van Devanter's opinion); United States v. Moreland, 258 U.S. 433 (1922) (affirming reversal of criminal sentence because of lack of indictment by grand jury, with McReynolds and Van Devanter joining opinion); Krichman v. United States, 256 U.S. 363 (1921) (reversing bribery conviction of railroad porter because porter was not acting on behalf of the United States in any official capacity, with McReynolds and Van Devanter joining opinion); Brown v. United States, 256 U.S. 335 (1921) (reversing murder conviction because of improper jury instruction, with McReynolds and Van Devanter joining opinion); Ex Parte Hudgings, 249 U.S. 378 (1919) (holding that court could adjudge a witness guilty of contempt and imprison him solely because in the court's opinion he was willfully refusing to testify truthfully, with McReynolds and Van Devanter joining opinion); United States v. Weitzel, 246 U.S. 533 (1918) (upholding demurrer to criminal indictment against bank receiver for bribery because, as an officer of United States, he could not be tried under the statute in question, with McReynolds and Van Devanter joining opinion); Omaechevarria v. Idaho, 246 U.S. 343, 353 (1918) (McReynolds and Van Devanter dissent from opinion affirming conviction under state law forbidding the grazing of cattle and sheep on herding lands); United States v. Oppenheimer, 242 U.S. 85 (1916) (affirming dismissal of an indictment against defendant who concealed assets from trustee in bankruptcy on the basis of res judicata, with McReynolds and Van Devanter joining opinion); Abbott v. Brown, 241 U.S. 606 (1916) (granting habeas corpus petition to defendant convicted of a criminal act, but later retried and 
acquitted and not released, with Van Devanter joining opinion) (McReynolds takes no part).

${ }^{194}$ See Isaiah Berlin, Four Essays on Liberty 122-31 (1969).

${ }^{195}$ See United States v. Carolene Products Co., 304 U.S. 144, 152 n.4 (1938).

196261 U.S. 525.

${ }^{197}$ Id. at 556 ("[I]f women require a minimum wage to preserve their morals men require it to preserve their honesty.").

${ }^{198}$ See Abrams v. United States, 250 U.S. 616 (1919); Debs v. United States, 249

U.S. 211 (1919); Frohwerk v. United States, 249 U.S. 204 (1919); Schenck v. United States, 249 U.S. 47 (1919).

${ }^{199}$ Hammerschmidt v. United States, 265 U.S. 182 (1924).

200268 U.S. 652 (1925).

201 Id. at 666.

${ }^{202}$ Whitney v. California, 274 U.S. 357 (1927).

${ }^{203}$ Fiske v. Kansas, 274 U.S. 380 (1927).

${ }^{204}$ Stromberg v. California, 283 U.S. 359, 370 (1931) (McReynolds, J., dissenting).

${ }^{205}$ Id. at 371 (Butler, J., dissenting).

${ }^{206}$ Id. at 360.

${ }^{207}$ See Bond, supra note 19, at 53-54.

${ }^{208} 283$ U.S. 697, 723 (1931) (Butler, Van Devanter, McReynolds, and Sutherland, JJ., dissenting).

${ }^{209} 297$ U.S. 233 (1936).

${ }^{210}$ Herndon v. Lowry, 301 U.S. 242, 264 (1937) (Van Devanter, McReynolds, Sutherland, and Butler, JJ., dissenting).

${ }^{211}$ De Jonge v. Oregon, 299 U.S. 353, 365 (1937).

212310 U.S. 586 (1940).

${ }^{213}$ Cantwell v. Connecticut, 310 U.S. 296 (1940).

${ }^{214}$ Lovell v. City of Griffin, 303 U.S. 444 (1938).

${ }^{215}$ See Bond, supra note 19, at 53-54.

216262 U.S. 390 (1923); see also Bartels v. Iowa, 262 U.S. 404 (1923).

${ }^{217} 273$ U.S. 284 (1927).

${ }^{218} 268$ U.S. 510 (1925); see William G. Ross, Forging New Freedoms: Nativism, Education, and the Constitution, 1917-1927 (1994).

${ }^{219}$ NAACP v. Alabama ex rel. Patterson, 357 U.S. 449 (1958).

${ }^{220}$ New York ex rel. Bryant v. Zimmerman, 278 U.S. 63, 75-76 (1928).

${ }^{221}$ See, e.g., Toyota v. United States, 268 U.S. 402 (1925); United States v. Thind, 261 U.S. 204 (1923); Yamashita v. Hinkle, 260 U.S. 199 (1922); Ozawa v. United States, 260 U.S. 178 (1922).

222 United States v. Schwimmer, 279 U.S. 644 (1929).

${ }^{223}$ See United States v. MacIntosh, 283 U.S. 605 (1931).

224 See United States v. Bland, 283 U.S. 636 (1931).

${ }^{225} 239$ U.S. 3 (1915).

226253 U.S. 90 (1920).

227253 U.S. 454 (1920).

${ }^{228}$ Id. at 457; see also $\mathrm{Ng}$ Fung Ho v. White, 259 U.S. 276, 281-85 (1922).

229268 U.S. 336 (1925).

230307 U.S. 325 (1939). 
231291 U.S. 559 (1934).

${ }^{232}$ Id. at 560-61, 563. See also United States v. Manzi, 276 U.S. 463, 467 (1928) (Sutherland, J., dissenting from opinion upholding denial of citizenship to widow of alien who died after declaring his intention to become a citizen but before completing naturalization).

${ }^{233} 241$ U.S. 73 (1916).

${ }^{24}$ Id. at 75-76, 79 (discussing 34 Stat. 1246 (1907)).

${ }^{235}$ See Terrace v. Thompson, 263 U.S. 197 (1923) (McReynolds voting to dismiss the case on justiciability grounds and Sutherland not participating); Porterfield v. Webb, 263 U.S. 225 (1923) (same); Webb v. O'Brien, 263 U.S. 313 (1923) (same); Frick v. Webb, 263 U.S. 326 (1923) (same). See also Cockrill v. California, 268 U.S. 258 (1925) (Van Devanter, McReynolds, and Sutherland joining Butler's opinion for the Court, affirming conviction under the California Alien Land Law). But see Morrison v. California, 291 U.S. 82 (1934) (all Four Horsemen joining the Court's opinion reversing conviction for conspiracy to violate California Alien Land Law).

236239 U.S. 33 (1915).

${ }^{237}$ Id. at 35, 43. McReynolds dissented on Eleventh Amendment grounds, but stated "[ $t$ ]hat the challenged act is invalid I think admits of no serious doubt." Id. at 43-44 (McReynolds, J., dissenting).

238265 U.S. 332 (1924).

2399 U.S. 123 (1928).

${ }^{240}$ Id. at 124-25, 130; see also Morrison v. California, 291 U.S. 82 (1934) (all Four Horsemen joining the Court's opinion reversing the conviction of a farmer of Japanese descent for violation of California's Alien Land Law).

$2+1271$ U.S. 500 (1926).

${ }^{242}$ Id. at 524, 525 . 


$$
\text { . }
$$

